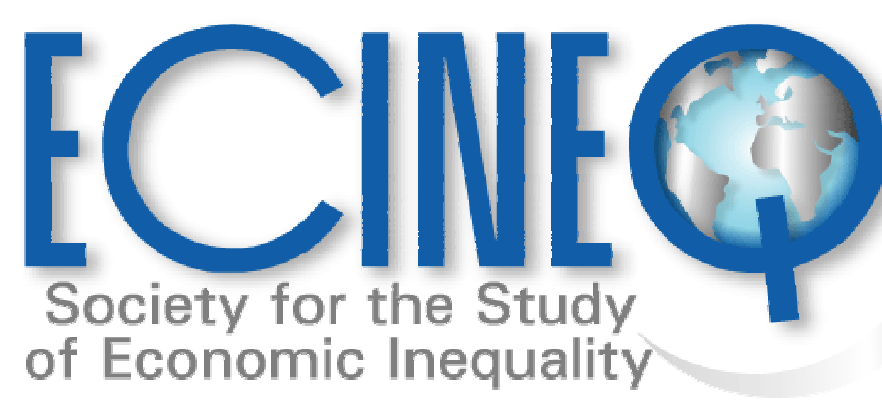

\author{
Working Paper Series
}

Channels of inequality of opportunity: The role of education and occupation in Europe

Juan C. Palomino

Gustavo A. Marrero

Juan G. Rodríguez

ECINEQ WP 2016 - 411 


\title{
Channels of inequality of opportunity: The role of education and occupation in Europe*
}

\author{
Juan C. Palomino \\ Universidad Complutense de Madrid, EQUALITAS and CEDESOG, Spain
}

Gustavo A. Marrero

Universidad de la Laguna, EQUALITAS and CEDESOG, Spain

Juan G. Rodríguez

Universidad Complutense de Madrid, EQUALITAS and CEDESOG, Spain

\begin{abstract}
This paper studies the contribution of individual education and occupation to individual opportunity in Europe. Although the differences in inequality of opportunity (IO) among European countries are significant, no systematic approach has yet been proposed to analyse the channels through which different individual circumstances turn into different income levels. Here, we propose a simple two-step method to quantify the contribution to IO of individual education and occupation across Europe in 2004 and 2010. We find that the level of education channels up to $30 \%$ of total IO, with important differences across Europe but no clear patterns of change over time. Moreover, we observe a negative correlation between the share of IO channelled through education and the share of the population with tertiary education. Once education is taken into account, the occupational category of individuals explains less than $5 \%$ of total IO in most European countries.
\end{abstract}

Keywords: Inequality of opportunity, education, occupation, Europe.

JEL Classification: D63, I24, J24, 052.

${ }^{*}$ We would like to thank Eduardo Gonzalo-Almorox, Gabriela Sicilia, and the participants at the 34th IARIW conference in Dresden and at the 28th EALE conference in Ghent for valuable comments and suggestions. The usual disclaimer applies. The authors acknowledge the financial support of the Ministerio de Economía y Competitividad of Spain (Palomino and Rodríguez through project ECO2013-46516-C4-4-R and Marrero through project ECO2013-48884-C3-3-P), from Comunidad de Madrid (Spain) under project S2015/HUM-3416-DEPOPORCM and from Fundacíon Caja Canarias (Spain). The authors are also grateful for microdata access provided by the European Comission (Eurostat) through the research project 221/2014EU-SILC.

†Contact details. J.C. Palomino: Tel. +34 916710 784; E-mail: juancpal@ucm.es. G.A. Marrero: Tel. +34 922277 798; E-mail: gmarrero@ull.es. J.G. Rodríguez: Tel. +34 913942 515; E-mail: juangabr@ucm.es. 


\section{Introduction}

There seems to be a social and academic consensus in considering inequality caused by initial socioeconomic factors as unfair, for it is thought to be out of the responsability sphere of the individual. In line with this perception -and led by the pioneering interdisciplinary work of Roemer (1993)- economists have started in the last two decades to shift the focus from overall inequality to the so-called 'inequality of opportunity' (IO), trying precisely to measure the extent of that 'unfair' inequality. The concept of (in)equality of opportunity has come to play a central role not only in the academic context but also in the political debate.

In one of its most common formal definitions, equality of opportunity demands that individual characteristics or 'circumstances', upon which the individual has no control (such as family background, race or place of birth) do not affect the outcome (income, welfare, health) obtained by the individual [Rawls (1971), Sen (1980), Roemer (1993), Fleurbaey (2008)]. If this does not hold, the existing IO would be unjust, and public intervention should help to 'level the playing field' [Roemer et al. (2003)]. ${ }^{1}$

So far, most of the existing literature on equality -or inequality- of opportunity has endeavoured in the development of different approaches to measure IO and its comparison across countries. $^{2}$ Albeit crucial for any ulterior analysis, these works have limited interest for any applied policy decision, since they provide little information about the mechanisms that channel IO, i.e., the factors that make the initial conditions relevant for future income.

Then, which -and how important- are these mechanisms? How do different individual initial conditions turn into different future levels of income? A priori, one would think of two main channels, namely, the education system and the allocation in the labor market. On the one hand, education has widely been recognised as a key element in the economic production func-

\footnotetext{
${ }^{1}$ In addition, recent findings point out that IO would be also inefficient and negative for economic growth, as it favors the misallocation of talent and human capital [Marrero and Rodríguez (2013 and 2016); Bradbury and Triest (2016)]

${ }^{2}$ See, for example, Lefranc et al. (2008), Rodríguez (2008), Checchi and Peragine (2010), Ferreira and Gignoux (2011), Marrero and Rodríguez (2012), Li Donni et al. (2015) or Brzezinski (2015).
} 
tion going back to the works of Becker (1964) and Lucas (1988), and its effect on the acquisition and distribution of earnings has also been established in the literature [Psacharopoulos (1994), Card (1999), Trostel et al. (2002), Lemieux (2006) or Ingram and Neumann (2006)]. On the other hand, the connection between the individual educational attainment and parental background has been widely analysed [Gamboa and Waltenberg (2012) or Ferreira and Gignoux (2014)], and there is also evidence that the educational level mediates a relevant share of the intergenerational income persistence [Eide and Showalter (1999), Palomino et al. (2014) and Chetty et al. (2014)]. Analogously, the occupation -industry specific human capital- of the individual has also been shown to impact the economic achievement [Sullivan (2010)] and is in turn connected with the family background. ${ }^{3}$

It seems then that the education and occupation of the individual are tied to both ends of (in)equality of opportunity: the initial conditions and the final outcome. Different circumstances in childhood may lead to different levels of education and different occupational categories, which in turn contribute to generate different economic outcomes in the adulthood. Data on these potentially important mediators the level of education and the occupational category- are frequently included in databases and could be exploited.

The analysis of these two possible channels of IO, however, is not straightforward. First, both channels are closely linked, and the education system is expected to strongly condition the final allocation in the labor market. Second, some of the possible educational and occupational variables are subtle and hard to analyse, like school quality, job connections or access to social networks. The first problem can be tackled if the analysis method follows the natural order of both factors in the life cyle, thus considering education as a prior mediator that influences occupation, and assuming that -generally- formal education is not influenced by the occupational category. ${ }^{4}$ As for the second problem, even though the absence of a complete set of education and occupation variables should make us concious of the impossibility of

\footnotetext{
${ }^{3}$ Parental connections when looking for a job and nepotism -which limit the scope of labor market competition- are relevant to explain the final allocation for a particular position [Pérez-González (2006)].

${ }^{4}$ As explained in Section 2 below, in our proposed methodology the channeling role of occupation is measured controlling for education first.
} 
measuring their full channeling role, it should not prevent us from attempting the analysis.

Acknowledging these shortcomings, this paper develops a simple strategy to estimate how much of the IO in income is channelled through the educational level and the occupational category of the individual in Europe. ${ }^{5}$ In a first stage, without loss of generality, we apply the ex-ante approach to estimate the 'smoothed income distribution' (i.e., the income conditioned to individual circumstances) and compute IO in the acquisition of income, following Ferreira and Gignoux (2011) and Checchi and Peragine (2010). We have used the ex-ante approach for comparability reasons with recent studies estimating IO for EU countries [Marrero and Rodríguez (2012), Brzezinski (2015), Checchi et al. (2016)], but the methodology can be also applied to the ex-post approach [Checchi and Peragine (2010)]. In the second stage, using again the ex-ante approach, we condition the smoothed income distribution to the education of the individual, and the residual of this last regression to the occupation of the individual; finally, we estimate the IO associated to each component, isolating in this way the shares of IO transmitted through individual education, occupation (once controlled for education) and the final residual component.

Exploiting the two special modules on intergenerational transmission of poverty in the EUSILC database (waves 2005 and 2011), we apply our methodology for 26 European countries in both waves. Even though only the level of education is used to analyse the role of the education system (there is no information on school quality or school socioeconomic status), we find education to be a relevant channel of IO. First, the level of education mediates the $15 \%$ of IO or more in ten European countries in 2004 and 2010 (more than $30 \%$ of IO in Portugal and Luxembourg in 2010). Second, there is no clear geographical pattern. For example, the range of the educational channel of IO in Central Europe goes from 8.4\% (Germany) to $31.0 \%$ (Luxembourg) in 2010, while, for the same year, ranges from $7.9 \%$ (Estonia) to $24.0 \%$ (Hungary) in Eastern Europe. Third, there is not a general tendency in the variation of the educational share of IO between 2004 and 2010: 9 out of 26 European countries experience

\footnotetext{
${ }^{5}$ This method can be applied to other outcome variables, not necessarily income.
} 
an increase of their educational share of IO, 11 remain stable and 6 decrease. In addition, we find that the importance of education as a channel for IO is negatively correlated with the share of the population that attains tertiary levels of education. This result points at a potential social externality of expanding access to education: the provision of opportunities. It seems that, in countries where a greater part of the population can access higher levels of education, the connection between background circumstances, levels of education and adult income is weaker.

With respect to the occupation channel of IO, it is associated with only between $1 \%$ and $5 \%$ of IO in most countries, once the education channel has been discounted. Nevertheless, the range across countries is relatively large, with Netherlands in 2004 (0.93\%) and Cyprus in $2010(8.24 \%)$ as the countries where occupation mediates less and most, respectively. For the occupational share of IO, the geographical pattern in Europe is not clear and the variation between 2004 and 2010 does not have a well-defined tendency.

The rest of the paper is structured as follows. In Section 2, we present the methodology to measure the channels of IO. Section 3 details our choices and treatment of the EU-SILC database and comments on the results of our primary regressions. Section 4 presents our estimates of overall inequality and IO across Europe in 2004 and 2010, while section 5 displays our findings for the educational and occupational channels. In Section 6, we discuss the implications of the correlation between the educational IO channel and the levels of attained education. Finally, Section 7 concludes.

\section{Methodology}

We present a two-step procedure to estimate the importance of the educational and occupational channels in determining IO. Among the existing approaches to estimate IO, we adopt the ex-ante parametric approach [Checchi and Peragine (2010), Ferreira and Gignoux (2011)] in the first step, for it allows us to compare our IO estimates with existing estimations of IO for Europe. In the second step, we use the smoothed income distribution, that incorporates 
all differences in individual income attributed to observed circumstances, and decompose it to estimate the shares of IO that are associated with the education attained and the occupational category of individuals.

\subsection{Step 1: Computing inequality of opportunity}

The alternative methods to estimate IO are classified into two main approaches, the ex-post and the ex-ante [Fleurbaey (2008)]. The ex-post approach states that there is equality of opportunity if all individuals who exert the same degree of effort obtain the same outcome, while the ex-ante refers to equality of opportunity if all individuals face the same set of opportunities regardless of their circumstances. As mentioned above, and although we outline in the Appendix the extension of our strategy to a version of the ex-post approach, we focus here on the ex-ante approach for comparability reasons. ${ }^{6}$

Assume that the income $y_{i}$ of the individual $i \in\{1, \ldots, N\}$ is a function of her effort $e_{i}$ and her set of circumstances $C_{i}$, so that $y_{i}=f\left(C_{i}, e_{i}\right)$. Circumstances are assumed to be exogenous by definition. Effort however is likely to be influenced, among other factors, by personal circumstances. Accordingly, individual income may also be written as $y_{i}=f\left(C_{i}, e_{i}\left(C_{i}\right)\right)$. Suppose the population is partitioned into $T$ mutually exclusive and exhaustive types denoted by $\epsilon=J_{1}, \ldots, J_{T}$, where all individuals of a given type $t$ share the same circumstances. Then, within each type, and assuming all circumstances have been accounted for, only effort $e_{i}$ would determine the income of each individual $i$. Equality of opportunity, then, is achieved when the individual's income is independent of her circumstances. Strictly speaking, this would demand that the following condition holds true:

$$
F^{t}(y)=F^{m}(y), \forall t, m,
$$

\footnotetext{
${ }^{6}$ Fleurbaey and Peragine (2013) and Ramos and Van de Gaer (2012) discuss the formal compatibility and practical implications of both approaches.
} 
where $F^{t}(y)$ denotes the income distribution for individuals of type $t$. In this case, no set of circumstances offers a better opportunity set of incomes than any other, thus abiding the condition for ex-ante equality of opportunity (what Lefranc et al. (2008) call 'strong equality of opportunity'). On the contrary, if one distribution dominates the other, this would offer unambiguous evidence against equality of opportunity. Unfortunately, relying on stochastic dominance is generally not guaranteed to rule one way or the other. Distributions can be significantly different and yet cross each other, in which case it is unclear whether one type is better off than the other [Atkinson (1970)].

To break potential ties, a practical alternative is to use an inequality index able to decompose income inequality into inequality within types and inequality between types, focusing for that purpose on a specific moment of each type distribution, i.e., the mean or a parametric estimate of income conditioned to circumstances. Differences in income within types cannot be attributed to circumstances, while inequality between types can be used as a measure of $\mathrm{IO}^{7}$

Among all the possible inequality indices that fulfill the basic principles found in the literature on inequality (progressive transfers, symmetry, scale invariance and replication of the population), only those of the Generalized Entropy class are additively decomposable into a between-group and a within-group component [Bourguignon (1979) and Shorrocks (1980)]. ${ }^{8}$ We use the Mean Logarithmic Deviation (MLD) because it belongs to the Generalized Entropy class, has a path-independent decomposition [Foster and Shneyerov (2000)], and uses weights based on the groups' population shares. For an income distribution $y$, with mean $\bar{y}$, the MLD is defined as:

\footnotetext{
${ }^{7}$ Since it is impossible to observe all individual circumstances in practice, this estimate of IO is interpreted as a lower bound. Between-types inequality can only increase if the number of observed circumstances increases and the population is partitioned into more types. This problem is pervasive in the literature on inequality of opportunity. For a different approach, where types are seen as latent classes, see Li Donni et al. (2015).

${ }^{8}$ The broadly used Gini coefficient is not additively decomposable. In the case that type income ranges overlap, which occurs in our case, this measure is decomposable in three terms: a between-group component, a within-group component and a residual. The problem here is how to assign the last term to the between-group and within-group components.
} 


$$
I_{M L D}(y)=\frac{1}{n} \sum_{i=1}^{n} \ln \left(\frac{\bar{y}}{y_{i}}\right)
$$

The decomposition of this index into between-group and within-group inequality components solves:

$$
I_{M L D}(y)=\sum_{t=1}^{T} p_{t} \ln \left(\frac{\bar{y}}{\overline{y_{t}}}\right)+\sum_{t=1}^{T} p_{t} I_{M L D}\left(y^{t}\right)
$$

where $p_{t}$ is the population share of each group $t, \bar{y}$ is the overall population mean and $\bar{y}_{t}$ is the mean value for each group $t$. The first term of Eq. (3) represents inequality between groups of the population (types) while the second component represents inequality within those groups. In an equivalent expression, the 'between' component of inequality can be obtained as the inequality of a 'smoothed distribution' $\mu$ in which all individuals from each group $t$ have the same circumstances and the same value of $y_{i}^{t}=y_{i} \mid C_{i}^{t}$, while the within component is the inequality of a 'standardized distribution' $(\phi)$ in which all differences across groups have been eliminated and only differences within groups remain [Ferreira and Gignoux (2011), Checchi and Peragine (2010)]:

$$
I_{M L D}(y)=I_{M L D}(\mu)+I_{M L D}(\phi) .
$$

In this framework, a non-parametric approach would estimate the income means for each predefined type without any assumption on the relation of income and circumstances. However, when the number of circumstances is high, the number of observations in some of the types may become too low to obtain accurate non-parametric estimates. ${ }^{9}$ A parametric approach, on the other hand, assumes a log-linear relationship between circumstances and income and orthogonality of circumstances and the error term, but it allows to estimate the income con-

\footnotetext{
${ }^{9}$ The non-parametric approach has been used, nevertheless, in methods that focus on ordinal methods of IO measurement using dominance criteria [Lefranc et al. (2008); Rodríguez (2008)].
} 
ditioned to circumstances for all types even when the number of observations per type is relatively low [Bourguignon et al. (2007); Ferreira and Gignoux (2011)]. Given the size of our sample and the relatively high number of circumstances that we have in the database (see Section 3), we adopt the parametric approach and estimate the following log-linearized equation:

$$
\ln y_{i}=C_{i} \psi+\varepsilon_{i}
$$

The estimated OLS coefficients $\hat{\psi}$ are then used to obtain the smoothed income distribution in which all individuals belonging to the same type (i.e., sharing the same set of circumstances $C_{i}$ ) are assigned the same income as follows:

$$
\tilde{\mu}_{i}=\exp \left[C_{i} \hat{\psi}\right]
$$

where $\tilde{\mu}_{i}$ is the income predicted for all individuals $i$ conditioning on their set of circumstances. Accordingly, IO -inequality between types- is computed by applying $I_{M L D}$ to the 'smoothed distribution':

$$
I O=I_{M L D}(\tilde{\mu})
$$

The within component can, in a parametric framework, be expressed as the inequality of the standardized distribution $\phi$, which is obtained by assigning all individuals the same average level of the conditioning variables $\overline{C_{i}}$, plus the individual variability not captured by circumstances [Ferreira and Gignoux (2011)]:

$$
\tilde{\phi}_{i}=\exp \left[\overline{C_{i}} \hat{\psi}+\hat{\varepsilon}_{i}\right]
$$

This distribution $\tilde{\phi}$ eliminates all differences attributed to circumstances, but keeps within- 
type variability through the term $\hat{\varepsilon}_{i}$. Inequality in this distribution can be expressed as:

$$
I R=I_{M L D}(\tilde{\phi})
$$

where $I R$ thus represents the residual or complementary share of overall inequality not explained by the observed set of circumstances. ${ }^{10}$ Overall inequality $I$, then, can be decomposed in IO and IR, in a version of equation (4) that uses the parametric estimates of the distributions:

$$
\underbrace{I_{M L D}(y)}_{I}=\underbrace{I_{M L D}(\tilde{\mu})}_{I O}+\underbrace{I_{M L D}(\tilde{\phi})}_{I R}
$$

\subsection{Step 2. The educational and occupational channels}

From the smoothed distribution calculated in the previous step, we know that the part of total income for individual $i$ belonging to type $t$ that is explained by her observed circumstances $C_{i}, y_{i}{ }^{C}$, is given by:

$$
y_{i}{ }^{C}=y_{i} \mid C_{i}=\tilde{\mu}_{i} .
$$

However, in general, circumstances do not directly convert into future income. There exists a set $Z$ of intermediate variables, like the education or the job category attained by the individual, which are conditioned by individual circumstances and that, in turn, are the factors affecting the income of the individual. Accordingly, the component of income explained by observed circumstances can then be expressed as:

\footnotetext{
${ }^{10}$ Note that $\tilde{\phi}^{i}=\exp \left[\overline{C_{i}} \hat{\psi}+\hat{\varepsilon}_{i}\right]$ is equivalent to: $\exp \left[\overline{C_{i}} \hat{\psi}\right] \cdot \exp \left[\hat{\varepsilon}_{i}\right]$. Applying MLD to this last expression, and given that $\exp \left[\bar{C}_{i} \hat{\psi}\right]$ is constant, it is true -recall that the MLD index is scale invariant- that $I_{M L D}(\tilde{\phi})=$ $I_{M L D}\left(\exp \left[\hat{\varepsilon}_{i}\right]\right)$. Thus, in a parametric framework using the MLD inequality measure, the within inequality component boils down to the MLD of the distribution of the residual term from the parametric regression.
} 


$$
y_{i}^{C}=f\left(Z_{i}, \nu_{i}\right)
$$

where $Z_{i}$ is the set of the observed intermediate variables, and $\nu_{i}$ a term that includes all the unobserved mediating variables and the random component of income of individual $i .^{11}$

First, we consider that the set of intermediate variables consists in the levels of individual education $(E)$, i.e., $Z_{i}=E_{i}$. Then, in accordance with Eq. (12) we can assume:

$$
\ln y_{i}^{C}=E_{i} \eta+\nu_{i}
$$

The OLS estimated coefficients of this regression can be applied to the values of $E_{i}$ to obtain the distribution of expected income -conditioned to circumstances- predicted by personal education; i.e., $y_{i}^{C, E D U}=\exp \left[E_{i} \hat{\eta}\right]$, where the estimates of $\eta$ include not only the direct effect of education $E$ on income conditioned to circumstances $y^{C}$, but also the indirect effect.

In Section 2.1., we obtained IO as the inequality between types, using the smoothed distribution. In this step, we will in turn decompose $I_{M L D}\left(y^{C}\right)$ into its own 'between' and 'within' components, the groups being now formed by people with the same amount of individual education. While $y_{i}^{C}$ has the same value for all individuals with the same set of circumstances $C_{i}$, now $y_{i} C, E D U$ has the same value for all individuals with the same education (and the same circumstances). Inequality in this 'oversmoothed' distribution is the income inequality 'between' the groups of people with different education, conditioning to their circumstances. In other words, it is the inequality of opportunity 'channelled' by the level of individual education.

\footnotetext{
${ }^{11}$ Analogously, it could be argued that effort, or at least part of it, would be transformed into income through other mediating factors $H$. Education, for example, could also be a mediator between effort and income (people who exert more effort achieve a higher level of education that will increase their income). We could express the component of income not explained by observed circumstances (from Eq. (5)) as $y_{i}^{\bar{C}}=\exp \left[\varepsilon_{i}\right]=f\left(H_{i}, \Omega_{i}\right)$, where $H_{i}$ collects observed mediators between effort and income, and $\Omega_{i}$ includes the effect on income of unobserved mediators and a random component. Unfortunately, although our term $I R$ is sometimes called 'inequality of effort' in the literature and could be considered an upper bound of such inequality, we must not forget that $\varepsilon_{i}$ includes both the effect of effort and of unobserved circumstances. We are then unable to isolate the effect of effort, which prevents us from going further into the analysis of the residual component of income.
} 
The inequality of the residual $y_{i}^{C, \overline{E D U}}$ is then interpreted as the inequality of $y_{i}^{C}$ 'within' the groups of people with the same amount of education. Inequality in the distribution of the residual income $y_{i}^{C, \overline{E D U}}=\exp \left[\hat{\nu}_{i}\right]$ is equivalent to a standardized distribution obtained by applying $\hat{\eta}$ to a constant average level educational level $\bar{E}$ and adding the residual term. Both distributions differ only in a change of scale and would have the same level of inequality using $\operatorname{MLD}$, since $I_{M L D}\left(\exp \left[\bar{E}_{i} \hat{\eta}_{i}+\hat{\nu}_{i}\right]\right)=I_{M L D}\left(\exp \left[\hat{\nu}_{i}\right]\right)$. Thus, the decomposition is:

$$
\underbrace{I_{M L D}\left(y^{C}\right)}_{I O}=\underbrace{I_{M L D}\left(y^{C, E D U}\right)}_{I O_{E D U}}+\underbrace{I_{M L D}\left(y^{C, \overline{E D U}}\right)}_{I O_{\overline{E D U}}},
$$

where $I O_{E D U}$ represents the part of IO that is channelled through the educational level, and the residual term $I O_{\overline{E D U}}$ measures the amount not mediated by education. For instance, if the individual educational level predicts the income vector $y^{C}$ perfectly, we will have that $y_{i}^{C, E D U}=y_{i}^{C}$ for all $i$, and all the $\mathrm{IO}$ in income would be mediated by the attained education, i.e., $I O=I O_{E D U}$, and $I O_{\overline{E D U}}$ would be zero. The inverse would occur if all variability in $y^{C}$ was captured by the error term $\nu$ in Eq.(13) and nothing by the estimated $E \hat{\eta}$.

The relative share of IO mediated by the level of education (including both the direct and potential indirect effects), denoted by $I O_{E D U}^{R}$ is given by:

$$
I O_{E D U}^{R}=\frac{I_{M L D}\left(y_{i}{ }^{C, E D U}\right)}{I_{M L D}\left(y_{i}^{C}\right)}=\frac{I O_{E D U}}{I O} .
$$

where $0 \leq I O_{E D U}^{R} \leq 1$ by construction. ${ }^{12}$

However, the educational level is not the only possible channel of IO. The component of $y_{i}{ }^{C}$ not channelled by education, denoted by $y_{i}^{C, \overline{E D U}}$ could be transmitted by other variables. In particular, the occupational category of the individual is another reasonable candidate -also available in our database for Europe- that could channel IO. Different occupational categories

\footnotetext{
${ }^{12}$ Note that our strategy could be applied to the version of the ex-post approach proposed by Checchi and Peragine (2010). See Appendix I.
} 
may be related to circumstances (e.g. parental occupation) and may also be related to different salaries or economic advantages. Then,

$$
\ln y_{i}^{C, \overline{E D U}}=O_{i} \kappa+\xi_{i}
$$

where $O$ represents the occupational category of the individual and $\xi$ represents the remaining part of the circumstance-conditioned income $y^{C}$ not explained by the educational level nor the occupational category. By using only the part of $y_{i}^{C}$ not attributed to the level of education $\left(y_{i}^{C, \overline{E D U}}\right)$ we measure the channelling role of the other possible mediating variables -i.e. occupation- free of the interaction with the education channel, and $I O_{O C C}$ will be net of the influence of education. Formally, this does prevent $I O_{E D U}$ from including the joint effect of education and the variable analysed (occupation) if they were correlated. However, the fact that the attained educational level temporarily precedes the occupational category of the individual discards that possibility. In other words, the order of the IO decomposition follows the natural order in which these variables generally transmit opportunities: first education, then occupation.

We can thus obtain the distribution of $y_{i}{ }^{C}$ predicted by occupation, once the educational channel has been accounted for, $y_{i}{ }^{C, O C C}=\exp \left[O_{i} \hat{\kappa}\right]$ and the residual $y_{i}{ }^{C, O T H}=\exp \left[\hat{\xi}_{i}\right]$, which represents the part of $y_{i}{ }^{C}$ channelled through variables other than education and occupation.

Finally, the relative share of IO mediated by the level of occupation (net of the educational channel), denoted by $I O_{O C C}^{R}$, is given by:

$$
I O_{O C C}^{R}=\frac{I_{M L D}\left(y_{i}{ }^{C, O C C}\right)}{I_{M L D}\left(y_{i}{ }^{C}\right)}=\frac{I O_{O C C}}{I O},
$$

where $0 \leq I O_{O C C}^{R} \leq 1$ by construction.

Using $y_{i}^{C}$ from Eq.(5), Eq.(6) and Eq.(11), and applying Eq.(13) and Eq.(16), the steps in the decomposition of IO could be recapitulated in: 


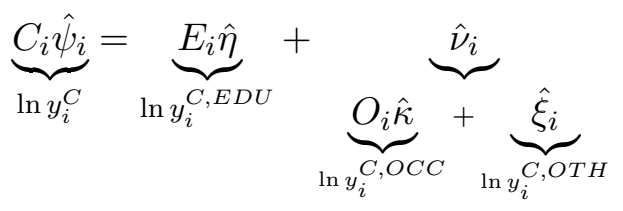

and that, as show above: ${ }^{13}$

$$
I_{M L D}\left(y^{C}\right)=I_{M L D}\left(y^{C, E D U}\right)+I_{M L D}\left(y^{C, O C C}\right)+I_{M L D}\left(y^{C, O T H}\right)
$$

where $I_{M L D}\left(y^{C, O T H}\right)$ is the inequality of opportunity not associated with education nor with occupation. Finally, dividing the above expression by $I_{M L D}\left(y^{C}\right)=I O$ we obtain,

$$
1=I O_{E D U}^{R}+I O_{O C C}^{R}+I O_{O T H}^{R},
$$

where $I O_{E D U}^{R}$ is the share of IO channelled by the educational level, $I O_{O C C}^{R}$ the share of IO channelled by the occupational category (net of education) and $I O_{O T H}^{R}$ the share of IO not channelled by either of the two variables considered.

This sequential decomposition process could continue and be applied to as many channels as we have information about, as long as the decomposition follows the order in which these channels come into play in the life of the individual. Although it requires the use of the decomposable MLD index, our method achieves a complete decomposition of IO in the considered channels and the residual 'unchannelled' IO.

In the following sections we describe how we use information about the individual level of education and the occupational category to apply our strategy and measure their IO channeling role for 26 European countries in 2004 and 2010.

\footnotetext{
${ }^{13}$ Note that, being a logarithmic addition, Eq.(18) is equivalent to $y_{i}^{C}=y_{i}^{C, E D U} \cdot y_{i}^{C, O C C} \cdot y_{i}^{C, O T H}$.
} 


\section{Database and primary regressions}

We use data from the European Statistics of Income and Living Conditions database (EUSILC), which encompasses homogeneous surveys on living conditions implemented by the national institutes of statistics under the coordination of Eurostat. Collected data contains information on a wide range of items, including income, education and occupation of all individuals in each household. Some variables are also collected or aggregated at the household level.

In its 2005 and 2011 waves, the living conditions survey included an additional questionnaire aimed to gather information about the economic and social background of the respondents. Thus, the "Intergenerational Transmission of Poverty" module in 2005 and the "Intergenerational Transmission of Disadvantages" module in 2011 include questions about parental education and occupation, and about the financial situation of the household during the respondents' childhood. These items upon which the individual has no control are circumstances, which makes them suitable for an IO analysis [Roemer (2009)].

Our particular set of circumstances, which is very similar to the one used in Marrero and Rodríguez (2012) for comparability reasons, comprises the highest level of parental education attained from both father and mother, father's occupational category (since mother's occupation is missing in several countries, we dropped it from the set of circumstances) and the perceived financial struggle in the household when the respondent was about 14 years old. The educational level of the father is coded slightly differently in each wave. ${ }^{14}$ In order to have the most homogenous set of circumstances possible, we have recoded the 2005 parental educational levels into the 2011 equivalents, coding 'less than primary' as 'No education',

\footnotetext{
${ }^{14}$ In the 2005 module, there were 5 different categories: less than primary, which includes no education and education below the primary level (1997 International Standard Classification of Education (ISCED) level 0 ); primary education (ISCED 1), lower secondary education (ISCED 2), upper secondary education (ISCED 3 ), post-secondary non-tertiary education (ISCED 4), and first stage and second stage of tertiary education (ISCED 5 and 6). In 2011, however, the parental questionnaire only has four educational levels: 'No education', 'Low education' (ISCED levels 0, 1 and 2), 'Middle Education' (ISCED levels 3 and 4) and 'High Education' (ISCED levels 5 and 6). Parental education from both father and mother is provided for all individuals in all countries in the sample.
} 
grouping the ISCED levels 1 and 2 (primary and secondary) into 'Low Education', and levels 3 and 4 into 'Middle Education'. The occupational circumstances of the father correspond to the broad one-digit groups from the International Standard Classification of Occupation (ISCO-88). ${ }^{15}$

The question referring to the financial difficulties perceived by the respondent during childhood was slightly changed in the 2011 module. In 2005, the question referred to 'how often did the household have financial difficulties', where in 2011 two different questions address the difficulty to 'make ends meet' and the 'financial situation of the household'. Again for the sake of homogeneity across waves, we have chosen to include only the latter question and have also recoded the answers in five categories instead of six like in the 2005 questionnaire. ${ }^{16}$ Finally, we complete our set of circumstances with two other individual variables from the main survey questionnaire: gender of the individual and the country of birth (local, from another EU country or from another country outside the EU).

We use "equivalent disposable household income" as the proxy for the economic advantage of the individual; income from 2010 (2011 wave) has been converted to 2004 (2005 wave) terms using the Harmonised Consumer Price Index published by Eurostat. Our sample is restricted to only household heads, the head being the person of the household with the highest individual labour income. ${ }^{17}$ In order to exclude incomes obtained at the tails of the

\footnotetext{
${ }^{15}$ Categories include: managerial, professional, technician, clerical, sales, skilled agricultural, craft trade, machine operation, elementary occupation and armed/military occupation. Father's occupation is available for all countries except for Sweden, where that information is missing for around $75 \%$ of the sample used in both waves. Note that we have also included 'unemployed' as occupational category for those individuals who were unemployed, not disabled to work nor retired, and for which the occupational category was not coded.

${ }^{16}$ In the 2011 module, the perceived financial situation could be considered very bad, bad, moderately bad, moderately good, good and very good. We have chosen to melt the two middle categories in one single 'moderate' category, in order to have the same number of categories in both waves. The analogous answers to the 2005 question about how often did the household had financial difficulties were: 'most of the time', 'often', 'occasionally', 'rarely' and 'never'. Also note that, while in 2011 this item appears in all countries' questionnaires, in 2005 this question was not included in Austria, Germany, Greece, France and Portugal.

${ }^{17}$ The equivalence scale used by Eurostat is $1+0.5 *\left(H M_{14}-1\right)+0.3 * H M_{13}$, where $H M_{14}$ refers to the individuals in the house who are fourteen or older, while $H M_{13}$ refers to the individuals in the house who are thirteen or younger. Although we considered using individual labour income as the proxy variable of the economic advantage -and not just to determine the household head- we found impossible to obtain that variable homogeneously among countries -some countries provide only gross income while others provide only the net measure- and therefore discarded that option. Also please note than in our tables and figures we refer to the years when the income reported was obtained: 2004 and 2010.
} 
life-income cycle, and to include cohorts with the highest proportion of employed individuals [Ferreira and Gignoux (2011)], only household heads within the 30-50 years of age range are kept. We have also removed extreme outlier observations of equivalent income; specifically, those placed more than three quartiles below or above the adjusted interquartile range. ${ }^{18}$ Descriptive statitistics for income and all parental and individual variables in each country and wave are presented in Appendix Tables A1 and A2.

In general, our descriptive statistics find differences in average equivalent income similar in rank to the ones found in national accounts statistics (i.e. using GDP per capita), with Luxembourg and Norway on top of the list. Nordic and central countries, in general, show higher shares of parents with higher level of education, a pattern that also occurs when we consider the educational level of the individual. Note also that, in all countries, the share of individuals with higher education is greater than the share of parents (either fathers or mothers) with higher education; the opposite occurs when we look at the shares of the individuals with the lowest educational levels. Also, nordic and central countries tend to show higher shares of parents and individuals with professional, managerial or technical occupational categories.

The results from regressing income on circumstances for each country and wave in order to obtain the $y_{i}{ }^{C}$ smoothed distribution (Eq. (5)) are shown in Appendix Tables A3.A to A3.E. In general, higher levels of parental education, both for father and mother, have positive coefficents (the omited category is 'low education'), and are significant in most of the countries. Occupational categories of the father such as "Professional" or "Managerial" generally have positive coefficients and are significant in most of the cases; other categories are not always significant and have ambiguous coefficients (the omitted category is 'skilled agricultural'). Regarding the financial situation of the household during childhood, the category "Difficulties most of the time" has the expected negative coefficient (the omitted category is "Difficulties rarely") and is significant in most of the countries. The female-gender dummy has a negative coefficient and is also significant in most cases. Finally, being a citizen from a non-EU country

\footnotetext{
${ }^{18}$ We have calculated the adjusted boxplot for each country and wave, accounting for skewedness, and using the parameter 3 to exclude extreme outliers see [Hubert and Vandervieren (2008)].
} 
has a negative and significant coefficient for most of the contries analysed (here the ommited category is being a national citizen).

Tables A4.A to A4.E in the Appendix show the estimated coefficients in the 'second step' regressions for each educational level and each occupational category (Eq. [13) and Eq. (16)] for all countries and waves. ${ }^{19}$ The coefficient for 'tertiary education' tends to be positive and significant in both waves in most countries, while the opposite happens with the coefficients for 'primary' and 'pre-primary' levels of education. Among the professional categories, the ‘elementary occupation' category shows in general a negative and significant coefficient, while both 'professional' and 'managerial' categories tend to have positive and significant coefficients in most countries.

\section{Inequality and Inequality of opportunity in Europe in 2004 and 2010}

The period analysed, 2004 and 2010, includes the end of a high economic growth era and the first impact of a deep economic slowdown. For the 28 European Union countries as a whole, real GDP growth rates changed from around $3 \%$ in the years before 2008, to an average growth rate in the 2008-2013 period of around 0\% per year. ${ }^{20}$ Although the effects of the 'Great Recession' on the variables we analyse were probably longer in time and higher in magnitude, changes between the 2004 and the 2010 waves could partially represent the impact of the first part of the recession.

In this section, we first have a look at the results for total income inequality between the two waves and compare them with the IO performance, while the association of IO with individual education and occupation will be analysed in Section 5. The inequality indices and standard

\footnotetext{
${ }^{19}$ Unlike parental education, the respondent's education is categorised in ISCED levels for both waves. The occupation, on the other hand, is coded using the same one-digit groups from the ISCO-88. Note the omitted categories in these regressions are 'Upper Secondary (ISCED 3)' for education, and 'Skilled Agricultural' for occupation

${ }^{20}$ See http://ec.europa.eu/eurostat/web/products-datasets/-/tec00115.
} 
errors for the equivalent household income of individuals in our sample are calculated for the 26 countries analysed in the 2004 and 2010 wave, and presented in the first four columns of Table 1. The IO estimates and standard errors are shown in the last four columns of Table 1. Figures 1 and 2 show the inequality and IO values, respectively, for 2004 in the X-axis and for 2010 in the Y-axis. ${ }^{21}$

As shown in Figure 1, total inequality did not suffer radical changes in most countries. It increased slightly in Iceland, Germany, Italy and Spain, while it decreased in Austria, Lithuania and, especially, in Portugal and Poland. Nordic countries are consistently at the bottom of the inequality ranking in both waves, with the exception of Iceland in 2010, that shows a higher level of inequality than its Nordic neighbours, probably influenced by the stronger impact of the recession in that country that, as we will see, could also affect its IO levels. The Baltic republics, Poland and the Mediterranean countries show the highest degree of inequality in both waves, while the western-central Europe countries (Netherlands, Belgium, France, Austria, Germany and Luxembourg) and some of the former communist countries (Slovenia, Slovakia, Hungary or the Czech Republic) have inequality levels just above those of the Nordic countries. Ireland and the United Kingdom are placed -in terms of inequalitybetween the Mediterranean and the central European countries, while Cyprus is an exception, with lower levels of inequality than its Mediterranean counterparts. ${ }^{22}$

In terms of IO, our homogeneous set of circumstances for all countries in both waves allows for a cross-country comparison of the results (Figure 2). Going from the bottom to the top in the most recent wave, we see Nordic countries are placed at the lower end of the IO ranking, as they were in the inequality measure. Iceland is, again, a 'Nordic outlier' in 2010. Among the Central European countries (we include here Ireland and the UK for simplicity), Germany and

\footnotetext{
${ }^{21}$ Standard errors for the inequality indexes have been calculated by bootstrapping with 1000 replicates.

${ }^{22}$ Our ranking for the 2004 wave -both for total inequality and for inequality of opportunity- is consistent with Marrero and Rodríguez (2012), with minor differences in the values of particular countries due to different database decisions. Our 2010 results are also in line with Brzezinski (2015), who reproduces the work of Marrero and Rodríguez (2012) for both waves. Again, some minor discrepancies with our estimations can be attributed to different data choices. Also note that -compared to these previous works on IO in Europe- we add Cyprus, Iceland and Luxembourg to the sample of countries.
} 
Netherlands have lower IO levels (comparable to those of the Nordic countries) while France, Austria and the UK have higher IO ranking positions, just above Slovenia, Slovakia and the Czech Republic in 2010. Next, we find a mixed group that includes Belgium, Ireland, Italy and most of the other East European countries (Estonia, Hungary, Poland, Latvia and Lithuania), while Spain and Cyprus are at the higher end of this group; finally, Luxembourg, Greece and Portugal occupy the top of the IO ranking in 2010. The comparison between inequality and IO rankings shows that the Baltic republics rank better in terms of IO than in terms of sheer inequality, while the opposite occurs for Belgium and, specially, for Luxembourg.

As for the dynamics of IO over this period, only Portugal, Poland, Latvia and Lithuania show a significant decrease in IO, with Italy and Sweden presenting also minor decreases. Portugal is still among the countries with the highest levels of IO, but its situation has relatively improved compared to 2004, when its IO was far above all other European countries analized. Most of all other countries are along the $45^{\circ}$ line (Norway, Finland, Czech Republic and the UK) or slightly above it, showing a small increase (Denmark, Germany, Slovenia, France, Austria, Ireland, Spain and Cyprus). Finally, Hungary and Estonia show a moderate increment, and it is Slovakia, Iceland, Belgium and Greece who show the highest increase in inequality of opportunity between 2004 and 2010 .

\section{The mediating role of education and occupation}

Although the results presented in Section 4 are certainly relevant, we believe, as discussed in the introduction, that an analysis of the possible channels of these levels of inequality of opportunity could be of great interest. Thus, we turn now to results obtained by applying our proposed method -presented in Section 2- to our sample of 26 European countries in 2004 and 2010 .

Table 2 shows the percentage of IO associated with individual education and occupation, while Table 3 presents the absolute values of $I O_{E D U}$ and $I O_{O C C}$ for each country and wave. First of all, results still reveal a relevant role of the level of education as a channel of IO. 
Relative to the total estimate of IO in each country and wave, we find (see Figure 5) that the level of education attained by the individual can mediate about one third of IO in Portugal and Luxembourg, almost one quarter in Greece and Hungary, and more than $20 \%$ in Italy and Poland. Most of the other countries are in the $8 \%-20 \%$ range, with the Nordic countries -except Norway- showing the lowest share of IO channelled through education ${ }^{23}$

The change in the channelling importance of the educational level between the two waves shows an important increase in Greece, with Germany, Norway, Luxembourg, Slovakia, Belgium and Austria also having moderate increments. There is a marked decrease in Sweden, Finland and Iceland, while Spain, Ireland, Slovenia and Cyprus present a moderate decrease. The rest of the countries remain close to the $45^{\circ}$ line and show no significant changes between the two waves.

The other potential candidate to channel IO present in the EU-SILC database is the occupational category of the individual, since it is related both to income and circumstances. However, once we control for education, the share of IO channelled by the occupational category is relatively small in most countries, amounting only to between $1 \%$ and $5 \%$ in most countries and to around $8 \%$ in Cyprus and Austria in the most recent wave (Figure 8). These two countries are also the only ones in which this share shows a clear increase between the two waves. On the other hand, Norway, Germany, Finland, Hungary and Ireland show a decrease in the share of IO, with Greece, Latvia and the Czech Republic showing a smaller decrease. The rest of countries channel similar shares of IO through occupation in both waves. In general, we observe a greater degree of dispersion in the change overtime of the share of IO channelled through occupation than in the share channelled by education. However, no clear trend or geographical pattern is observed in either case. ${ }^{24}$

Combined, the occupational category and the educational level explain up to $35 \%$ of IO

\footnotetext{
${ }^{23}$ The level of education also seems to account for a similar share of the intergenerational income elasticity (IGE). Eide and Showalter (1999) and Palomino et al. (2014) find that controlling for education the value of IGE decreases by around 30\% using OLS, while Blanden et al. (2014) finds a decrease close to $50 \%$

${ }^{24}$ When we plot the absolute levels of IO instead of the relative shares, the rankings of countries and evolution overtime of the education and occupation channels do not change significantly (see Figures 9 and 10).
} 
(Portugal and Luxembourg; less in the rest of the countries). Although it represents an important share of IO -and it could explain part of the unfortunate lead that Portugal, Greece and Luxembourg had in inequality of opportunity in 2010- we must not forget there is still an important part of IO not associated with either of these factors. According to our estimates, more than $70 \%$ of IO is mediated by unoserved factors other the educational level and the educational category. As pointed out by other studies, school quality or parental connections could be some of the most relevant mediators channeling that share of IO unexplained by our limited set of mediators. Chetty et al. (2014) find for the U.S., in that line, that rank intergenerational mobility is related to the quality of the schools in different geographical areas. But there could be many more and less obvious channels. Neumann et al. (2009), for example, point at another source of earnings and that, in our context, could be a potential IO mediator: job congruence, (i.e., the similarity between job interests and the actual job). It could be the case that some circumstances should favour a more free or informed career choice and, therefore, a higher income. As richer databases become available, we believe our strategy should be applied to the exploration of more potentially important mediators.

\section{The educational IO channel and the expansion of higher education}

We focus next on analysing the different share of IO channelled by education in different European countries and the possible relation with different national variables, carrying out a simple but illustrative exercise. The intuition of the channelling role of education on income opportunities is simple: people with more favourable circumstances achieve higher educational levels, which, in turn, enable them to obtain more income through increased productivity. In line with this theoretical relation, our results provide an objective measure of how much of the circumstance-conditioned income is obtained through different levels of education. We find that, even though we cannot account for the possible variation in quality within the same level of schooling, the share is still relevant, implying that acting on the educational channel of 
transmission could potentially reduce the measure of IO in up to one third in some countries. Thus, the relevance of the educational level achieved by the individual as a channel of IO raises another question: which factors are associated with the role of education in the transmission of opportunities? Clear candidates can be found in the own average levels of education attained at each country. Having a relatively big sample of 26 countries at two different points in time, we have performed a descriptive cross-correlation analysis, comparing the access to different levels of education of the population and the channelling role of education (Table 4). Figure 11 shows that EU countries with a bigger share of population with higher (tertiary) education seem to have a smaller share of IO channelled through education. On the contrary, that correlation turns positive with the percentage of the population attaining only the lowest levels of education (Figure 12). ${ }^{25}$ As could be expected, given that the occupational channel is measured net of the educational level, the share of IO channelled through the occupational category and the share of the population with high level (or low level) of studies show no clear correlation (Figures 13, 14 and A3 and A4 in the Appendix).

Indirectly, the role of education in channelling IO might shed some light on the debate about the effect of educational investment on economic growth. This effect has traditionally been attributed to direct increases in skills (and productivity) and to positive social externalities of education [Angrist and Krueger (1991), Card (1999) or Krueger and Lindahl (2001)]. Since IO has recently been found to be negative for growth [Marrero and Rodríguez (2013) and (2016), Marrero et al. (2016) and Bradbury and Triest (2016)], our results add a third possible connection between education and growth, the one that takes place via a decrease in IO. However, we leave the exploration of this avenue for future research.

\footnotetext{
${ }^{25}$ This correlation also occurs when we take into account the absolute level of the educational channel of IO instead of the share it represents over total inequality of opportunity (Appendix Figures A1 and A2).
} 


\section{Concluding Remarks}

In this paper we try to go beyond the beaten path of IO measurement and cross-country comparisons and disentangle the channels through which different circumstances turn into different incomes. Using data from the EU-SILC survey, we present a simple new strategy to decompose ex-ante measures of inequality of opportunity in their educational and occupational channels. Nonetheless, this method could be extended to the ex-post approach and to different transmission channels (e.g. education quality or work connections) if appropriate data were available.

In short, our proposed methodology obtains the circumstance-determined income (the smoothed distribution) and successively decomposes it -using log-linear regression- by orthogonal mediating factors, following the natural order in which these mediators come into play (first education and then occupation). Finally, using the decomposable MLD index, the inequality of the smoothed distribution is partitioned into the different shares of inequality of opportunity explained by each considered factor.

Applying this methodology to data from 26 European countries in 2004 and 2010, we find that a relevant share of IO is channelled through the different levels of education. In 2010, this share accounts to around one third of IO in Portugal and Luxembourg, almost one quarter in Greece and Hungary, and more than one fifth in Italy and Poland. Most of the other countries are in the $8 \%-20 \%$ range. Once the educational channel is taken into account, the importance of the occupational channel is relatively small, channelling less than $5 \%$ of IO in most countries. On the other hand, although particular countries have suffered significant changes, we find no general pattern of change in the shares of IO channelled by education and occupation in the two waves of data analysed.

We believe that our findings, although limited to only the level of education and the occupational category, may be relevant for practitioners and policymakers concerned about inequality of opportunity. We provide some evidence of what before was only an intuition: that a significant share of inequality of opportunity derives from the different level of education that people 
with different circumstances can achieve. In addition, we find the occupational category to have limited importance once the education channel has been taken into account.

Also, trying to explore the factors that explain the differential importance of the educational channel across countries, we have detected a positive (negative) correlation between the share of IO channelled by education and the share of the population with low education (tertiary education). It seems that when more people can achieve levels of education above lower education and tertiary education is more broadly accessible to the population, the IO channelled through this variable decreases (both in absolute and relative terms).

Finally, and notwithstanding the importance of the educational level, the relevant share of IO still unexplained by our set of variables remains a challenge for future research. In that line, we believe our method provides a simple useful strategy for the prospective analysis of other potential channels (e.g., education quality, social connections) when the necessary data are available. 


\section{References}

Angrist, J. D. and Krueger, A. B. (1991). Does compulsory school attendance affect schooling and earnings? Quarterly Journal of Economics, 106(4):979-1014.

Atkinson, A. B. (1970). On the measurement of inequality. Journal of economic theory, $2(3): 244-263$.

Becker, G. S. (1964). Human capital: A theoretical and empirical analysis, with special reference to education. University of Chicago Press, 2009 edition.

Blanden, J., Haveman, R., Smeeding, T., and Wilson, K. (2014). Intergenerational mobility in the United States and Great Britain: a comparative study of parent-child pathways. Review of Income and Wealth, 60(3):425-449.

Bourguignon, F. (1979). Decomposable income inequality measures. Econometrica: Journal of the Econometric Society, pages 901-920.

Bourguignon, F., Ferreira, F. H., and Menendez, M. (2007). Inequality of opportunity in Brazil. Review of income and Wealth, 53(4):585-618.

Bradbury, K. and Triest, R. K. (2016). Inequality of opportunity and aggregate economic performance. RSF: The Russell Sage Foundation Journal of the Social Sciences, 2(2):178201.

Brzezinski, M. (2015). Inequality of opportunity in Europe before and after the Great Recession. University of Warsaw - Working Papers, No.2/2015 (150).

Card, D. (1999). The causal effect of education on earnings. Handbook of labor economics, $3: 1801-1863$.

Checchi, D. and Peragine, V. (2010). Inequality of opportunity in Italy. The Journal of Economic Inequality, 8(4):429-450.

Checchi, D., Peragine, V., and Serlenga, L. (2016). Inequality of Opportunity in Europe: Is 
There a Role for Institutions? Inequality: Causes and Consequences (Research in Labor Economics, Volume 43), pages 1-44.

Chetty, R., Hendren, N., Kline, P., and Saez, E. (2014). Where is the land of opportunity? The geography of intergenerational mobility in the United States. Technical report, National Bureau of Economic Research.

Eide, E. R. and Showalter, M. H. (1999). Factors affecting the transmission of earnings across generations: A quantile regression approach. Journal of Human Resources, pages 253-267.

Ferreira, F. H. and Gignoux, J. (2011). The measurement of inequality of opportunity: Theory and an application to Latin America. Review of Income and Wealth, 57(4):622-657.

Ferreira, F. H. and Gignoux, J. (2014). The measurement of educational inequality: Achievement and opportunity. The World Bank Economic Review, 28(2):210-246.

Fleurbaey, M. (2008). Fairness, responsibility, and welfare. Oxford University Press.

Fleurbaey, M. and Peragine, V. (2013). Ex ante versus ex post equality of opportunity. Economica, 80(317):118-130.

Foster, J. E. and Shneyerov, A. A. (2000). Path independent inequality measures. Journal of Economic Theory, 91(2):199-222.

Gamboa, L. F. and Waltenberg, F. D. (2012). Inequality of opportunity for educational achievement in Latin America: Evidence from PISA 2006-2009. Economics of Education Review, 31(5):694-708.

Hubert, M. and Vandervieren, E. (2008). An adjusted boxplot for skewed distributions. Computational statistics Éamp; data analysis, 52(12):5186-5201.

Ingram, B. F. and Neumann, G. R. (2006). The returns to skill. Labour economics, 13(1):3559.

Krueger, A. B. and Lindahl, M. (2001). Education for growth: Why and for whom? Journal of Economic Literature, 39(4):1101-1136. 
Lefranc, A., Pistolesi, N., and Trannoy, A. (2008). Inequality of opportunities vs. inequality of outcomes: Are western societies all alike? Review of Income and Wealth, 54(4):513-546.

Lemieux, T. (2006). The "Mincer equation" thirty years after schooling, experience, and earnings. Springer.

Li Donni, P., Rodríguez, J. G., and Rosa Dias, P. (2015). Empirical definition of social types in the analysis of inequality of opportunity: a latent classes approach. Social Choice and Welfare, 44(3):673-701.

Lucas, R. E. (1988). On the mechanics of economic development. Journal of monetary economics, 22(1):3-42.

Marrero, G. A. and Rodríguez, J. G. (2012). Inequality of opportunity in Europe. Review of Income and Wealth, 58(4):597-621.

Marrero, G. A. and Rodríguez, J. G. (2013). Inequality of opportunity and growth. Journal of Development Economics, 104:107-122.

Marrero, G. A. and Rodríguez, J. G. (2016). Inequality ... of opportunity and economic performance. Federal Reserve Bank of St. Louis Review, ((Forthcoming)).

Marrero, G. A., Rodríguez, J. G., and Van der Weide, R. (2016). Unequal opportunity, unequal growth. Mimeo.

Neumann, G., Olitsky, N., and Robbins, S. (2009). Job congruence, academic achievement, and earnings. Labour Economics, 16(5):503-509.

Palomino, J. C., Marrero, G. A., and Rodríguez, J. G. (2014). One size doesn't fit all: A quantile analysis of intergenerational income mobility in the US (1980-2010). ECINEQ Working Papers.

Pérez-González, F. (2006). Inherited control and firm performance. The American Economic Review, 96(5):1559-1588. 
Psacharopoulos, G. (1994). Returns to investment in education: A global update. World development, 22(9):1325-1343.

Ramos, X. and Van de Gaer, D. (2012). Empirical approaches to inequality of opportunity: Principles, measures, and evidence.

Rawls, J. (1971). A Theory of Justice. Harvard University Press, Cambridge, Ma.

Rodríguez, J. G. (2008). Partial equality-of-opportunity orderings. Social Choice and Welfare, $31(3): 435-456$.

Roemer, J. E. (1993). A pragmatic approach to responsibility for the egalitarian planner. Philosophy Public Affairs, (20):146-166.

Roemer, J. E. (2009). Equality of opportunity. Harvard University Press.

Roemer, J. E., Aaberge, R., Colombino, U., Fritzell, J., Jenkins, S. P., Lefranc, A., Marx, I., Page, M., Pommer, E., Ruiz-Castillo, J., et al. (2003). To what extent do fiscal regimes equalize opportunities for income acquisition among citizens? Journal of Public Economics, $87(3): 539-565$.

Sen, A. (1980). Equality of what?, volume 1. Tanner Lectures on Human Values.

Shorrocks, A. F. (1980). The class of additively decomposable inequality measures. Econometrica: Journal of the Econometric Society, pages 613-625.

Sullivan, P. (2010). Empirical evidence on occupation and industry specific human capital. Labour economics, 17(3):567-580.

Trostel, P., Walker, I., and Woolley, P. (2002). Estimates of the economic return to schooling for 28 countries. Labour economics, 9(1):1-16. 


\section{Tables and Figures}

Table 1: Inequality and Inequality of Opportunity Europe - 2004 and 2010.

\begin{tabular}{|c|c|c|c|c|c|c|c|c|}
\hline & \multicolumn{4}{|c|}{ Inequality } & \multicolumn{4}{|c|}{ Inequality of Opportunity } \\
\hline & \multicolumn{2}{|c|}{2004} & \multicolumn{2}{|c|}{2010} & \multicolumn{2}{|c|}{2004} & \multicolumn{2}{|c|}{2010} \\
\hline Country & Index & SD & Index & SD & Index & SD & Index & SD \\
\hline AT & 0.1192 & 0.008 & 0.1024 & 0.004 & 0.0096 & 0.0004 & 0.0136 & 0.0005 \\
\hline $\mathrm{BE}$ & 0.0913 & 0.004 & 0.1000 & 0.005 & 0.0088 & 0.0004 & 0.0197 & 0.0010 \\
\hline $\mathrm{CY}$ & 0.1129 & 0.004 & 0.1284 & 0.006 & 0.0227 & 0.0009 & 0.0268 & 0.0013 \\
\hline $\mathrm{CZ}$ & 0.1125 & 0.006 & 0.1076 & 0.004 & 0.0114 & 0.0005 & 0.0108 & 0.0004 \\
\hline $\mathrm{DE}$ & 0.1033 & 0.003 & 0.1308 & 0.004 & 0.0026 & 0.0001 & 0.0060 & 0.0001 \\
\hline DK & 0.0584 & 0.004 & 0.0738 & 0.004 & 0.0021 & 0.0002 & 0.0064 & 0.0003 \\
\hline $\mathrm{EE}$ & 0.1893 & 0.009 & 0.1891 & 0.010 & 0.0174 & 0.0006 & 0.0236 & 0.0011 \\
\hline EL & 0.1771 & 0.007 & 0.1734 & 0.010 & 0.0221 & 0.0009 & 0.0335 & 0.0014 \\
\hline $\mathrm{ES}$ & 0.1897 & 0.005 & 0.2136 & 0.007 & 0.0229 & 0.0005 & 0.0267 & 0.0009 \\
\hline FI & 0.0845 & 0.003 & 0.0896 & 0.005 & 0.0044 & 0.0003 & 0.0033 & 0.0002 \\
\hline FR & 0.1051 & 0.003 & 0.1101 & 0.003 & 0.0098 & 0.0003 & 0.0121 & 0.0004 \\
\hline $\mathrm{HU}$ & 0.1191 & 0.004 & 0.1228 & 0.003 & 0.0156 & 0.0006 & 0.0215 & 0.0005 \\
\hline $\mathrm{IE}$ & 0.1382 & 0.006 & 0.1463 & 0.007 & 0.0189 & 0.0008 & 0.0224 & 0.0009 \\
\hline IS & 0.0882 & 0.009 & 0.1156 & 0.021 & 0.0060 & 0.0005 & 0.0138 & 0.0028 \\
\hline $\mathrm{IT}$ & 0.1526 & 0.004 & 0.1692 & 0.005 & 0.0245 & 0.0006 & 0.0208 & 0.0005 \\
\hline LT & 0.2326 & 0.010 & 0.2168 & 0.017 & 0.0332 & 0.0015 & 0.0211 & 0.0022 \\
\hline $\mathrm{LU}$ & 0.1198 & 0.008 & 0.1235 & 0.006 & 0.0282 & 0.0016 & 0.0334 & 0.0012 \\
\hline LV & 0.2269 & 0.011 & 0.2386 & 0.009 & 0.0297 & 0.0011 & 0.0209 & 0.0006 \\
\hline NL & 0.0937 & 0.005 & 0.0950 & 0.004 & 0.0041 & 0.0002 & 0.0047 & 0.0003 \\
\hline $\mathrm{NO}$ & 0.0602 & 0.003 & 0.0694 & 0.004 & 0.0033 & 0.0002 & 0.0037 & 0.0002 \\
\hline PL & 0.2462 & 0.005 & 0.1637 & 0.004 & 0.0285 & 0.0005 & 0.0197 & 0.0004 \\
\hline $\mathrm{PT}$ & 0.2110 & 0.009 & 0.1744 & 0.007 & 0.0451 & 0.0024 & 0.0347 & 0.0014 \\
\hline $\mathrm{SE}$ & 0.0660 & 0.003 & 0.0735 & 0.006 & 0.0045 & 0.0003 & 0.0016 & 0.0001 \\
\hline SI & 0.0869 & 0.004 & 0.0972 & 0.005 & 0.0077 & 0.0002 & 0.0101 & 0.0004 \\
\hline SK & 0.1053 & 0.003 & 0.1154 & 0.006 & 0.0034 & 0.0001 & 0.0118 & 0.0004 \\
\hline UK & 0.1613 & 0.008 & 0.1603 & 0.006 & 0.0170 & 0.0005 & 0.0145 & 0.0005 \\
\hline
\end{tabular}




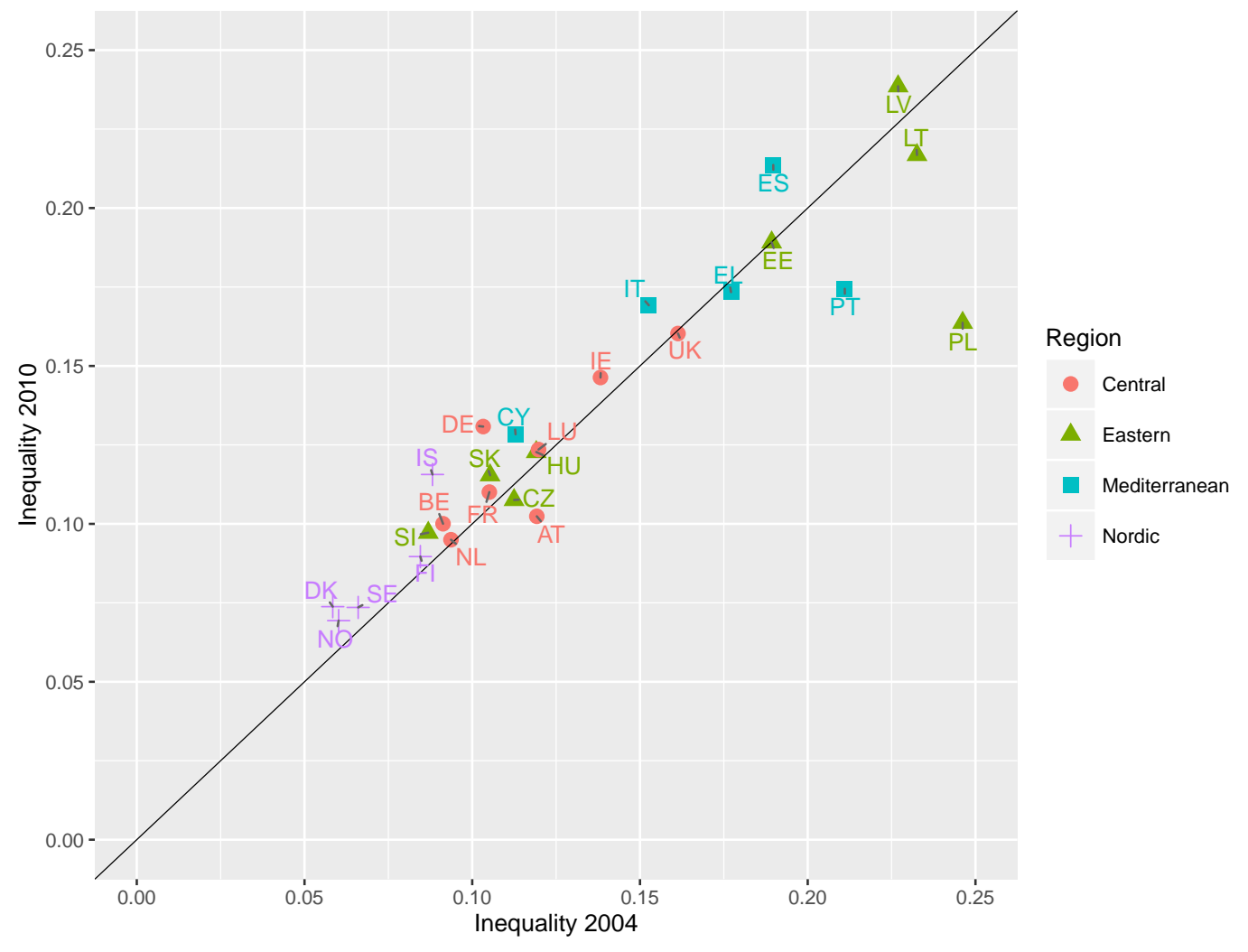

Figure 1: Inequality in Europe - 2004 and 2010. 


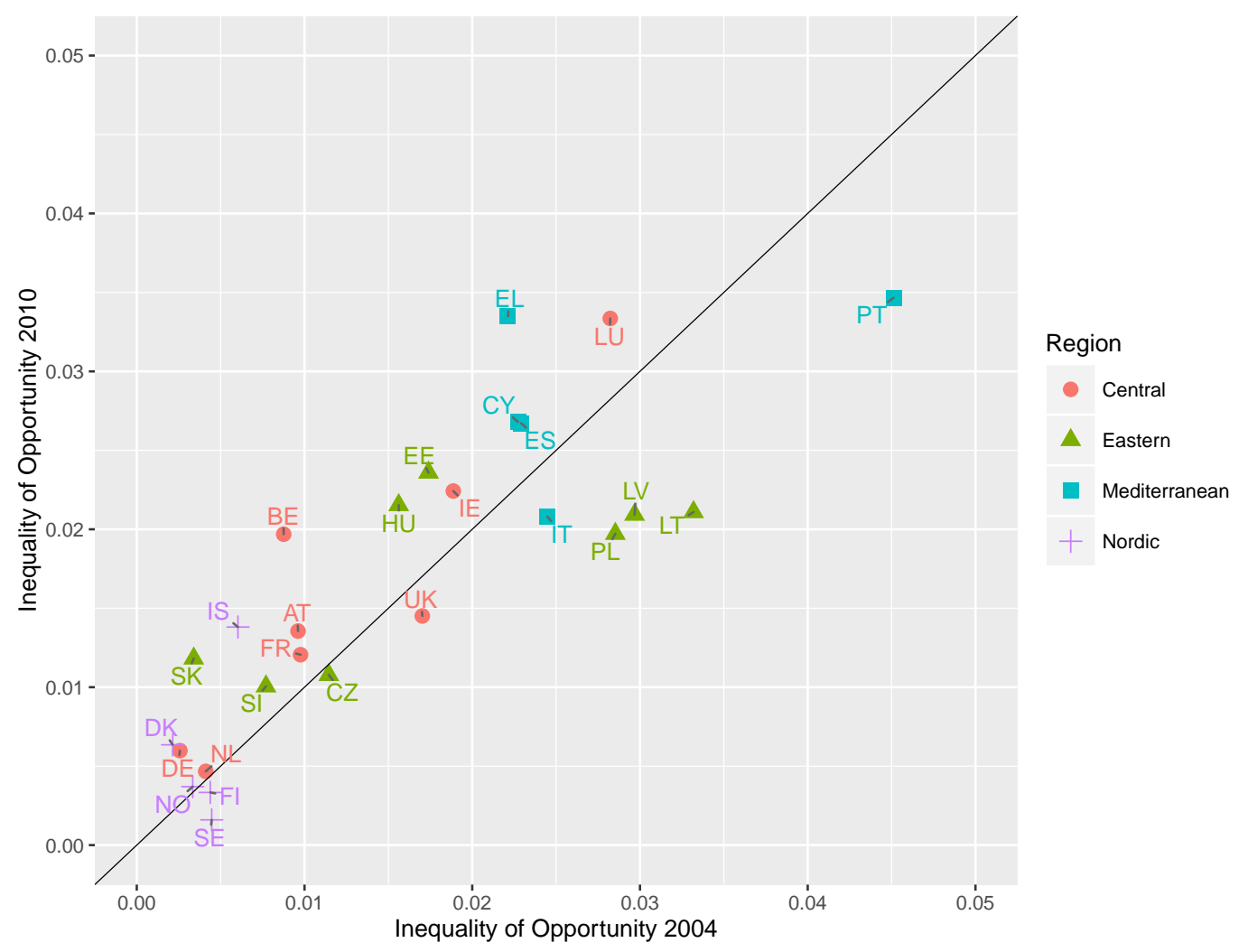

Figure 2: Inequality of Opportunity in Europe - 2004 and 2010. 


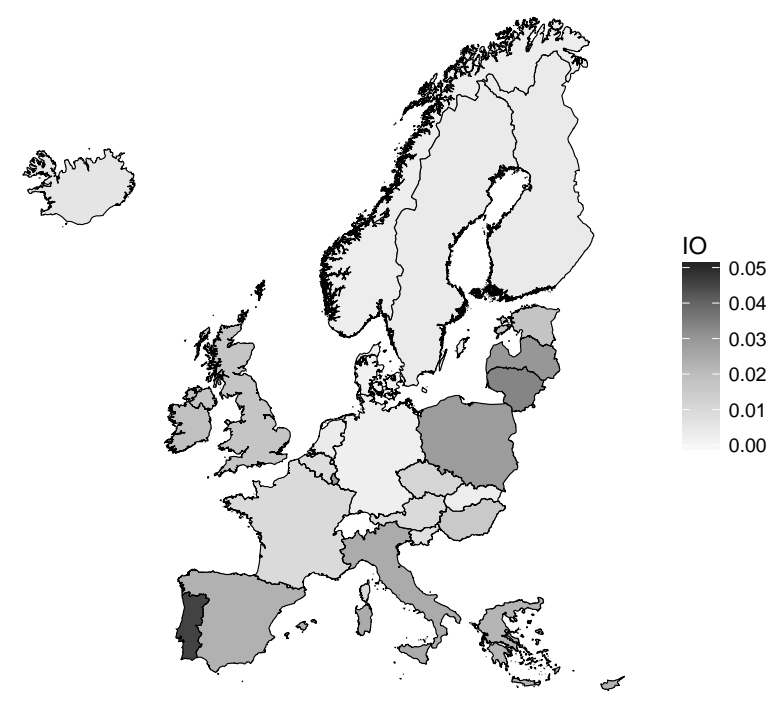

Figure 3: Inequality of opportunity 2004

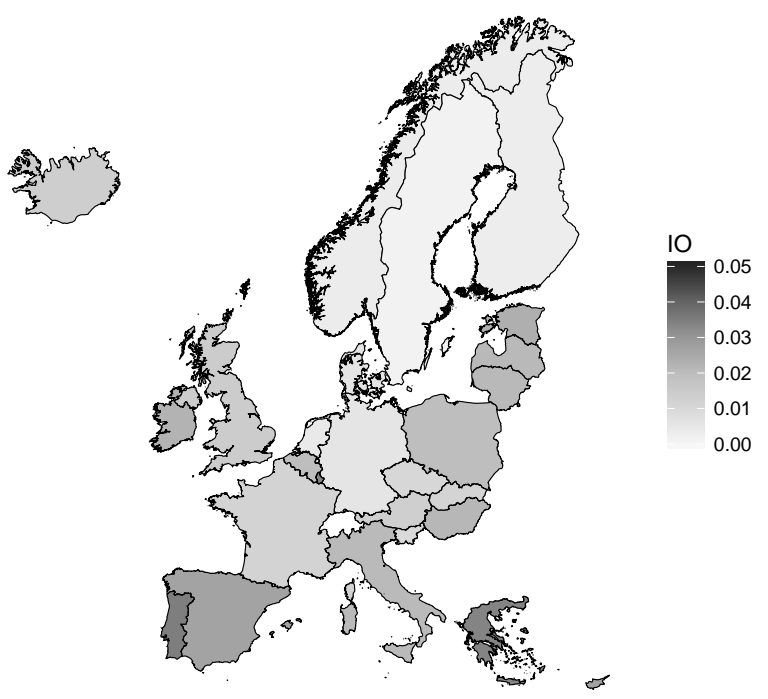

Figure 4: Inequality of opportunity 2010 
Table 2: Share of Inequality of Opportunity channelled through Education and Occupation - 2004 and 2010.

\begin{tabular}{ccccc} 
& Education Share $(\%)$ & Occupation & Share $(\%)$ \\
\hline Country & 2004 & 2010 & 2004 & 2010 \\
\hline AT & 13.06 & 16.77 & 5.79 & 7.69 \\
BE & 10.99 & 15.19 & 3.19 & 3.65 \\
CY & 19.96 & 14.40 & 5.52 & 8.24 \\
CZ & 15.14 & 18.04 & 3.28 & 2.37 \\
DE & 1.99 & 8.41 & 5.40 & 3.00 \\
DK & 5.39 & 6.36 & 2.94 & 3.27 \\
EE & 5.94 & 7.89 & 4.65 & 3.85 \\
EL & 14.24 & 24.02 & 4.87 & 3.68 \\
ES & 19.91 & 16.15 & 3.51 & 4.34 \\
FI & 6.95 & 0.12 & 5.30 & 3.51 \\
FR & 14.75 & 14.05 & 2.33 & 2.93 \\
HU & 23.81 & 23.98 & 2.99 & 1.21 \\
IE & 19.15 & 14.99 & 4.01 & 2.16 \\
IS & 7.93 & 0.07 & 2.06 & 2.70 \\
IT & 20.41 & 20.35 & 3.26 & 3.16 \\
LT & 11.75 & 10.14 & 2.90 & 2.61 \\
LU & 26.20 & 31.01 & 4.37 & 3.81 \\
LV & 10.76 & 8.86 & 2.90 & 1.48 \\
NL & 9.56 & 12.06 & 0.93 & 1.78 \\
NO & 4.93 & 11.39 & 6.04 & 1.48 \\
PL & 21.48 & 21.90 & 4.97 & 5.39 \\
PT & 32.85 & 32.50 & 0.98 & 1.46 \\
SE & 7.20 & 1.26 & 1.71 & 1.92 \\
SI & 19.19 & 14.67 & 3.83 & 4.33 \\
SK & 8.09 & 12.19 & 2.10 & 1.60 \\
UK & 9.44 & 10.12 & 4.09 & 4.94 \\
\hline
\end{tabular}




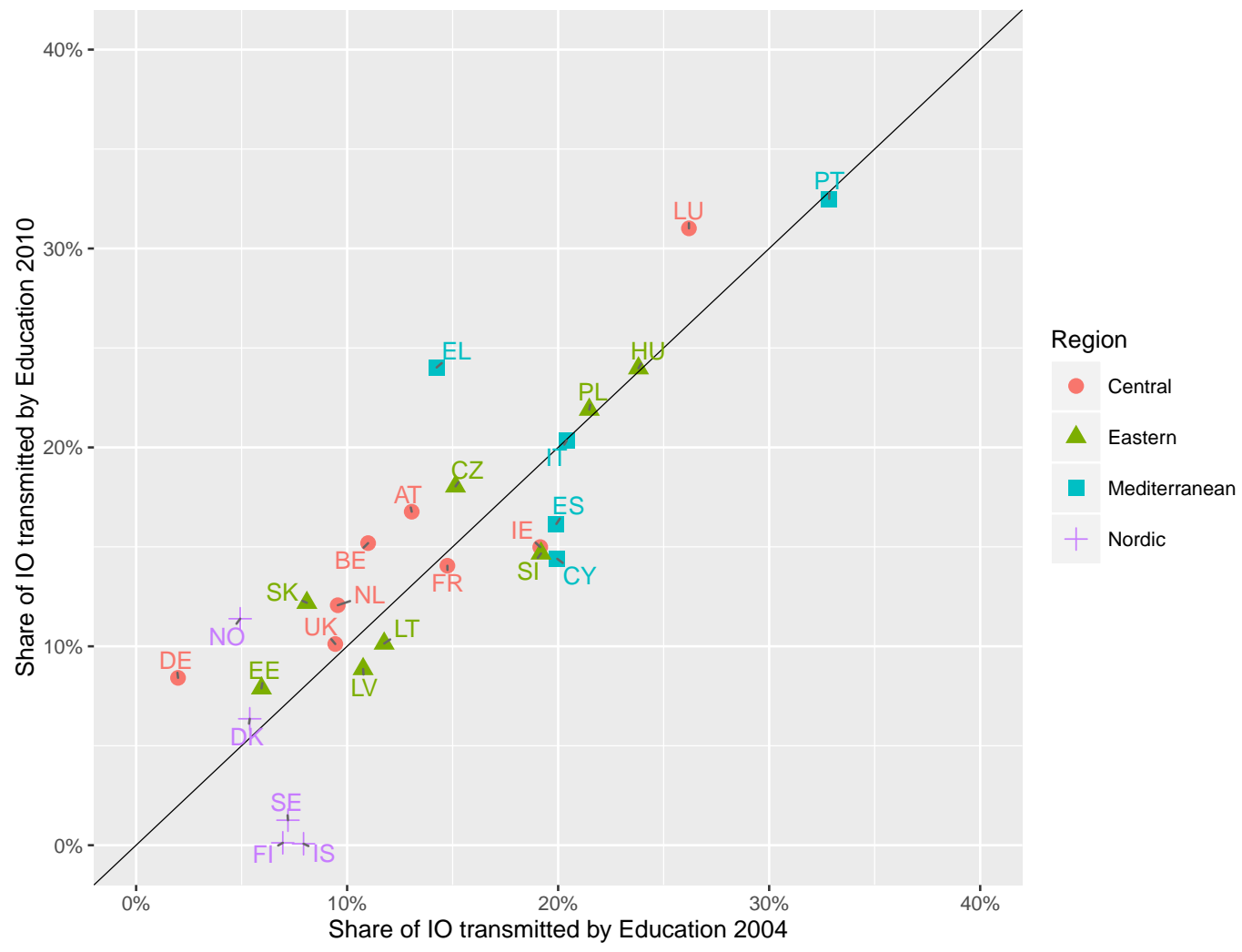

Figure 5: Share of Inequality of Opportunity channelled through Education in Europe - 2004 and 2010. 


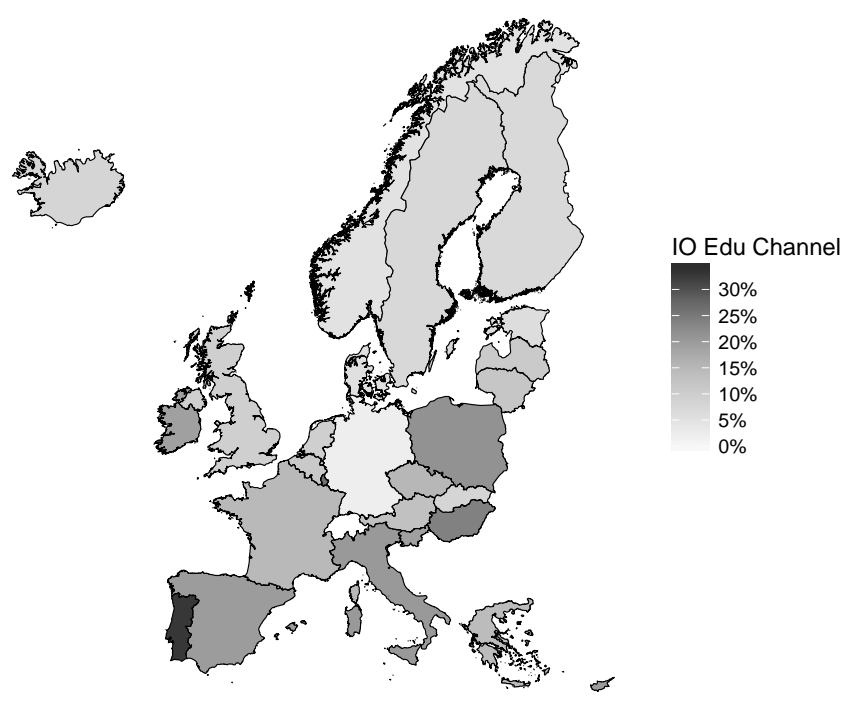

Figure 6: Education IO Channel 2004



Figure 7: Education IO Channel 2010 


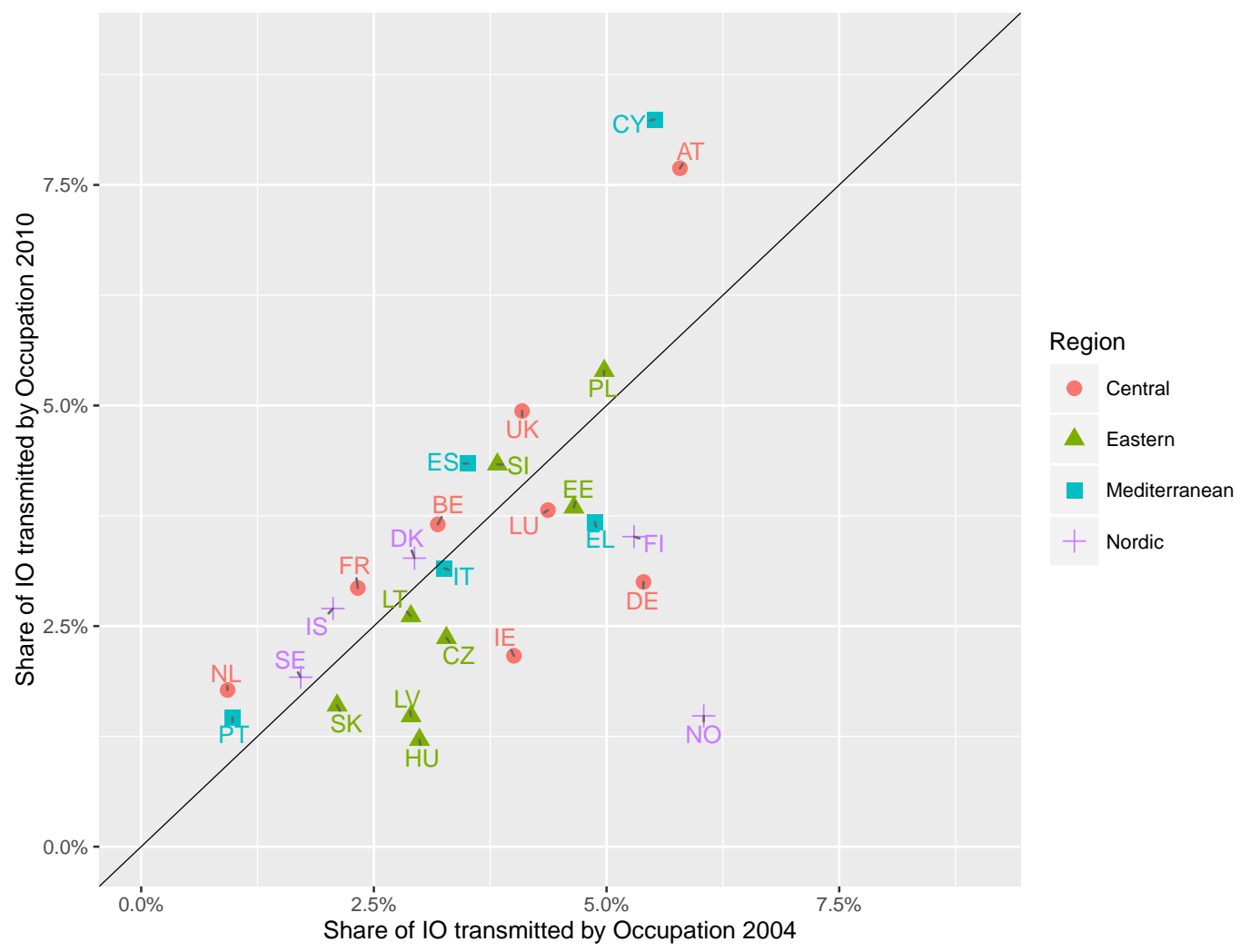

Figure 8: Share of Inequality of Opportunity channelled through Occupation in Europe - 2004 and 2010. 
Table 3: Inequality of Opportunity channelled through Education and Occupation - 2004 and 2010.

IO Educational Channel

\begin{tabular}{|c|c|c|c|c|c|c|c|c|}
\hline & \multicolumn{2}{|c|}{2004} & \multicolumn{2}{|c|}{2010} & \multicolumn{2}{|c|}{2004} & \multicolumn{2}{|c|}{2010} \\
\hline Country & Index & SD & Index & SD & Index & SD & Index & $\mathrm{SD}$ \\
\hline$\overline{\mathrm{AT}}$ & 0.0013 & 0.0003 & 0.0023 & 0.0005 & 0.0006 & 0.0002 & 0.0010 & 0.0002 \\
\hline $\mathrm{BE}$ & 0.0010 & 0.0003 & 0.0030 & 0.0007 & 0.0003 & 0.0001 & 0.0007 & 0.0003 \\
\hline $\mathrm{CY}$ & 0.0045 & 0.0007 & 0.0039 & 0.0010 & 0.0013 & 0.0003 & 0.0022 & 0.0006 \\
\hline $\mathrm{CZ}$ & 0.0017 & 0.0005 & 0.0019 & 0.0004 & 0.0004 & 0.0002 & 0.0003 & 0.0001 \\
\hline $\mathrm{DE}$ & 0.0001 & 0.0000 & 0.0005 & 0.0001 & 0.0001 & 0.0001 & 0.0002 & 0.0001 \\
\hline DK & 0.0001 & 0.0001 & 0.0004 & 0.0003 & 0.0001 & 0.0001 & 0.0002 & 0.0002 \\
\hline $\mathrm{EE}$ & 0.0010 & 0.0004 & 0.0019 & 0.0009 & 0.0008 & 0.0004 & 0.0009 & 0.0005 \\
\hline EL & 0.0032 & 0.0008 & 0.0080 & 0.0015 & 0.0011 & 0.0003 & 0.0012 & 0.0004 \\
\hline $\mathrm{ES}$ & 0.0046 & 0.0007 & 0.0043 & 0.0007 & 0.0008 & 0.0002 & 0.0012 & 0.0003 \\
\hline FI & 0.0003 & 0.0001 & 0.0000 & 0.0001 & 0.0002 & 0.0001 & 0.0001 & 0.0002 \\
\hline FR & 0.0014 & 0.0003 & 0.0017 & 0.0003 & 0.0002 & 0.0001 & 0.0004 & 0.0001 \\
\hline $\mathrm{HU}$ & 0.0037 & 0.0006 & 0.0052 & 0.0006 & 0.0005 & 0.0001 & 0.0003 & 0.0001 \\
\hline IE & 0.0036 & 0.0009 & 0.0034 & 0.0010 & 0.0008 & 0.0003 & 0.0005 & 0.0003 \\
\hline IS & 0.0005 & 0.0003 & 0.0000 & 0.0002 & 0.0001 & 0.0002 & 0.0004 & 0.0006 \\
\hline IT & 0.0050 & 0.0006 & 0.0042 & 0.0005 & 0.0008 & 0.0002 & 0.0007 & 0.0001 \\
\hline LT & 0.0039 & 0.0010 & 0.0021 & 0.0011 & 0.0010 & 0.0004 & 0.0006 & 0.0007 \\
\hline $\mathrm{LU}$ & 0.0074 & 0.0015 & 0.0103 & 0.0015 & 0.0012 & 0.0006 & 0.0013 & 0.0004 \\
\hline $\mathrm{LV}$ & 0.0032 & 0.0011 & 0.0019 & 0.0006 & 0.0009 & 0.0005 & 0.0003 & 0.0002 \\
\hline NL & 0.0004 & 0.0002 & 0.0006 & 0.0003 & 0.0000 & 0.0000 & 0.0001 & 0.0001 \\
\hline $\mathrm{NO}$ & 0.0002 & 0.0001 & 0.0004 & 0.0002 & 0.0002 & 0.0001 & 0.0001 & 0.0001 \\
\hline PL & 0.0061 & 0.0007 & 0.0043 & 0.0006 & 0.0014 & 0.0002 & 0.0011 & 0.0002 \\
\hline $\mathrm{PT}$ & 0.0148 & 0.0024 & 0.0113 & 0.0019 & 0.0004 & 0.0002 & 0.0005 & 0.0002 \\
\hline $\mathrm{SE}$ & 0.0003 & 0.0002 & 0.0000 & 0.0000 & 0.0001 & 0.0000 & 0.0000 & 0.0001 \\
\hline SI & 0.0015 & 0.0004 & 0.0015 & 0.0004 & 0.0003 & 0.0001 & 0.0004 & 0.0001 \\
\hline SK & 0.0003 & 0.0001 & 0.0014 & 0.0004 & 0.0001 & 0.0000 & 0.0002 & 0.0001 \\
\hline UK & 0.0016 & 0.0004 & 0.0015 & 0.0005 & 0.0007 & 0.0003 & 0.0007 & 0.0002 \\
\hline
\end{tabular}




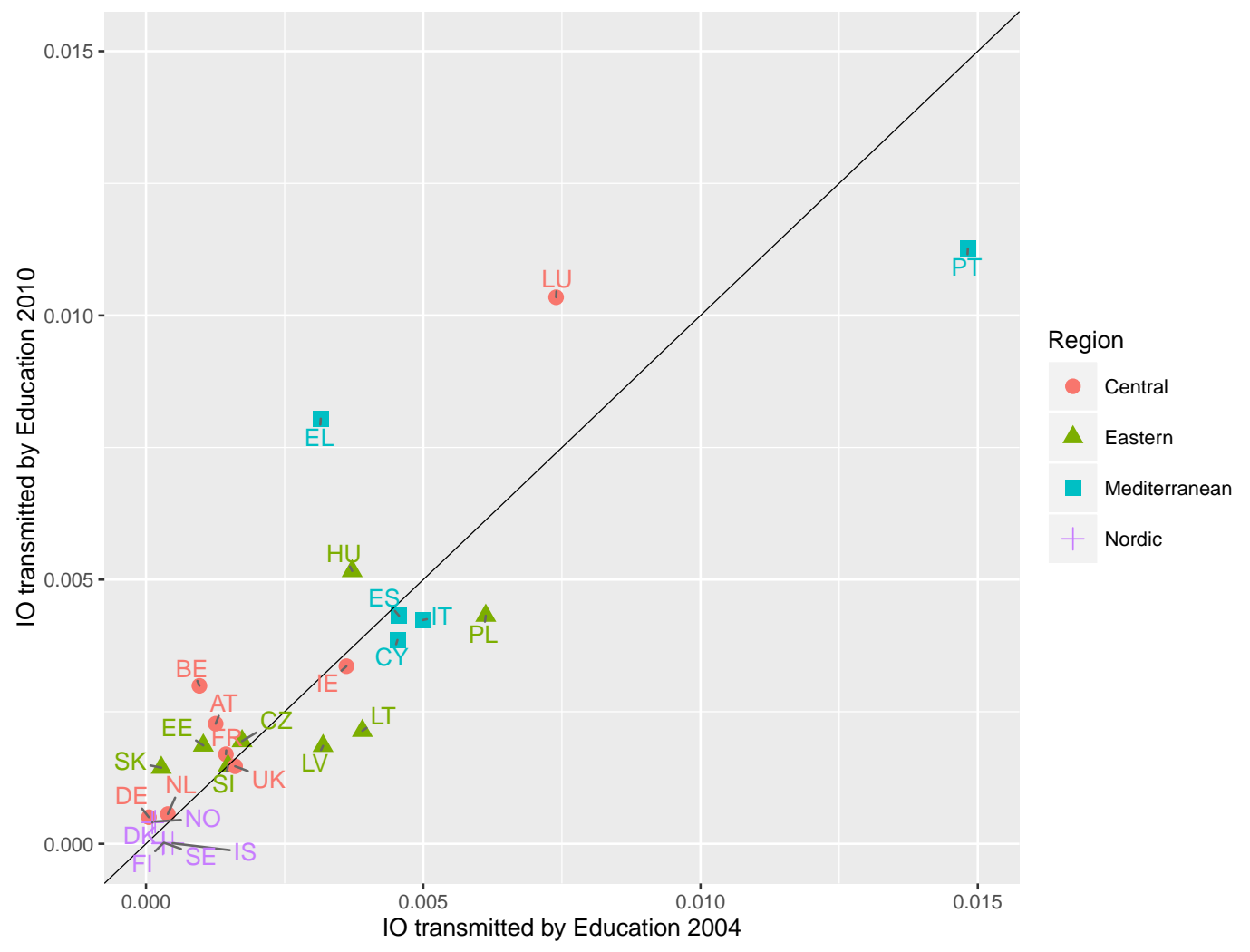

Figure 9: Inequality of Opportunity channelled through Education in Europe - 2004 and 2010. 


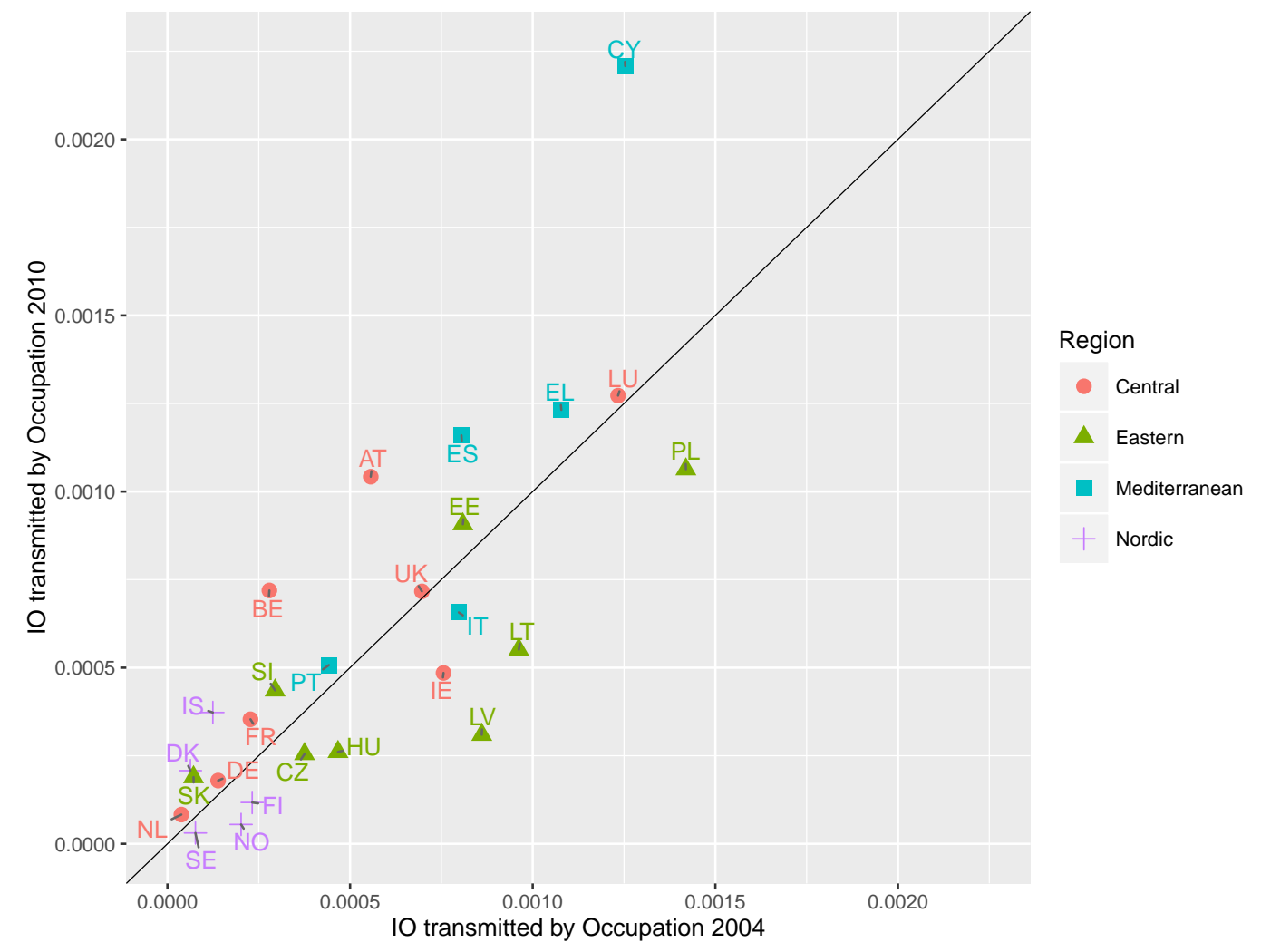

Figure 10: Inequality of Opportunity channelled through Occupation in Europe - 2004 and 2010. 
Table 4: Shares of the sample population with low and high education levels.

Share with low Education Share with high education

\begin{tabular}{ccccc} 
& \multicolumn{2}{c}{$($ ISCED 0,1 and 2$)(\%)$} & \multicolumn{2}{c}{ (ISCED 5 and 6$)(\%)$} \\
\hline Country & 2004 & 2010 & 2004 & 2010 \\
\hline AT & 11.96 & 10.30 & 21.30 & 24.53 \\
BE & 21.06 & 15.30 & 40.94 & 48.60 \\
CY & 26.32 & 20.71 & 30.88 & 36.37 \\
CZ & 6.66 & 3.95 & 15.87 & 18.86 \\
DE & 4.01 & 3.70 & 45.44 & 46.00 \\
DK & 16.15 & 10.05 & 35.78 & 44.71 \\
EE & 8.07 & 9.75 & 28.29 & 33.42 \\
EL & 37.41 & 26.32 & 23.32 & 29.09 \\
ES & 44.69 & 39.28 & 31.03 & 36.47 \\
FI & 10.89 & 6.30 & 42.98 & 49.40 \\
FR & 21.77 & 13.72 & 29.76 & 38.76 \\
HU & 20.88 & 14.86 & 16.31 & 23.98 \\
IE & 31.56 & 19.67 & 34.50 & 50.25 \\
IS & 22.97 & 18.35 & 29.28 & 38.92 \\
IT & 40.50 & 34.10 & 13.94 & 18.92 \\
LT & 4.42 & 6.48 & 26.96 & 34.06 \\
LU & 32.63 & 33.25 & 31.63 & 31.61 \\
LV & 10.40 & 12.54 & 22.84 & 31.62 \\
NL & 16.13 & 11.28 & 40.23 & 45.27 \\
NO & 4.45 & 10.61 & 39.90 & 48.73 \\
PL & 11.24 & 7.41 & 15.91 & 23.39 \\
PT & 72.48 & 64.15 & 13.24 & 16.78 \\
SE & 8.34 & 3.59 & 33.97 & 45.08 \\
SI & 18.05 & 11.75 & 14.23 & 30.86 \\
SK & 4.84 & 2.83 & 18.45 & 25.18 \\
UK & 9.25 & 7.33 & 45.17 & 46.00 \\
\hline & & & &
\end{tabular}




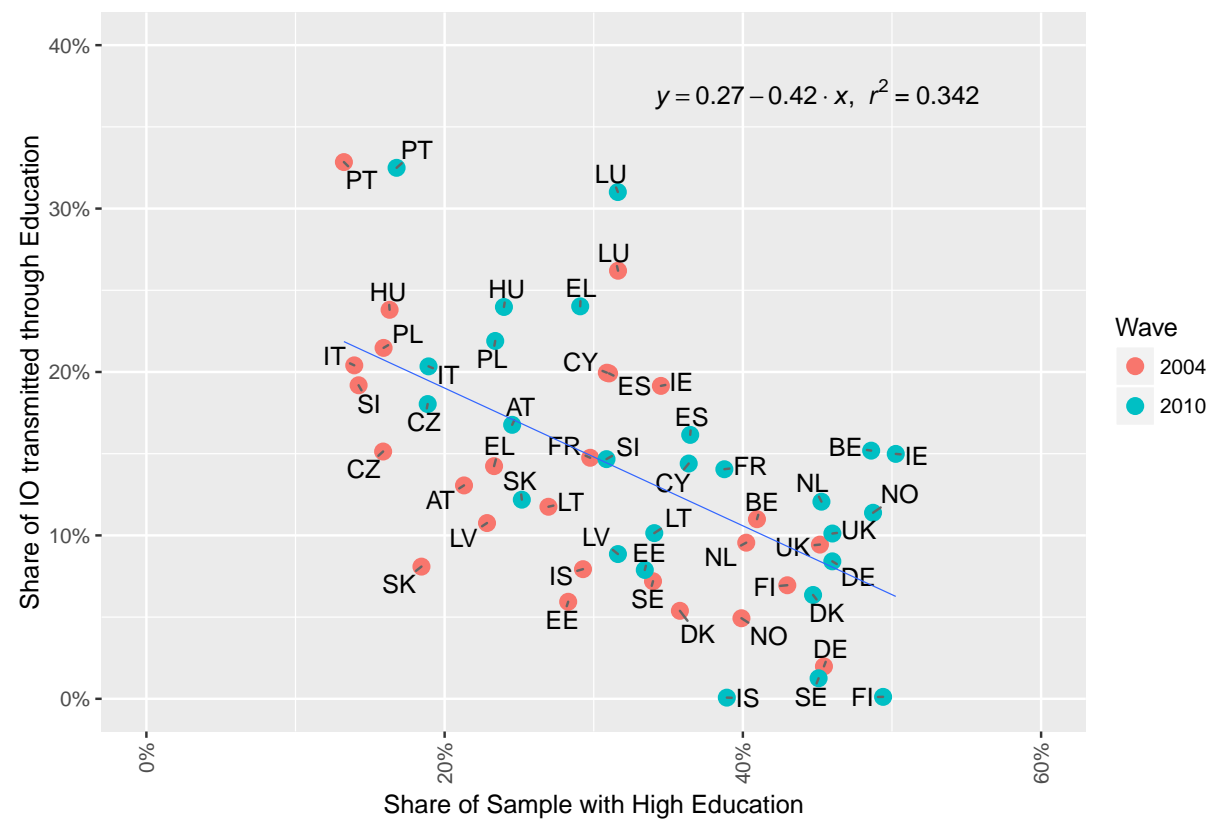

Figure 11: Share of population with high education and share of IO channelled through education.

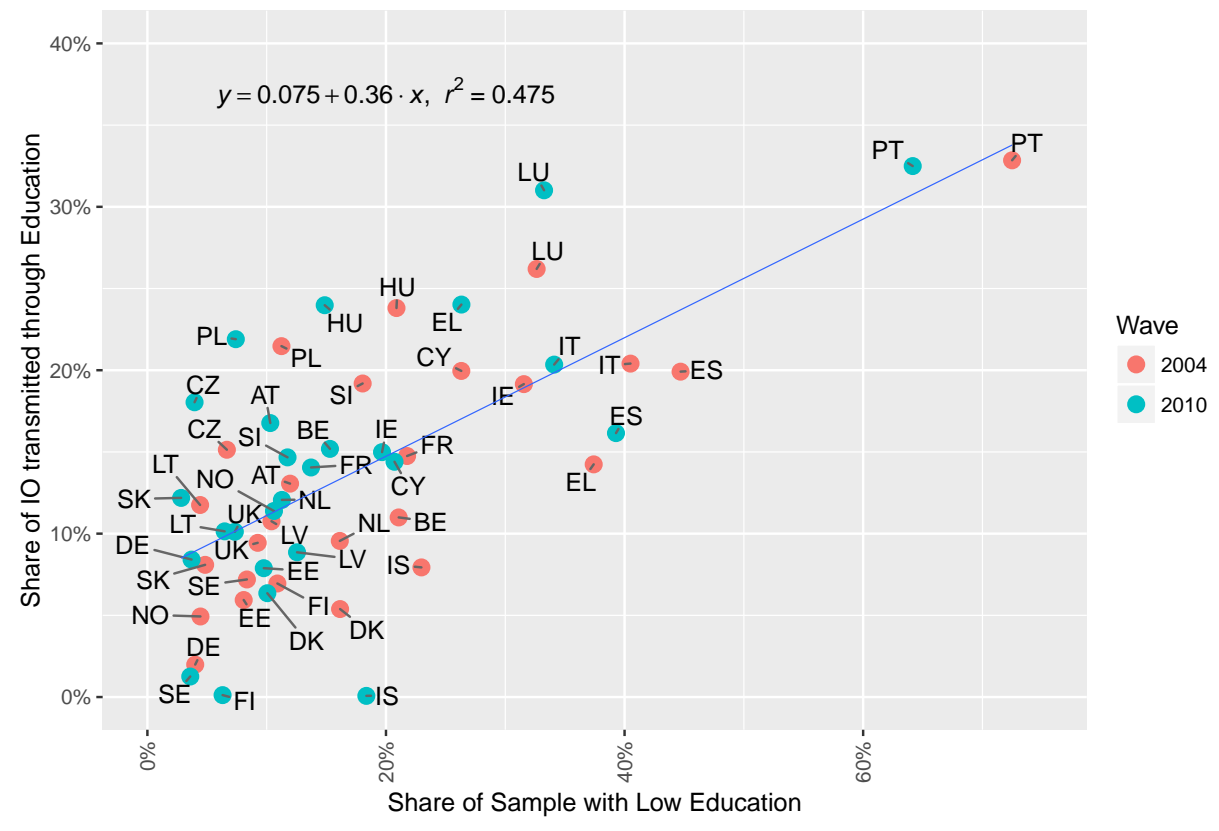

Figure 12: Share of population with low education and share of IO channelled through education. 


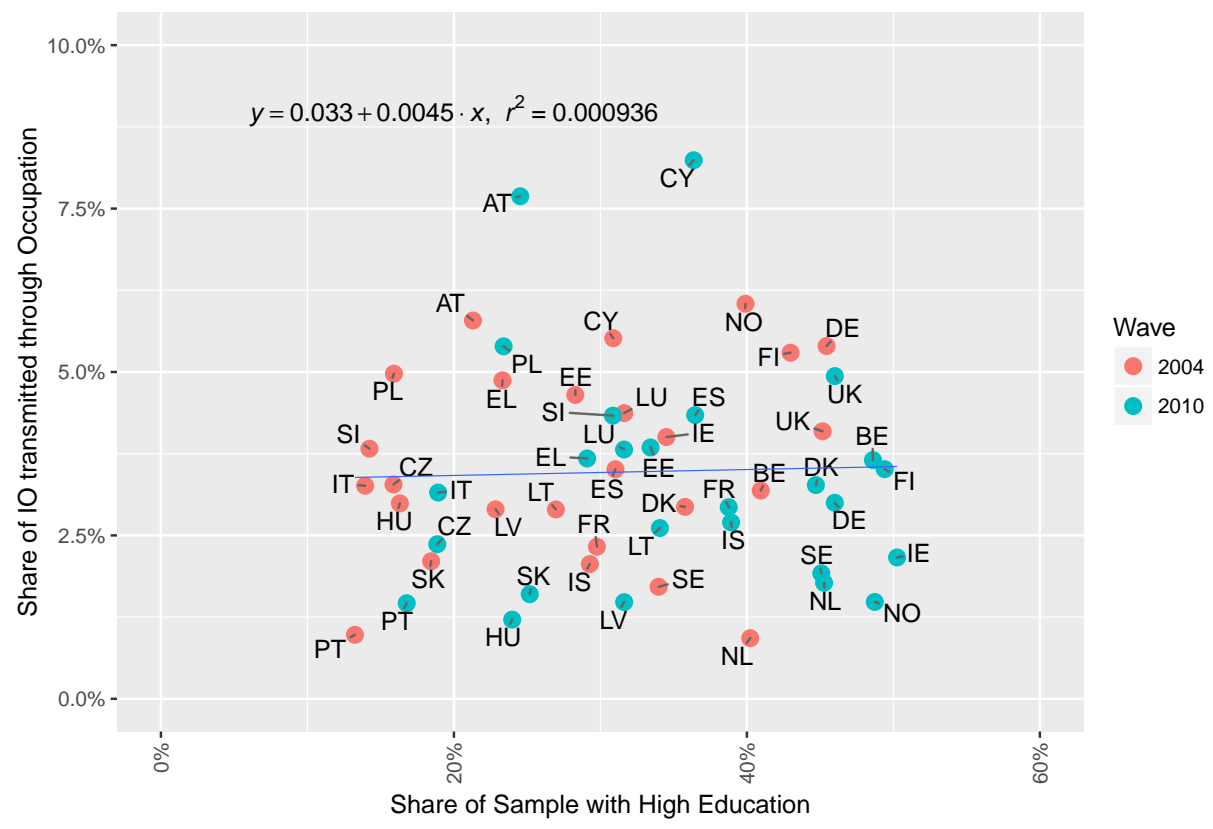

Figure 13: Share of population with high education and share of IO channelled through occupation.

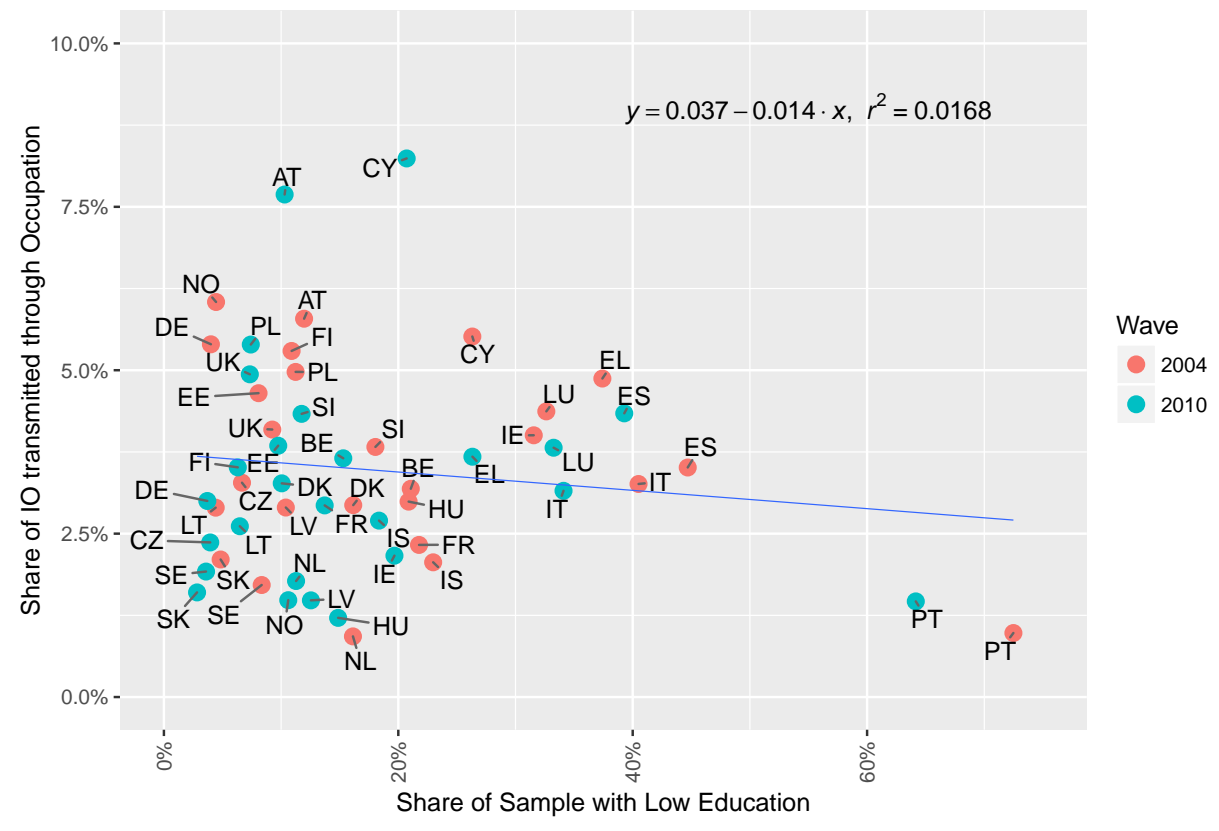

Figure 14: Share of population with low education and share of IO channelled through occupation. 


\section{Appendix I: Decomposing ex-post IO channels}

\section{The hybrid ex post-ex ante method}

Our strategy could potentially be applied to the version of the ex-post approach proposed by Checchi and Peragine (2010). This approach partitions the population in $p$ tranches (groups of people belonging to different types but exerting the same level of effort), and then re-scales each tranche distribution in such a way that all tranches have the same mean as the overall distribution (see Checchi and Peragine (2010, p.436):

$$
y_{i}^{W}=y_{i}^{p} \frac{\bar{Y}}{\bar{y}^{p}}, \forall i, p
$$

where $y_{i}^{W}$ is the re-scaled income of individual $i$ belonging to tranche $p . \bar{Y}$ and $\bar{y}^{p}$ are the overall mean and the $p$ tranche mean, respectively. The complete re-scaled distribution $y^{W}$ thus eliminates all differences between tranches (effort) and retains only differences due to circumstances, which makes it equivalent to our smoothed distribution and $y^{W}=y^{C} .{ }^{26}$

Based on that distribution, the second step of our methodology could be applied, and the role of the channeling variables could be measured just as described in section 2.2. This would formally be a hybrid method in which $y^{C}=y \mid C$ is estimated ex-post (i.e. assuming that people with the same level of effort belonging to different types should have the same mean income), but the channeling role of the education (or other mediating factors) is estimated ex-ante, ie., assuming groups of people with different levels of education should have the same mean 'circumstance conditioned income' and measuring the educational IO channel as the deviation from that assumption.

\footnotetext{
${ }^{26}$ Note that, in the absence of any objective measure of effort (as is usually the case) estimates are obtained under the assumption that all individuals in the same income quantile at different types have exerted the same level of effort and belong to the same tranche.
} 


\section{The ex-post decomposition}

Alternatively, the above mentioned ex-post method could be adapted and used again to partition $y^{W}$ in tranches using the individual education level information. A tranche $f$ would in this case be a group of people having different levels of education but exerting the same level of effort (proxied again by the division in deciles, percentiles, etc.). Each tranche distribution would then be re-scaled again so all tranches have the same overall mean (implying that all effort differences have been equalized and that differences can only be attributed to the different level of education).

$$
y_{i}^{W-E D U}=y_{i}^{W f} \frac{\overline{Y^{W}}}{\overline{y^{W}}}, \forall i, f,
$$

where $y_{i}^{W-E D U}$ is the re-scaled circumstance condition income $y_{i}{ }^{C}=y_{i}{ }^{W}$ of individual $i$ belonging to tranche $f . \overline{Y^{W}}$ and $\bar{y}^{f}$ are the overall mean and the $f$ tranche mean, respectively. Thus, the inequality of this twice re-scaled distribution would be the part of IO channelled by education.

If we intend to analyse the channeling role of a second variable once education has been taken into account, we will use the re-scaled distribution $y^{W}$ that retained only differences due to circumstances, and will transform it in such a way that all types (made according to the levels of the first channel considered) belonging to the same tranche have the same mean. This way we eliminate the differences attributable to the first channel (e.g. education). Secondly, we would proceed to re-scale once again this very new distribution in the way described in the paragraph above, using in this case the new channeling variable (eg. occupation). The inequality of this last distribution would be the component of IO channelled by occupation once education has been accounted for. 


\section{Appendix II: Data and Figures}

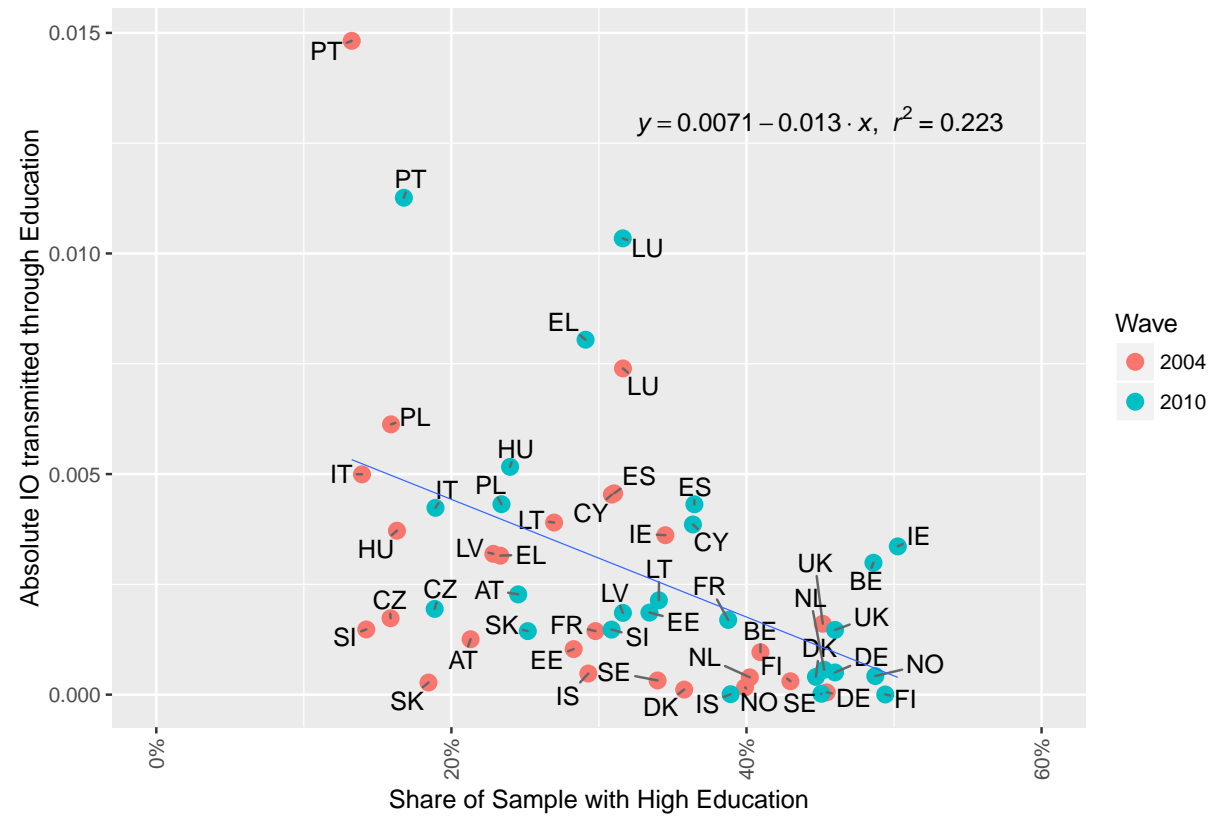

Figure A1: Share of population with high education and level of IO channelled through education.

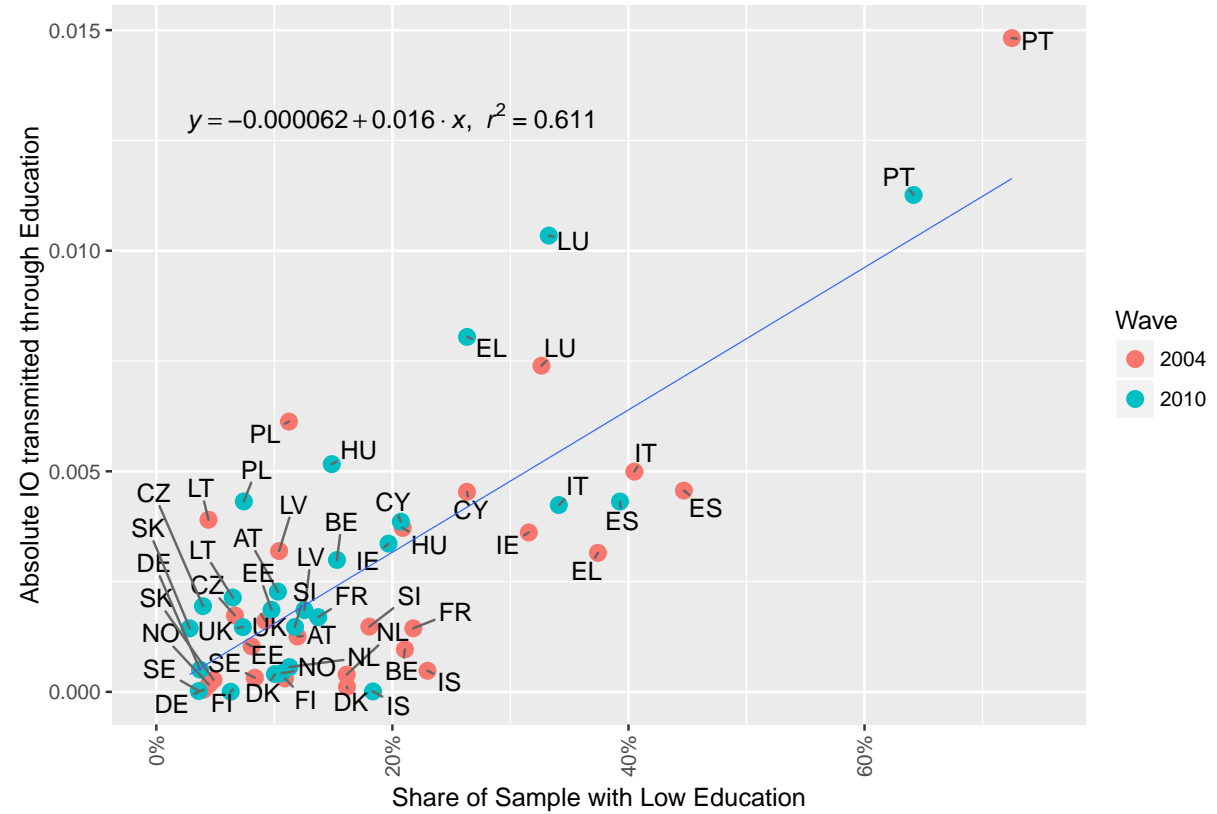

Figure A2: Share of population with low education and level of IO channelled through education. 


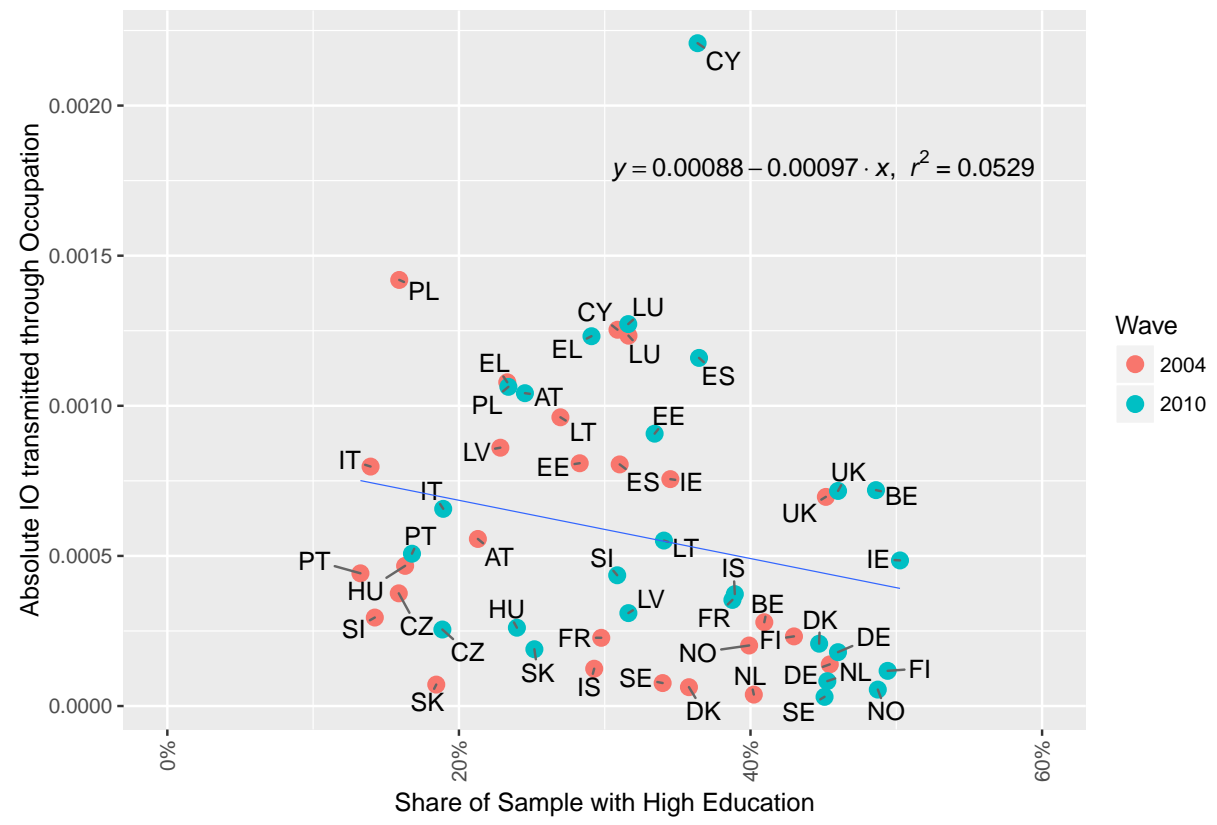

Figure A3: Share of population with high education and level of IO channelled through occupation.

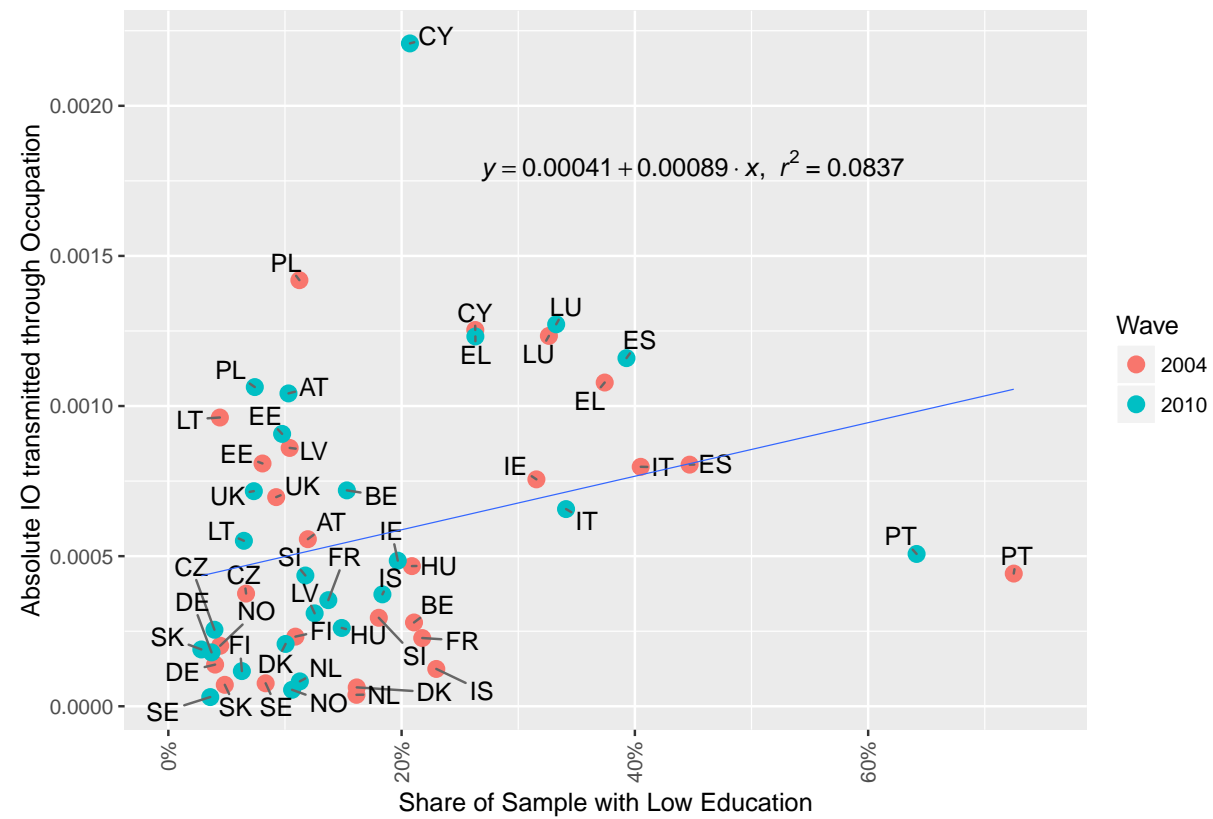

Figure A4: Share of population with low education and level of IO channelled through occupation 
Table A1: Descriptive values of variables and shares of each category (in percentage) - 2005

\begin{tabular}{|c|c|c|c|c|c|c|c|c|c|}
\hline & AT & $\mathrm{BE}$ & $\mathrm{CY}$ & $\mathrm{CZ}$ & $\mathrm{DE}$ & DK & $\mathrm{EE}$ & EL & $\mathrm{ES}$ \\
\hline Observations & 1831 & 2032 & 1995 & 1726 & 5238 & 1814 & 1796 & 2582 & 6417 \\
\hline Income Mean & 19722.89 & 19043.57 & 15323.20 & 4898.51 & 20127.62 & 25831.25 & 3490.09 & 11528.29 & 12746.60 \\
\hline Income Standard Deviation & 9287.79 & 7884.80 & 7662.01 & 2299.47 & 9669.37 & 7723.85 & 2132.86 & 7351.99 & 7797.20 \\
\hline
\end{tabular}

Father Education Level

\begin{tabular}{|c|c|c|c|c|c|c|c|c|c|}
\hline Less than Primary Education (ISCED 0) & & 13.39 & 29.22 & & & & 0.89 & 26.92 & 22.83 \\
\hline Low Education (ISCED 1 or 2 ) (*) & 57.56 & 47.83 & 48.27 & 16.74 & 13.40 & 39.47 & 45.66 & 59.22 & 62.09 \\
\hline Middle Education (ISCED 3 or 4 ) & 38.67 & 22.83 & 15.59 & 74.57 & 53.04 & 43.77 & 39.20 & 8.09 & 5.75 \\
\hline High Education (ISCED 5 or 6 ) & 3.77 & 15.94 & 6.92 & 8.69 & 33.56 & 16.76 & 14.25 & 5.77 & 9.33 \\
\hline
\end{tabular}

High Education (ISCED 5 or 6 )

Mother's Education Level

\begin{tabular}{|c|c|c|c|c|c|c|c|c|c|}
\hline Less than Primary Education (ISCED 0) & & 14.71 & 38.80 & & & & 1.34 & 32.49 & 26.04 \\
\hline Low Education (ISCED 1 or 2$)(*)$ & 74.17 & 55.22 & 45.81 & 35.23 & 35.59 & 59.76 & 45.60 & 57.71 & 65.78 \\
\hline Middle Education (ISCED 3 or 4 ) & 23.21 & 19.93 & 11.78 & 60.72 & 53.13 & 26.90 & 37.69 & 7.01 & 4.25 \\
\hline High Education (ISCED 5 or 6 ) & 2.62 & 10.14 & 3.61 & 4.06 & 11.28 & 13.34 & 15.37 & 2.79 & 3.93 \\
\hline
\end{tabular}

Father Occupational Category

\begin{tabular}{|c|c|c|c|c|c|c|c|c|c|}
\hline Managerial & 4.26 & 10.33 & 0.85 & 4.46 & 6.68 & 8.54 & 9.35 & 10.50 & 6.40 \\
\hline Professional & 3.06 & 9.94 & 5.11 & 5.85 & 14.87 & 12.13 & 7.35 & 4.26 & 3.85 \\
\hline Technical & 11.52 & 6.15 & 4.81 & 15.12 & 11.42 & 9.70 & 4.96 & 1.98 & 4.64 \\
\hline Clerical & 5.52 & 9.84 & 4.16 & 3.01 & 7.37 & 4.91 & 1.17 & 5.38 & 5.33 \\
\hline Sales & 10.60 & 5.36 & 11.98 & 3.59 & 2.98 & 5.18 & 1.06 & 4.26 & 7.36 \\
\hline Skilled Agricultural (*) & 12.89 & 4.53 & 18.40 & 5.74 & 5.61 & 13.29 & 3.23 & 37.10 & 15.04 \\
\hline Craft Trade & 27.69 & 23.57 & 23.86 & 35.86 & 30.95 & 22.71 & 29.12 & 17.78 & 24.40 \\
\hline Machine operation & 7.65 & 7.78 & 10.88 & 18.02 & 10.88 & 7.99 & 31.90 & 7.47 & 11.10 \\
\hline Elementary & 16.49 & 10.09 & 19.10 & 6.78 & 5.15 & 12.62 & 9.91 & 9.80 & 19.71 \\
\hline Armed/Military & 0.05 & 2.26 & 0.35 & 1.33 & 1.15 & 0.83 & 1.73 & 1.16 & 1.85 \\
\hline Unemployed & 0.27 & 10.14 & 0.50 & 0.23 & 2.94 & 2.09 & 0.22 & 0.31 & 0.31 \\
\hline \multicolumn{10}{|l|}{ Economic difficulties in childhood } \\
\hline Very often & & 3.84 & 5.96 & 4.63 & & 2.54 & 3.17 & & 8.73 \\
\hline Often & & 5.91 & 16.99 & 9.50 & & 4.80 & 12.69 & & 9.30 \\
\hline Occasionally & & 12.84 & 40.05 & 28.10 & & 14.83 & 36.14 & & 20.29 \\
\hline Rarely (*) & & 11.71 & 29.87 & 25.26 & & 18.14 & 22.49 & & 20.65 \\
\hline Never & & 65.40 & 7.12 & 32.21 & & 59.21 & 25.50 & & 39.58 \\
\hline \multicolumn{10}{|l|}{ Gender } \\
\hline Woman & 38.83 & 40.40 & 38.65 & 41.89 & 48.42 & 51.16 & 47.55 & 36.64 & 37.35 \\
\hline $\operatorname{Man}(*)$ & 61.17 & 59.60 & 61.35 & 58.11 & 51.58 & 48.84 & 52.45 & 63.36 & 62.65 \\
\hline \multicolumn{10}{|l|}{ Country of birth } \\
\hline Local (*) & 88.09 & 89.91 & 85.21 & 97.10 & 95.42 & 97.52 & 87.92 & 91.29 & 94.00 \\
\hline Other EU & 2.57 & 4.92 & 4.86 & 1.91 & & 0.72 & & 1.90 & 1.29 \\
\hline Other & 9.28 & 4.82 & 9.92 & 0.98 & 4.58 & 1.76 & 12.08 & 6.82 & 4.71 \\
\hline \multicolumn{10}{|l|}{ Adult Child Education Level } \\
\hline Pre-primary (ISCED 0) & & 0.64 & 0.50 & & & & & & \\
\hline Primary (ISCED 1) & 0.16 & 6.94 & 14.59 & 0.06 & 0.40 & 0.06 & 0.45 & 25.41 & 20.76 \\
\hline Low secondary (ISCED 2) & 11.80 & 13.48 & 11.23 & 6.60 & 3.61 & 16.10 & 7.63 & 12.01 & 23.94 \\
\hline High Secondary (ISCED 3) (*) & 55.54 & 35.58 & 40.50 & 76.01 & 41.35 & 48.07 & 53.51 & 34.90 & 22.38 \\
\hline Post Secondary non-tertiary (ISCED 4) & 11.20 & 2.41 & 2.31 & 1.45 & 9.20 & & 10.13 & 4.38 & 1.90 \\
\hline Tertiary (ISCED 5 and 6) & 21.30 & 40.94 & 30.88 & 15.87 & 45.44 & 35.78 & 28.29 & 23.32 & 31.03 \\
\hline \multicolumn{10}{|l|}{ Adult Child Occupational Category } \\
\hline Managerial & 5.52 & 9.65 & 2.06 & 6.03 & 4.26 & 6.67 & 12.92 & 7.67 & 5.33 \\
\hline Professional & 8.25 & 16.98 & 13.08 & 10.25 & 21.67 & 17.36 & 11.75 & 13.83 & 12.31 \\
\hline Technical & 16.00 & 12.89 & 14.84 & 22.19 & 28.22 & 25.63 & 11.47 & 8.56 & 9.88 \\
\hline Clerical & 15.02 & 20.08 & 11.43 & 7.82 & 16.25 & 10.58 & 3.62 & 11.54 & 10.88 \\
\hline Sales & 20.04 & 9.01 & 17.14 & 11.94 & 8.72 & 13.23 & 11.19 & 13.09 & 14.54 \\
\hline Skilled Agricultural (*) & 2.46 & 0.98 & 1.25 & 2.03 & 1.34 & 1.82 & 3.90 & 11.15 & 3.43 \\
\hline Craft Trade & 15.95 & 13.63 & 16.84 & 21.90 & 10.46 & 11.74 & 17.37 & 17.62 & 17.67 \\
\hline Machine operation & 5.63 & 6.59 & 6.07 & 11.18 & 4.22 & 5.24 & 19.04 & 8.06 & 8.29 \\
\hline Elementary & 10.60 & 10.19 & 15.79 & 6.26 & 4.60 & 7.17 & 8.30 & 7.51 & 16.86 \\
\hline Armed/Military & 0.55 & & 1.50 & 0.41 & 0.27 & 0.55 & 0.45 & 0.97 & 0.81 \\
\hline
\end{tabular}

Table A1.A Descriptive values of variables and shares of each category (in percentage) - 2005 


\begin{tabular}{|c|c|c|c|c|c|c|c|c|c|}
\hline & FI & FR & $\mathrm{HU}$ & $\mathrm{IE}$ & IS & IT & LT & $\mathrm{LU}$ & $\mathrm{LV}$ \\
\hline Obs & 3020 & 4052 & 2888 & 2139 & 888 & 10373 & 2014 & 1799 & 1471 \\
\hline Income Mean & 21670.10 & 18471.30 & 3812.88 & 23211.82 & 26021.48 & 17355.22 & 2622.03 & 32487.55 & 2737.68 \\
\hline Income Standard Deviation & 9720.17 & 8996.01 & 1824.00 & 12595.40 & 9933.90 & 9183.99 & 1777.92 & 16962.61 & 1926.07 \\
\hline
\end{tabular}

Father Education Level

Less than Primary Education (ISCED 0)

Low Education (ISCED 1 or 2$)(*)$

High Education (ISCED 5 or 6 )

$\begin{array}{lll}0.23 & 5.77 & 1.18\end{array}$

62.59

$\begin{array}{ll}.18 & 2.38 \\ 4.39 & 78.78\end{array}$

$\begin{array}{ll}2.38 & 2.59 \\ 78.78 & 34.66\end{array}$

$\begin{array}{cc}2.59 & 14.16 \\ 34.46 & 70.78\end{array}$

5.81
60.72

60.72

24.53
8.94

6.34

52.14

16.85

8.69

8.10

10.38
8.46

50.45
12.50

3.47

13.67

33.85

Mother's Education Level

Less than Primary Education (ISCED 0)

Middle Education (ISCED 3 or 4 )

High Education (ISCED 5 or 6 )

$\begin{array}{ccccccccc}0.17 & 6.89 & 1.56 & 1.96 & 2.59 & 18.47 & 7.45 & 8.28 & 2.24 \\ 67.68 & 70.95 & 60.94 & 77.09 & 66.44 & 71.77 & 58.39 & 65.54 & 48.81 \\ 20.53 & 16.16 & 33.21 & 14.03 & 25.23 & 8.58 & 25.77 & 18.07 & 37.87 \\ 11.62 & 6.00 & 4.29 & 6.92 & 5.74 & 1.18 & 8.39 & 8.12 & 11.08\end{array}$

Father Occupational Category

\begin{tabular}{|c|c|c|c|c|c|c|c|c|c|}
\hline Managerial & 9.21 & 7.97 & 5.47 & 25.06 & 19.71 & 8.51 & 4.87 & 8.45 & 6.12 \\
\hline Professional & 5.50 & 8.93 & 5.64 & 8.23 & 10.70 & 3.51 & 7.40 & 9.78 & 8.23 \\
\hline Technical & 10.43 & 8.02 & 5.30 & 2.95 & 9.80 & 7.06 & 3.28 & 12.90 & 5.64 \\
\hline Clerical & 1.66 & 5.26 & 3.50 & 5.66 & 1.58 & 5.50 & 2.04 & 4.78 & 1.56 \\
\hline Sales & 3.68 & 3.01 & 3.15 & 5.28 & 5.97 & 4.02 & 1.74 & 3.17 & 2.31 \\
\hline Skilled Agricultural (*) & 23.87 & 12.83 & 11.70 & 1.36 & 19.93 & 12.42 & 6.06 & 11.06 & 2.45 \\
\hline Craft Trade & 19.87 & 24.43 & 34.28 & 18.61 & 21.51 & 26.91 & 26.07 & 21.85 & 27.60 \\
\hline Machine operation & 15.76 & 18.51 & 16.45 & 10.19 & 6.19 & 14.02 & 23.93 & 22.40 & 28.82 \\
\hline Elementary & 3.11 & 7.38 & 11.39 & 17.06 & 3.60 & 11.96 & 22.79 & 4.34 & 14.28 \\
\hline Armed/Military & 0.66 & 3.41 & 1.87 & 1.73 & 0.11 & 1.77 & 0.94 & 1.06 & 2.11 \\
\hline Unemployed & 6.26 & 0.25 & 1.25 & 3.88 & 0.90 & 4.32 & 0.89 & 0.22 & 0.88 \\
\hline
\end{tabular}

Unemployed

0.90

0.89

0.22

0.88

Economic difficulties in childhood

\begin{tabular}{|c|c|c|c|c|c|c|c|c|c|}
\hline Very often & 5.86 & & 10.80 & 7.90 & 2.93 & 14.39 & 8.39 & 6.61 & 5.71 \\
\hline Often & 8.38 & & 17.38 & 8.51 & 4.17 & 21.06 & 17.68 & 10.56 & 12.85 \\
\hline Occasionally & 25.43 & & 15.51 & 22.44 & 14.53 & 30.36 & 29.00 & 19.79 & 26.78 \\
\hline Rarely (*) & 23.08 & & 32.86 & 23.00 & 14.41 & 19.04 & 18.67 & 16.23 & 17.54 \\
\hline Never & 35.30 & & 22.75 & 37.68 & 63.29 & 15.15 & 25.87 & 45.53 & 35.83 \\
\hline \multicolumn{10}{|l|}{ Gender } \\
\hline Woman & 48.21 & 42.92 & 45.64 & 59.19 & 49.10 & 37.48 & 51.79 & 37.52 & 50.44 \\
\hline $\operatorname{Man}(*)$ & 51.79 & 57.08 & 54.36 & 40.81 & 50.90 & 62.52 & 48.21 & 62.48 & 49.56 \\
\hline \multicolumn{10}{|l|}{ Country of birth } \\
\hline Local $\left(^{*}\right)$ & 98.81 & 87.88 & 97.54 & 87.52 & 95.27 & 93.38 & 93.74 & 49.31 & 85.32 \\
\hline Other EU & 0.66 & 3.87 & 0.35 & 9.35 & 2.48 & 1.37 & 0.40 & 42.47 & \\
\hline Other & 0.43 & 8.24 & 2.11 & 3.13 & 2.25 & 5.13 & 5.86 & 8.06 & 14.68 \\
\hline \multicolumn{10}{|l|}{ Adult Child Education Level } \\
\hline Pre-primary (ISCED 0) & & 0.89 & 0.14 & & & 0.52 & & & 0.14 \\
\hline Primary (ISCED 1) & & 6.10 & 0.93 & 12.25 & 0.45 & 7.29 & 0.15 & 22.68 & 7.14 \\
\hline Low secondary (ISCED 2) & 10.89 & 14.78 & 19.81 & 19.31 & 22.52 & 32.69 & 4.27 & 9.95 & 3.13 \\
\hline High Secondary (ISCED 3) $\left(^{*}\right)$ & 45.79 & 48.47 & 62.81 & 23.00 & 38.29 & 38.42 & 35.65 & 33.07 & 54.11 \\
\hline Post Secondary non-tertiary (ISCED 4) & 0.33 & & & 10.94 & 9.46 & 7.14 & 32.97 & 2.67 & 12.64 \\
\hline Tertiary (ISCED 5 and 6) & 42.98 & 29.76 & 16.31 & 34.50 & 29.28 & 13.94 & 26.96 & 31.63 & 22.84 \\
\hline \multicolumn{10}{|l|}{ Adult Child Occupational Category } \\
\hline Managerial & 15.46 & 8.12 & 9.38 & 16.27 & 15.32 & 7.16 & 8.44 & 6.61 & 10.20 \\
\hline Professional & 17.28 & 13.52 & 9.73 & 18.61 & 18.13 & 8.47 & 18.02 & 19.01 & 11.28 \\
\hline Technical & 15.56 & 18.07 & 10.84 & 5.61 & 17.57 & 21.10 & 8.44 & 21.68 & 12.85 \\
\hline Clerical & 6.52 & 12.49 & 8.17 & 14.31 & 9.23 & 11.94 & 3.87 & 13.29 & 5.57 \\
\hline Sales & 12.52 & 10.88 & 11.95 & 17.16 & 12.39 & 10.52 & 10.58 & 9.45 & 11.76 \\
\hline Skilled Agricultural (*) & 10.17 & 3.80 & 3.39 & 0.42 & 6.53 & 2.18 & 6.70 & 2.83 & 3.40 \\
\hline Craft Trade & 10.50 & 11.50 & 22.09 & 7.95 & 12.84 & 17.43 & 21.55 & 10.89 & 16.86 \\
\hline Machine operation & 6.36 & 10.61 & 11.70 & 7.15 & 3.15 & 10.49 & 11.42 & 6.39 & 14.41 \\
\hline Elementary & 4.93 & 9.58 & 11.84 & 12.11 & 4.84 & 9.33 & 10.82 & 9.56 & 13.19 \\
\hline Armed/Military & 0.70 & 1.43 & 0.90 & 0.42 & & 1.37 & 0.15 & 0.28 & 0.48 \\
\hline
\end{tabular}

Table A1.B Descriptive values of variables and shares of each category (in percentage) - 2005 (cont.) 


\begin{tabular}{lcccccccc}
\hline & NL & NO & PL & PT & SE & SI & SK & UK \\
\hline Observations & 2573 & 1664 & 7796 & 1948 & 1822 & 2333 & 2624 & 1687 \\
Income Mean & 20102.14 & 30139.73 & 2958.35 & 9474.34 & 20144.79 & 10138.65 & 3082.21 & 26498.48 \\
Income Standard Deviation & 8007.64 & 10598.06 & 2108.33 & 6836.42 & 7452.32 & 4129.92 & 1371.77 & 15915.52
\end{tabular}

Father Education Level

Less than Primary Education (ISCED 0)

Low Education (ISCED 1 or 2) (*)

Middle Education (ISCED 3 or 4)

High Education (ISCED 5 or 6 )

62.22

19.08

18.69

46.63
23.26

13.24

43.02

38.85
4.89

35.88

$58.32-71.19$

2.82

2.98

12.79

14.71

42.26

3.51

34.95

55.75

9.30

Mother's Education Level

Less than Primary Education (ISCED 0)

Low Education (ISCED 1 or 2 ) $\left(^{*}\right.$ )

Middle Education (ISCED 3 or 4)

High Education (ISCED 5 or 6 )

$\begin{array}{cccccccc}78.78 & 36.06 & 47.88 & 46.61 & 2.03 & 5.87 & & 55.96 \\ 13.99 & 35.88 & 33.79 & 1.59 & 13.05 & 63.14 & 51.07 & 17.96 \\ 7.23 & 28.06 & 3.27 & 3.03 & 11.36 & 29.66 & 45.08 & 9.66 \\ & & & & & & & \end{array}$

Father Occupational Category

\begin{tabular}{lcccccccc}
\hline Managerial & 22.50 & 12.02 & 2.94 & 6.31 & 1.32 & 3.77 & 7.66 & 5.93 \\
Professional & 10.73 & 8.65 & 3.85 & 2.10 & 2.69 & 4.46 & 6.75 & 9.90 \\
Technical & 13.41 & 17.97 & 5.84 & 3.39 & 2.74 & 9.86 & 9.79 & 7.47 \\
Clerical & 6.30 & 4.39 & 2.95 & 5.60 & 1.48 & 4.89 & 2.90 & 18.97 \\
Sales & 3.93 & 4.81 & 2.10 & 5.95 & 1.37 & 5.36 & 2.82 & 22.47 \\
Skilled Agricultural $\left(^{*}\right)$ & 1.98 & 10.52 & 27.41 & 23.82 & 1.87 & 15.00 & 3.16 & 0.59 \\
Craft Trade & 20.44 & 23.74 & 27.64 & 27.36 & 7.85 & 27.05 & 27.06 & 1.54 \\
Machine operation & 9.52 & 14.60 & 15.41 & 11.04 & 3.29 & 21.95 & 21.57 & 10.20 \\
Elementary & 4.12 & 0.96 & 9.04 & 13.04 & 0.27 & 6.09 & 15.59 & 19.15 \\
Armed/Military & 1.48 & 1.14 & 1.56 & 1.33 & 0.44 & 0.90 & & \\
Unemployed & 5.60 & 1.20 & 1.26 & 0.05 & 1.81 & 0.69 & 2.71 & 3.79
\end{tabular}

Unemployed

Economic difficulties in childhood

\begin{tabular}{|c|c|c|c|c|c|c|c|c|}
\hline Very often & 2.68 & 1.74 & 8.80 & & 3.73 & 11.96 & 21.76 & 7.65 \\
\hline Often & 7.00 & 4.21 & 15.74 & & 5.87 & 22.12 & 27.21 & 9.25 \\
\hline Occasionally & 14.61 & 11.96 & 30.52 & & 13.01 & 32.62 & 33.08 & 22.05 \\
\hline Rarely $(*)$ & 18.23 & 26.62 & 15.03 & & 20.75 & 17.49 & 14.25 & 18.26 \\
\hline Never & 54.06 & 54.21 & 27.95 & & 54.50 & 15.52 & 3.43 & 36.16 \\
\hline \multicolumn{9}{|l|}{ Gender } \\
\hline Woman & 52.74 & 47.54 & 45.82 & 40.61 & 50.77 & 51.69 & 43.75 & 51.33 \\
\hline $\operatorname{Man}(*)$ & 47.26 & 52.46 & 54.18 & 59.39 & 49.23 & 48.31 & 56.25 & 48.67 \\
\hline \multicolumn{9}{|l|}{ Country of birth } \\
\hline Local $(*)$ & 95.61 & 93.99 & 99.73 & 97.07 & 87.16 & 89.50 & 98.29 & 92.59 \\
\hline Other EU & 1.32 & 2.94 & 0.06 & 1.28 & 5.21 & & 1.33 & 0.47 \\
\hline Other & 3.07 & 2.94 & 0.21 & 1.64 & 7.63 & 10.50 & 0.38 & 6.94 \\
\hline \multicolumn{9}{|l|}{ Adult Child Education Level } \\
\hline Pre-primary (ISCED 0) & & 0.06 & 0.36 & & & 0.04 & & \\
\hline Primary (ISCED 1) & 2.10 & 0.18 & 10.88 & 57.29 & 0.60 & 15.77 & & \\
\hline Low secondary (ISCED 2) & 14.03 & 4.21 & & 15.20 & 7.74 & 2.23 & 4.84 & 9.25 \\
\hline High Secondary (ISCED 3) $\left(^{*}\right)$ & 40.26 & 51.20 & 69.00 & 14.12 & 47.20 & 60.01 & 76.71 & 42.15 \\
\hline Post Secondary non-tertiary (ISCED 4) & 3.38 & 4.45 & 3.86 & 0.15 & 10.48 & 7.72 & & 3.44 \\
\hline Tertiary (ISCED 5 and 6) & 40.23 & 39.90 & 15.91 & 13.24 & 33.97 & 14.23 & 18.45 & 45.17 \\
\hline \multicolumn{9}{|l|}{ Adult Child Occupational Category } \\
\hline Managerial & 11.43 & 11.30 & 4.46 & 6.31 & 4.67 & 3.94 & 7.70 & 18.08 \\
\hline Professional & 23.28 & 16.29 & 13.33 & 7.80 & 22.61 & 12.52 & 13.19 & 16.00 \\
\hline Technical & 23.36 & 27.76 & 10.34 & 9.39 & 21.41 & 18.05 & 17.99 & 14.64 \\
\hline Clerical & 13.99 & 5.89 & 6.49 & 9.86 & 8.62 & 10.07 & 6.67 & 14.58 \\
\hline Sales & 11.08 & 18.03 & 10.57 & 13.14 & 17.45 & 11.92 & 10.82 & 15.23 \\
\hline Skilled Agricultural (*) & 0.93 & 2.70 & 11.90 & 4.88 & 1.15 & 2.19 & 1.33 & 0.71 \\
\hline Craft Trade & 7.35 & 9.07 & 21.83 & 25.62 & 9.93 & 13.50 & 19.70 & 7.11 \\
\hline Machine operation & 4.39 & 6.01 & 10.40 & 9.96 & 10.70 & 19.03 & 14.94 & 6.82 \\
\hline Elementary & 3.85 & 2.76 & 9.88 & 12.06 & 3.18 & 8.32 & 7.66 & 6.82 \\
\hline Armed/Military & 0.35 & 0.18 & 0.80 & 0.98 & 0.27 & 0.47 & & \\
\hline
\end{tabular}

Table A1.C Descriptive values of variables and shares of each category (in percentage) - 2005 (cont.) 
Table A2: Descriptive values of variables and shares of each category (in percentage) - 2011

\begin{tabular}{|c|c|c|c|c|c|c|c|c|c|}
\hline & AT & $\mathrm{BE}$ & $\mathrm{CY}$ & $\mathrm{CZ}$ & $\mathrm{DE}$ & DK & $\mathrm{EE}$ & EL & $\mathrm{ES}$ \\
\hline Observations & 2699 & 2078 & 1878 & 3011 & 4374 & 1313 & 1876 & 2059 & 5975 \\
\hline Income Mean & 22212.72 & 20671.17 & 17432.12 & 7464.02 & 21280.40 & 29207.95 & 5004.36 & 10476.10 & 12907.89 \\
\hline Income Standard Deviation & 10431.38 & 8922.71 & 8854.89 & 3463.65 & 10381.66 & 10171.59 & 2929.11 & 6059.35 & 7794.01 \\
\hline
\end{tabular}

Father Education Level

\begin{tabular}{|c|c|c|c|c|c|c|c|c|c|}
\hline No Education & 0.37 & 1.92 & 4.53 & 0.17 & 0.25 & & & 4.61 & 3.78 \\
\hline Low Education (ISCED 0,1 , or 2) (*) & 36.94 & 49.86 & 67.09 & 64.50 & 8.96 & 28.41 & 37.15 & 72.17 & 79.46 \\
\hline Middle Education (ISCED 3 or 4 ) & 47.28 & 25.51 & 18.85 & 25.34 & 59.35 & 46.46 & 44.72 & 14.86 & 7.15 \\
\hline High Education (ISCED 5 or 6 ) & 15.41 & 22.71 & 9.53 & 10.00 & 31.44 & 25.13 & 18.12 & 8.35 & 9.61 \\
\hline
\end{tabular}

Mother's Education Level

\begin{tabular}{lcccccccccc}
\hline No Education & 1.33 & 3.32 & 8.25 & 0.23 & 0.66 & 0.05 & 6.65 & 5.96 \\
Low Education (ISCED 0,1, or 2) $(*)$ & 54.72 & 55.25 & 69.44 & 64.20 & 23.34 & 46.69 & 32.36 & 74.60 & 84.27 \\
Middle Education (ISCED 3 or 4) & 38.68 & 24.69 & 17.25 & 30.79 & 63.85 & 32.98 & 46.32 & 14.13 & 5.31 \\
High Education (ISCED 5 or 6) & 5.26 & 16.75 & 5.06 & 4.78 & 12.14 & 20.34 & 21.27 & 4.61 & 4.47
\end{tabular}

Father Occupational Category

\begin{tabular}{|c|c|c|c|c|c|c|c|c|c|}
\hline Managerial & 4.41 & 7.36 & 1.33 & 3.59 & 5.42 & 12.41 & 7.57 & 7.63 & 6.31 \\
\hline Professional & 5.63 & 16.17 & 6.92 & 7.21 & 14.95 & 14.55 & 9.38 & 5.15 & 5.44 \\
\hline Technical & 7.85 & 11.65 & 8.20 & 14.02 & 17.83 & 7.69 & 6.56 & 2.67 & 8.57 \\
\hline Clerical & 6.52 & 9.82 & 3.46 & 3.85 & 5.92 & 4.65 & 1.39 & 8.98 & 5.84 \\
\hline Sales & 15.49 & 5.87 & 9.64 & 3.72 & 6.24 & 11.73 & 1.44 & 4.37 & 9.24 \\
\hline Skilled Agricultural (*) & 13.71 & 5.39 & 15.55 & 3.82 & 4.55 & 12.64 & 4.42 & 32.10 & 13.36 \\
\hline Craft Trade & 29.08 & 22.23 & 25.24 & 33.64 & 26.73 & 28.26 & 24.52 & 20.54 & 19.83 \\
\hline Machine operation & 6.74 & 12.90 & 12.89 & 22.62 & 13.35 & 5.41 & 35.18 & 11.02 & 12.57 \\
\hline Elementary & 7.74 & 4.19 & 14.32 & 4.95 & 2.99 & 0.84 & 6.34 & 5.10 & 14.76 \\
\hline Armed/Military & 0.93 & & 0.64 & 1.33 & & & 1.01 & 1.60 & 1.41 \\
\hline Unemployed & 1.89 & 4.43 & 1.81 & 1.26 & 2.01 & 1.83 & 2.19 & 0.83 & 2.68 \\
\hline \multicolumn{10}{|l|}{ Perceived financial situation in childhood } \\
\hline Very bad & 5.63 & 2.31 & 11.08 & 1.36 & 2.22 & 1.68 & 0.53 & 4.47 & 2.68 \\
\hline Bad & 9.48 & 5.58 & 13.05 & 4.05 & 5.62 & 3.96 & 3.68 & 9.96 & 8.08 \\
\hline Moderate & 54.13 & 40.09 & 45.85 & 59.25 & 49.89 & 44.33 & 70.79 & 60.08 & 56.64 \\
\hline Good (*) & 23.82 & 42.40 & 24.81 & 32.18 & 33.24 & 36.02 & 22.65 & 19.82 & 30.33 \\
\hline Very Good & 6.93 & 9.62 & 5.22 & 3.16 & 9.03 & 14.01 & 2.35 & 5.68 & 2.28 \\
\hline \multicolumn{10}{|l|}{ Gender } \\
\hline Woman & 39.87 & 43.41 & 46.01 & 53.70 & 43.39 & 51.87 & 45.52 & 41.04 & 41.87 \\
\hline $\operatorname{Man}(*)$ & 60.13 & 56.59 & 53.99 & 46.30 & 56.61 & 48.13 & 54.48 & 58.96 & 58.13 \\
\hline \multicolumn{10}{|l|}{ Country of birth } \\
\hline Local (*) & 84.77 & 84.36 & 77.58 & 96.45 & 94.51 & 93.91 & 91.84 & 89.36 & 89.81 \\
\hline Other EU & 5.34 & 6.50 & 9.16 & 2.62 & & 1.83 & & 2.09 & 3.05 \\
\hline Other & 9.89 & 9.14 & 13.26 & 0.93 & 5.49 & 4.27 & 8.16 & 8.55 & 7.15 \\
\hline \multicolumn{10}{|l|}{ Adult Child Education Level } \\
\hline Pre-primary (ISCED 0) & 0.33 & 0.72 & 0.80 & & & & & 0.58 & \\
\hline Primary (ISCED 1) & & 3.46 & 9.80 & 0.03 & 0.41 & 0.15 & 0.43 & 13.60 & 12.05 \\
\hline Low secondary (ISCED 2) & 9.97 & 11.12 & 10.12 & 3.92 & 3.29 & 9.90 & 9.33 & 12.14 & 27.23 \\
\hline High Secondary (ISCED 3) (*) & 53.39 & 32.82 & 40.47 & 75.66 & 40.05 & 45.24 & 53.09 & 37.74 & 23.00 \\
\hline Post Secondary non-tertiary (ISCED 4) & 11.78 & 3.27 & 2.45 & 1.53 & 10.24 & & 3.73 & 6.85 & 1.26 \\
\hline Tertiary (ISCED 5 and 6) & 24.53 & 48.60 & 36.37 & 18.86 & 46.00 & 44.71 & 33.42 & 29.09 & 36.47 \\
\hline \multicolumn{10}{|l|}{ Adult Child Occupational Category } \\
\hline Managerial & 8.82 & 9.72 & 1.81 & 5.51 & 6.31 & 6.55 & 13.38 & 7.72 & 5.91 \\
\hline Professional & 14.64 & 18.19 & 17.41 & 10.89 & 18.91 & 22.62 & 14.18 & 15.15 & 13.89 \\
\hline Technical & 19.12 & 19.49 & 12.89 & 24.54 & 26.20 & 35.26 & 11.51 & 7.53 & 9.14 \\
\hline Clerical & 11.52 & 15.11 & 12.25 & 9.10 & 15.89 & 9.29 & 5.12 & 13.50 & 12.40 \\
\hline Sales & 13.56 & 10.01 & 14.27 & 13.25 & 8.78 & 3.20 & 10.50 & 14.42 & 15.26 \\
\hline Skilled Agricultural (*) & 1.93 & 0.43 & 1.65 & 1.69 & 1.01 & 2.06 & 3.73 & 10.34 & 2.64 \\
\hline Craft Trade & 12.93 & 11.12 & 14.91 & 16.14 & 8.44 & 10.97 & 16.42 & 13.40 & 13.89 \\
\hline Machine operation & 6.30 & 7.51 & 7.56 & 12.26 & 9.79 & 4.49 & 17.70 & 7.19 & 11.18 \\
\hline Elementary & 10.97 & 8.42 & 15.44 & 6.18 & 4.69 & 5.41 & 6.72 & 8.84 & 15.00 \\
\hline Armed/Military & 0.22 & & 1.81 & 0.43 & & 0.15 & 0.75 & 1.89 & 0.69 \\
\hline
\end{tabular}

Table A2.A Descriptive values of variables and shares of each category (in percentage) - 2011 


\begin{tabular}{|c|c|c|c|c|c|c|c|c|c|}
\hline & FI & FR & HU & IE & IS & IT & LT & $\overline{L U}$ & LV \\
\hline Observations & 1174 & 4061 & 5059 & 1576 & 948 & 8546 & 1791 & 2869 & 2280 \\
\hline Income Mean & 24117.49 & 20646.93 & 3868.11 & 22969.11 & 13229.31 & 16942.67 & 3627.96 & 31502.75 & 3565.00 \\
\hline Income Standard Deviation & 10775.89 & 10223.05 & 2097.67 & 12756.74 & 4899.98 & 9019.30 & 2233.40 & 17132.12 & 2463.83 \\
\hline
\end{tabular}

Father Education Level

$\begin{array}{lccccccccc} & & & & & \\ \text { No Education } & 0.85 & 3.74 & 1.96 & 1.08 & 0.11 & 2.20 & 1.17 & 4.39 & 0.18 \\ \text { Low Education (ISCED 0,1, or 2) }\left(^{*}\right) & 49.83 & 74.74 & 59.74 & 55.65 & 34.07 & 75.77 & 59.30 & 50.12 & 45.00 \\ \text { Middle Education (ISCED 3 or 4) } & 28.53 & 8.99 & 27.61 & 29.70 & 49.79 & 17.14 & 29.15 & 31.40 & 42.24 \\ \text { High Education (ISCED 5 or 6) } & 20.78 & 12.53 & 10.69 & 13.58 & 16.03 & 4.89 & 10.39 & 14.08 & 12.59\end{array}$

Mother's Education Level

\begin{tabular}{lccccccccc}
\hline No Education & 1.11 & 5.74 & 2.85 & 1.02 & 0.11 & 3.05 & 1.06 & 6.94 & 0.22 \\
Low Education (ISCED 0,1, or 2) $\left(^{*}\right)$ & 46.17 & 74.74 & 61.26 & 50.44 & 61.81 & 79.79 & 50.59 & 58.84 & 37.81 \\
Middle Education (ISCED 3 or 4) & 31.94 & 10.00 & 29.29 & 37.06 & 28.80 & 14.09 & 36.68 & 25.34 & 47.32 \\
High Education (ISCED 5 or 6) & 20.78 & 9.53 & 6.60 & 11.48 & 9.28 & 3.07 & 11.67 & 8.89 & 14.65
\end{tabular}

Father Occupational Category

\begin{tabular}{|c|c|c|c|c|c|c|c|c|c|}
\hline Managerial & 3.83 & 9.31 & 3.68 & 12.56 & 12.03 & 6.38 & 5.97 & 7.49 & 4.08 \\
\hline Professional & 12.86 & 8.42 & 7.23 & 10.28 & 13.71 & 5.39 & 8.77 & 10.18 & 10.39 \\
\hline Technical & 11.24 & 12.76 & 5.44 & 5.33 & 6.96 & 9.13 & 3.41 & 12.65 & 5.26 \\
\hline Clerical & 1.53 & 7.83 & 1.66 & 2.28 & 2.00 & 6.81 & 1.56 & 5.26 & 1.01 \\
\hline Sales & 6.56 & 4.19 & 5.14 & 8.06 & 9.39 & 7.48 & 3.07 & 3.38 & 2.28 \\
\hline Skilled Agricultural (*) & 19.59 & 9.78 & 8.08 & 13.90 & 18.78 & 9.17 & 7.76 & 10.32 & 6.62 \\
\hline Craft Trade & 16.10 & 15.81 & 30.07 & 16.56 & 21.94 & 26.01 & 26.47 & 24.75 & 26.93 \\
\hline Machine operation & 16.61 & 5.86 & 22.04 & 6.35 & 9.60 & 11.99 & 21.11 & 18.89 & 30.31 \\
\hline Elementary & 4.09 & 21.94 & 13.03 & 13.77 & 4.11 & 11.60 & 20.04 & 3.83 & 9.34 \\
\hline Armed/Military & 1.02 & 1.40 & 1.46 & 2.35 & 0.11 & 1.42 & 0.73 & 1.12 & 1.80 \\
\hline Unemployed & 6.56 & 2.71 & 2.17 & 8.57 & 1.37 & 4.62 & 1.12 & 2.13 & 1.97 \\
\hline
\end{tabular}

Perceived financial situation in childhood

\begin{tabular}{|c|c|c|c|c|c|c|c|c|c|}
\hline Very bad & 0.85 & 3.00 & 2.45 & 3.68 & 3.27 & 2.84 & 1.17 & 3.69 & 1.14 \\
\hline $\mathrm{Bad}$ & 3.83 & 6.99 & 7.14 & 7.61 & 5.70 & 6.17 & 6.48 & 7.81 & 3.46 \\
\hline Moderate & 58.09 & 59.37 & 66.08 & 54.44 & 60.97 & 67.95 & 59.24 & 49.77 & 60.00 \\
\hline Good (*) & 31.60 & 25.81 & 21.92 & 27.47 & 20.99 & 20.99 & 30.04 & 32.24 & 29.17 \\
\hline Very Good & 5.62 & 4.83 & 2.41 & 6.79 & 9.07 & 2.05 & 3.07 & 6.48 & 6.23 \\
\hline \multicolumn{10}{|l|}{ Gender } \\
\hline Woman & 45.57 & 43.98 & 45.42 & 57.23 & 52.64 & 40.62 & 54.16 & 38.90 & 53.86 \\
\hline $\operatorname{Man}(*)$ & 54.43 & 56.02 & 54.58 & 42.77 & 47.36 & 59.38 & 45.84 & 61.10 & 46.14 \\
\hline \multicolumn{10}{|c|}{ Country of birth } \\
\hline Local $(*)$ & 94.04 & 90.47 & 98.99 & 78.93 & 89.45 & 90.84 & 95.25 & 46.43 & 90.83 \\
\hline Other EU & 2.81 & 2.86 & 0.75 & 14.78 & 6.43 & 3.07 & 0.50 & 43.26 & \\
\hline Other & 3.15 & 6.67 & 0.26 & 6.28 & 4.11 & 6.10 & 4.24 & 10.32 & 9.17 \\
\hline
\end{tabular}

Adult Child Education Level

\begin{tabular}{|c|c|c|c|c|c|c|c|c|c|}
\hline Pre-primary (ISCED 0) & & 0.34 & & & & 0.25 & 0.06 & & 0.04 \\
\hline Primary (ISCED 1) & & 5.20 & 1.64 & 5.71 & 0.21 & 2.80 & 0.67 & 23.18 & 0.31 \\
\hline Low secondary (ISCED 2) & 6.30 & 8.18 & 13.22 & 13.96 & 18.14 & 31.06 & 5.75 & 10.07 & 12.19 \\
\hline High Secondary (ISCED 3 ) (*) & 43.02 & 47.11 & 56.63 & 21.32 & 32.38 & 43.27 & 32.27 & 33.11 & 48.68 \\
\hline Post Secondary non-tertiary (ISCED 4) & 1.28 & 0.42 & 4.53 & 8.76 & 10.34 & 3.71 & 27.19 & 2.02 & 7.15 \\
\hline Tertiary (ISCED 5 and 6) & 49.40 & 38.76 & 23.98 & 50.25 & 38.92 & 18.92 & 34.06 & 31.61 & 31.62 \\
\hline \multicolumn{10}{|l|}{ Adult Child Occupational Category } \\
\hline Managerial & 10.48 & 8.52 & 4.57 & 8.25 & 11.71 & 8.51 & 9.83 & 6.45 & 8.51 \\
\hline Professional & 21.12 & 15.74 & 15.04 & 19.29 & 30.17 & 12.46 & 19.21 & 19.10 & 18.99 \\
\hline Technical & 16.01 & 19.50 & 11.80 & 12.69 & 12.13 & 16.62 & 9.32 & 19.21 & 12.46 \\
\hline Clerical & 4.94 & 10.79 & 7.47 & 13.26 & 6.43 & 14.15 & 4.80 & 10.81 & 6.14 \\
\hline Sales & 16.87 & 10.32 & 11.33 & 12.25 & 17.19 & 10.81 & 11.95 & 9.79 & 12.54 \\
\hline Skilled Agricultural (*) & 8.94 & 3.13 & 2.63 & 7.93 & 5.17 & 1.95 & 4.91 & 2.89 & 2.63 \\
\hline Craft Trade & 10.39 & 10.88 & 18.13 & 8.12 & 8.33 & 15.45 & 16.47 & 13.07 & 13.73 \\
\hline Machine operation & 7.33 & 9.63 & 13.72 & 7.49 & 2.64 & 8.54 & 12.34 & 6.76 & 10.66 \\
\hline Elementary & 3.49 & 10.22 & 14.09 & 10.72 & 6.22 & 10.20 & 10.94 & 11.85 & 14.21 \\
\hline Armed/Military & 0.43 & 1.28 & 1.23 & & & 1.31 & 0.22 & 0.07 & 0.13 \\
\hline
\end{tabular}

Table A2.B Descriptive values of variables and shares of each category (in percentage) - 2011 (cont.) 


\begin{tabular}{|c|c|c|c|c|c|c|c|c|}
\hline & $\mathrm{NL}$ & $\mathrm{NO}$ & $\overline{\mathrm{PL}}$ & $\mathrm{PT}$ & $\mathrm{SE}$ & SI & SK & UK \\
\hline ations & 2980 & 1574 & 5288 & 2229 & 1280 & 2758 & 2546 & 2565 \\
\hline Income Mean & 23565.42 & 36954.13 & 4854.86 & 9320.42 & 22766.68 & 11709.01 & 6225.33 & 19194.33 \\
\hline Income Standard Deviation & 9717.66 & 13440.66 & 2886.16 & 5910.61 & 8205.95 & 4786.54 & 2661.38 & 11564.46 \\
\hline
\end{tabular}

Father Education Level

\begin{tabular}{|c|c|c|c|c|c|c|c|c|}
\hline No Education & 0.34 & 0.38 & 0.28 & 18.21 & & 0.11 & 0.04 & 2.53 \\
\hline Low Education (ISCED 0,1 , or 2 ) $\left(^{*}\right)$ & 39.60 & 26.37 & 43.44 & 75.41 & 39.69 & 69.00 & 31.46 & 52.32 \\
\hline Middle Education (ISCED 3 or 4 ) & 35.03 & 39.83 & 49.30 & 2.87 & 39.77 & 19.98 & 58.72 & 27.10 \\
\hline High Education (ISCED 5 or 6 ) & 25.03 & 33.42 & 6.98 & 3.50 & 20.55 & 10.91 & 9.78 & 18.05 \\
\hline
\end{tabular}

Mother's Education Level

\begin{tabular}{lcccccccc}
\hline No Education & 0.37 & 0.95 & 0.28 & 25.39 & & 0.18 & 0.04 & 3.24 \\
Low Education (ISCED 0,1, or 2) $(*)$ & 51.21 & 28.08 & 48.07 & 68.60 & 34.30 & 73.24 & 38.88 & 68.85 \\
Middle Education (ISCED 3 or 4) & 36.98 & 47.52 & 45.73 & 2.38 & 39.69 & 18.75 & 55.89 & 12.20 \\
High Education (ISCED 5 or 6) & 11.44 & 23.44 & 5.92 & 3.63 & 26.02 & 7.83 & 5.18 & 15.71
\end{tabular}

Father Occupational Category

\begin{tabular}{|c|c|c|c|c|c|c|c|c|}
\hline Managerial & 10.67 & 12.77 & 3.97 & 5.29 & 1.02 & 2.90 & 4.87 & 10.88 \\
\hline Professional & 15.77 & 13.47 & 4.61 & 3.59 & 3.98 & 7.29 & 7.46 & 16.34 \\
\hline Technical & 17.85 & 18.93 & 5.88 & 6.10 & 1.80 & 12.11 & 10.64 & 9.20 \\
\hline Clerical & 5.50 & 3.18 & 2.31 & 3.95 & 0.70 & 4.31 & 3.06 & 3.63 \\
\hline Sales & 6.88 & 5.46 & 4.27 & 10.09 & 2.34 & 5.69 & 4.05 & 7.21 \\
\hline Skilled Agricultural (*) & 8.09 & 9.02 & 23.52 & 19.43 & 1.88 & 7.32 & 2.16 & 3.00 \\
\hline Craft Trade & 20.47 & 21.73 & 26.76 & 27.82 & 6.25 & 27.92 & 33.62 & 23.39 \\
\hline Machine operation & 6.64 & 9.40 & 18.06 & 12.52 & 3.20 & 9.86 & 22.90 & 12.71 \\
\hline Elementary & 2.65 & 2.54 & 7.68 & 8.39 & 0.47 & 17.40 & 9.15 & 6.98 \\
\hline Armed/Military & 1.71 & 2.03 & 1.02 & & 0.23 & 0.40 & 0.90 & 1.48 \\
\hline Unemployed & 3.76 & 1.46 & 1.91 & 2.83 & 1.17 & 4.79 & 1.18 & 5.19 \\
\hline \multicolumn{9}{|c|}{ Perceived financiancial situation in childhood } \\
\hline Very bad & 0.81 & 0.76 & 1.55 & 9.11 & 2.27 & 5.33 & 1.45 & 3.12 \\
\hline Bad & 2.95 & 3.05 & 6.86 & 15.16 & 5.16 & 10.88 & 4.60 & 5.65 \\
\hline Moderate & 36.48 & 44.03 & 56.30 & 60.30 & 37.42 & 65.95 & 56.60 & 55.95 \\
\hline Good (*) & 50.07 & 44.22 & 32.15 & 14.36 & 42.34 & 13.56 & 32.52 & 28.50 \\
\hline Very good & 9.70 & 7.94 & 3.14 & 1.08 & 12.81 & 4.28 & 4.83 & 6.78 \\
\hline \multicolumn{9}{|l|}{ Gender } \\
\hline Woman & 52.48 & 46.12 & 46.41 & 46.43 & 51.33 & 53.44 & 46.86 & 49.51 \\
\hline $\operatorname{Man}(*)$ & 47.52 & 53.88 & 53.59 & 53.57 & 48.67 & 46.56 & 53.14 & 50.49 \\
\hline \multicolumn{9}{|l|}{ Country of birth } \\
\hline Local $\left(^{*}\right)$ & 94.90 & 92.38 & 99.91 & 91.34 & 94.30 & 89.45 & 98.94 & 88.15 \\
\hline Other EU & 1.44 & 3.49 & 0.02 & 2.33 & 2.34 & & 0.94 & 3.16 \\
\hline Other & 3.66 & 4.13 & 0.08 & 6.33 & 3.36 & 10.55 & 0.12 & 8.69 \\
\hline \multicolumn{9}{|l|}{ Adult Child Education Level } \\
\hline Pre-primary (ISCED 0) & 0.17 & 0.06 & 0.09 & & & & & \\
\hline Primary (ISCED 1) & 0.91 & 0.13 & 7.32 & 42.17 & & 0.98 & & \\
\hline Low secondary (ISCED 2) & 10.20 & 10.42 & & 21.98 & 3.59 & 10.77 & 2.83 & 7.33 \\
\hline High Secondary (ISCED 3) $\left(^{*}\right)$ & 40.20 & 36.91 & 64.58 & 18.71 & 43.05 & 57.40 & 69.76 & 46.51 \\
\hline Post Secondary non-tertiary (ISCED 4) & 3.26 & 3.75 & 4.61 & 0.36 & 8.28 & & 2.24 & 0.16 \\
\hline Tertiary (ISCED 5 and 6) & 45.27 & 48.73 & 23.39 & 16.78 & 45.08 & 30.86 & 25.18 & 46.00 \\
\hline \multicolumn{9}{|l|}{ Adult Child Occupational Category } \\
\hline Managerial & 11.71 & 10.67 & 5.77 & 5.16 & 6.88 & 4.86 & 6.36 & 19.42 \\
\hline Professional & 27.89 & 18.93 & 15.20 & 10.54 & 26.33 & 18.89 & 12.18 & 15.98 \\
\hline Technical & 24.03 & 30.94 & 11.04 & 10.36 & 25.16 & 19.83 & 23.02 & 15.05 \\
\hline Clerical & 11.74 & 6.29 & 5.64 & 9.02 & 5.16 & 9.43 & 8.44 & 10.99 \\
\hline Sales & 9.66 & 14.99 & 11.59 & 16.20 & 15.47 & 12.87 & 13.75 & 14.74 \\
\hline Skilled Agricultural (*) & 0.94 & 1.97 & 10.61 & 4.76 & 1.48 & 1.63 & 0.82 & 0.78 \\
\hline Craft Trade & 6.41 & 9.21 & 18.87 & 19.11 & 8.91 & 10.91 & 16.38 & 7.41 \\
\hline Machine operation & 4.03 & 4.89 & 11.63 & 10.23 & 8.05 & 11.97 & 12.88 & 5.69 \\
\hline Elementary & 3.36 & 2.03 & 9.02 & 14.40 & 2.03 & 8.56 & 5.50 & 9.94 \\
\hline Armed/Military & 0.23 & 0.06 & 0.62 & 0.22 & 0.55 & 1.05 & 0.67 & \\
\hline
\end{tabular}

Table A2.C Descriptive values of variables and shares of each category (in percentage) - 2011 (cont.) 
Table A3: Regression coefficients of circumstances on income. The omitted categories are Low Level Education, Skilled Agricultural occupation, Difficulties Rarely, Local Citizen and Man.

\begin{tabular}{|c|c|c|c|c|c|c|c|c|c|c|c|c|}
\hline & \multicolumn{2}{|c|}{ AT } & \multicolumn{2}{|c|}{$\mathrm{BE}$} & \multicolumn{2}{|c|}{$\mathrm{CY}$} & \multicolumn{2}{|c|}{$\mathrm{CZ}$} & \multicolumn{2}{|c|}{$\mathrm{DE}$} & \multicolumn{2}{|c|}{ DK } \\
\hline & 2004 & 2010 & 2004 & 2010 & 2004 & 2010 & 2004 & 2010 & 2004 & 2010 & 2004 & 2010 \\
\hline Constant & $\begin{array}{l}9.783^{* * *} \\
(0.038)\end{array}$ & $\begin{array}{l}9.862^{* * *} \\
(0.031)\end{array}$ & $\begin{array}{l}9.748^{* * *} \\
(0.054)\end{array}$ & $\begin{array}{l}9.795^{* * *} \\
(0.046)\end{array}$ & $\begin{array}{l}9.589^{* * *} \\
(0.033)\end{array}$ & $\begin{array}{l}9.670^{* * *} \\
(0.040)\end{array}$ & $\begin{array}{l}8.303^{* * *} \\
(0.054)\end{array}$ & $\begin{array}{l}8.787^{* * *} \\
(0.046)\end{array}$ & $\begin{array}{l}9.737^{* * *} \\
(0.032)\end{array}$ & $\begin{array}{l}9.831^{* * *} \\
(0.050)\end{array}$ & $\begin{array}{l}10.035^{* * *} \\
(0.030)\end{array}$ & $\begin{array}{l}10.057^{* * *} \\
(0.037)\end{array}$ \\
\hline \multirow{2}{*}{ No Education (F) } & & -0.016 & -0.023 & 0.026 & -0.031 & -0.017 & & 0.154 & & -0.022 & & \\
\hline & & $(0.119)$ & $(0.047)$ & $(0.102)$ & $(0.029)$ & $(0.063)$ & & $(0.211)$ & & $(0.177)$ & & \\
\hline \multirow[t]{2}{*}{ Medium Level Education (F) } & 0.004 & -0.025 & 0.013 & $0.045^{*}$ & $0.108^{* * *}$ & 0.017 & $0.126^{* * *}$ & $0.091^{* * *}$ & $0.044^{* *}$ & $0.059^{*}$ & -0.021 & 0.030 \\
\hline & $(0.040)$ & $(0.023)$ & $(0.027)$ & $(0.027)$ & $(0.036)$ & $(0.035)$ & $(0.037)$ & $(0.026)$ & $(0.022)$ & $(0.033)$ & $(0.024)$ & $(0.027)$ \\
\hline \multirow[t]{2}{*}{ High Level Education (F) } & $0.306^{* *}$ & 0.055 & 0.007 & $0.140^{* * *}$ & $0.147^{* *}$ & 0.026 & $0.190^{* * *}$ & $0.087^{* *}$ & -0.001 & $0.130^{* * *}$ & -0.018 & -0.007 \\
\hline & $(0.156)$ & $(0.034)$ & $(0.040)$ & $(0.039)$ & $(0.065)$ & $(0.058)$ & $(0.065)$ & $(0.044)$ & $(0.026)$ & $(0.037)$ & $(0.038)$ & $(0.040)$ \\
\hline No Education (M) & & $\begin{array}{r}0.000 \\
(0.073)\end{array}$ & $\begin{array}{r}-0.053 \\
(0.046)\end{array}$ & $\begin{array}{r}-0.121 \\
(0.082)\end{array}$ & $-0.051^{*}$ & $-0.165^{* * *}$ & & $-0.648^{* * *}$ & & $\begin{array}{r}-0.040 \\
(0.107)\end{array}$ & & \\
\hline \multirow{2}{*}{ Medium Level Education (M) } & $0.125^{* * *}$ & $0.087^{* * *}$ & $\begin{array}{r}0.040) \\
0.032\end{array}$ & $0.084^{* * *}$ & $0.108^{* * *}$ & $0.067 *$ & $0.053^{* *}$ & $0.104^{* * *}$ & 0.018 & 0.033 & 0.019 & $0.084^{* * *}$ \\
\hline & $(0.032)$ & $(0.021)$ & $(0.028)$ & $(0.026)$ & $(0.038)$ & $(0.035)$ & $(0.027)$ & $(0.020)$ & $(0.015)$ & $(0.022)$ & $(0.020)$ & $(0.026)$ \\
\hline \multirow[t]{2}{*}{ High Level Education (M) } & 0.101 & $0.144^{* * *}$ & $0.067^{*}$ & $0.095^{* * *}$ & $0.186^{* * *}$ & $0.137^{* *}$ & 0.083 & $0.258^{* * *}$ & -0.002 & 0.038 & 0.037 & -0.009 \\
\hline & $(0.075)$ & $(0.047)$ & $(0.039)$ & $(0.034)$ & $(0.063)$ & $(0.058)$ & $(0.064)$ & $(0.043)$ & $(0.024)$ & $(0.032)$ & $(0.029)$ & $(0.032)$ \\
\hline \multirow[t]{2}{*}{ Managerial (F) } & 0.018 & $0.142^{* * *}$ & 0.087 & 0.048 & 0.080 & $0.523^{* * *}$ & 0.046 & 0.063 & $0.116^{* * *}$ & 0.017 & 0.062 & $0.163^{* * *}$ \\
\hline & $(0.079)$ & $(0.049)$ & $(0.058)$ & $(0.060)$ & $(0.112)$ & $(0.101)$ & $(0.074)$ & $(0.065)$ & $(0.039)$ & $(0.055)$ & $(0.041)$ & $(0.045)$ \\
\hline \multirow[t]{2}{*}{ Professional (F) } & $-0.312^{*}$ & 0.059 & 0.064 & 0.077 & $0.134^{*}$ & $0.328^{* * *}$ & 0.038 & 0.094 & $0.088^{* *}$ & -0.025 & 0.060 & $0.231^{* * *}$ \\
\hline & $(0.173)$ & $(0.052)$ & $(0.061)$ & $(0.058)$ & $(0.069)$ & $(0.067)$ & $(0.075)$ & $(0.060)$ & $(0.035)$ & $(0.049)$ & $(0.047)$ & $(0.050)$ \\
\hline Technical (F) & $\begin{array}{c}0.126^{* *} \\
(0.061)\end{array}$ & $\begin{array}{l}0.130^{* * *} \\
(0.042)\end{array}$ & $\begin{array}{r}0.021 \\
(0.062)\end{array}$ & $\begin{array}{l}0.134^{* *} \\
(0.055)\end{array}$ & $\begin{array}{l}0.143^{* * *} \\
(0.055)\end{array}$ & $\begin{array}{l}0.180^{* * * *} \\
(0.053)\end{array}$ & $\begin{array}{r}0.039 \\
(0.056)\end{array}$ & $\begin{array}{r}0.048 \\
(0.051)\end{array}$ & $\begin{array}{c}0.066^{*} \\
(0.035)\end{array}$ & $\begin{array}{l}-0.050 \\
(0.046)\end{array}$ & $\begin{array}{c}0.076^{*} \\
(0.040)\end{array}$ & $\begin{array}{l}0.173^{* * *} \\
(0.050)\end{array}$ \\
\hline \multirow[t]{2}{*}{ Clerical (F) } & 0.098 & $0.164^{* * *}$ & $0.111^{*}$ & $0.139^{* *}$ & $0.216^{* * *}$ & $0.150^{* *}$ & $0.209^{* *}$ & 0.024 & $0.066^{*}$ & 0.025 & 0.069 & $0.286^{* * *}$ \\
\hline & $(0.073)$ & $(0.044)$ & $(0.057)$ & $(0.056)$ & $(0.058)$ & $(0.068)$ & $(0.082)$ & $(0.063)$ & $(0.037)$ & $(0.054)$ & $(0.045)$ & $(0.061)$ \\
\hline \multirow[t]{2}{*}{ Sales (F) } & -0.015 & $0.084^{* *}$ & 0.039 & 0.011 & 0.022 & $0.153^{* * *}$ & -0.077 & -0.039 & $0.107^{* *}$ & -0.028 & 0.037 & $0.088^{* *}$ \\
\hline & $(0.053)$ & $(0.034)$ & $(0.063)$ & $(0.061)$ & $(0.039)$ & $(0.048)$ & $(0.074)$ & $(0.061)$ & $(0.048)$ & $(0.053)$ & $(0.045)$ & $(0.045)$ \\
\hline \multirow[t]{2}{*}{ Craft Trade (F) } & -0.017 & 0.021 & -0.016 & $0.086^{*}$ & $0.077^{* *}$ & $0.064^{*}$ & -0.050 & 0.005 & 0.015 & $-0.117^{* * *}$ & 0.019 & $0.080^{* *}$ \\
\hline & $(0.046)$ & $(0.030)$ & $(0.050)$ & $(0.049)$ & $(0.032)$ & $(0.038)$ & $(0.050)$ & $(0.045)$ & $(0.031)$ & $(0.044)$ & $(0.034)$ & $(0.035)$ \\
\hline \multirow[t]{2}{*}{ Machine opperation (F) } & -0.009 & 0.015 & -0.001 & 0.023 & 0.015 & $0.078^{*}$ & -0.084 & -0.052 & 0.011 & $-0.135^{* * *}$ & -0.049 & 0.047 \\
\hline & $(0.059)$ & $(0.041)$ & $(0.057)$ & $(0.052)$ & $(0.039)$ & $(0.044)$ & $(0.052)$ & $(0.046)$ & $(0.034)$ & $(0.047)$ & $(0.037)$ & $(0.051)$ \\
\hline Elementary Occ. (F) & -0.064 & -0.035 & -0.004 & 0.050 & 0.019 & -0.061 & $-0.229^{* * *}$ & $-0.113^{* *}$ & $0.086^{* *}$ & -0.054 & -0.024 & $0.412^{* * *}$ \\
\hline & $(0.049)$ & $(0.039)$ & $(0.055)$ & $(0.063)$ & $(0.033)$ & $(0.042)$ & $(0.063)$ & $(0.057)$ & $(0.040)$ & $(0.062)$ & $(0.033)$ & $(0.135)$ \\
\hline Armed/Military (F) & 0.285 & -0.044 & 0.086 & -0.001 & -0.079 & 0.035 & 0.003 & -0.039 & $0.149^{* *}$ & & 0.103 & \\
\hline & $(0.641)$ & $(0.086)$ & $(0.080)$ & $(0.064)$ & $(0.157)$ & $(0.157)$ & $(0.111)$ & $(0.083)$ & $(0.068)$ & & $(0.092)$ & \\
\hline Unemployed (F) & $-0.399^{*}$ & -0.037 & -0.056 & & 0.031 & 0.099 & -0.195 & 0.070 & -0.050 & -0.073 & $-0.149^{* *}$ & -0.034 \\
\hline & $(0.227)$ & $(0.062)$ & $(0.056)$ & & $(0.142)$ & $(0.085)$ & $(0.220)$ & $(0.088)$ & $(0.046)$ & $(0.072)$ & $(0.058)$ & $(0.076)$ \\
\hline Difficulties most of the time & & -0.059 & $-0.155^{* * *}$ & $-0.128^{*}$ & $-0.236^{* * *}$ & $-0.151^{* * *}$ & $-0.103^{*}$ & -0.013 & & $\begin{array}{l}-0.089 \\
(0.058)\end{array}$ & $-0.113^{* *}$ & -0.043 \\
\hline Difficulties often & & $\begin{array}{r}(0.040) \\
-0.046\end{array}$ & $\begin{array}{l}(0.057) \\
-0.051\end{array}$ & $-0.190^{* * *}$ & $\begin{array}{l}(0.047) \\
-0.188^{* * *}\end{array}$ & $\begin{array}{l}(0.042) \\
-0.160^{* * *}\end{array}$ & $\begin{array}{r}(0.057) \\
-0.030\end{array}$ & $\begin{array}{l}(0.074) \\
-0.155^{* * *}\end{array}$ & & $\begin{array}{r}(0.058) \\
-0.020\end{array}$ & $\begin{array}{l}(0.051) \\
-0.079 *\end{array}$ & $\begin{array}{l}(0.091) \\
-0.130^{* *}\end{array}$ \\
\hline & & $(0.033)$ & $(0.048)$ & $(0.046)$ & $(0.031)$ & $(0.040)$ & $(0.043)$ & $(0.044)$ & & $(0.039)$ & $(0.044)$ & $(0.054)$ \\
\hline Difficulties occasionally & & 0.030 & 0.002 & $-0.051^{* *}$ & $-0.058^{* *}$ & -0.041 & 0.010 & -0.002 & & $0.046^{* *}$ & 0.005 & -0.029 \\
\hline & & $(0.022)$ & $(0.038)$ & $(0.022)$ & $(0.024)$ & $(0.028)$ & $(0.031)$ & $(0.018)$ & & $(0.019)$ & $(0.029)$ & $(0.024)$ \\
\hline Difficulties never & & 0.007 & $0.074^{* *}$ & -0.053 & 0.061 & -0.048 & $0.057^{*}$ & -0.014 & & $-0.064^{* *}$ & 0.002 & -0.043 \\
\hline & & $(0.037)$ & $(0.030)$ & $(0.036)$ & $(0.041)$ & $(0.050)$ & $(0.030)$ & $(0.048)$ & & $(0.031)$ & $(0.022)$ & $(0.033)$ \\
\hline Other European Union & 0.061 & $-0.219^{* * *}$ & 0.040 & 0.007 & $-0.085^{*}$ & $-0.191 * * *$ & 0.105 & -0.022 & & & 0.103 & $-0.177^{* *}$ \\
\hline & $(0.078)$ & $(0.036)$ & $(0.045)$ & $(0.040)$ & $(0.045)$ & $(0.037)$ & $(0.080)$ & $(0.052)$ & & & $(0.100)$ & $(0.075)$ \\
\hline Other outside EU & $\begin{array}{l}-0.280^{* * *} \\
(0.041)\end{array}$ & $\begin{array}{l}-0.338^{* * *} \\
(0.028)\end{array}$ & $\begin{array}{l}-0.334^{* * *} \\
(0.048)\end{array}$ & $\begin{array}{l}-0.518^{* * *} \\
(0.037)\end{array}$ & $\begin{array}{l}-0.410^{* * *} \\
(0.034)\end{array}$ & $\begin{array}{l}-0.461^{* * *} \\
(0.037)\end{array}$ & $\begin{array}{l}-0.319^{* * * *} \\
(0.096)\end{array}$ & $\begin{array}{l}-0.001 \\
(0.075)\end{array}$ & $\begin{array}{l}-0.140^{* * *} \\
(0.031)\end{array}$ & $\begin{array}{l}-0.174^{* * *} \\
(0.038)\end{array}$ & $\begin{array}{l}-0.165^{* * *} \\
(0.058)\end{array}$ & $\begin{array}{l}-0.150^{* * *} \\
(0.052)\end{array}$ \\
\hline Woman & -0.007 & -0.026 & $-0.063^{* * *}$ & $-0.060^{* * *}$ & -0.022 & 0.014 & $-0.096^{* * *}$ & $-0.062^{* * *}$ & $-0.090^{* * *}$ & $-0.107 * * *$ & -0.004 & $-0.055^{* * *}$ \\
\hline & $(0.026)$ & $(0.018)$ & $(0.020)$ & $(0.020)$ & $(0.021)$ & $(0.023)$ & $(0.023)$ & $(0.017)$ & $(0.013)$ & $(0.017)$ & $(0.017)$ & $(0.021)$ \\
\hline R-Squared & 0.065 & 0.125 & 0.093 & 0.180 & 0.194 & 0.200 & 0.100 & 0.095 & 0.024 & 0.039 & 0.035 & 0.083 \\
\hline
\end{tabular}




\begin{tabular}{|c|c|c|c|c|c|c|c|c|c|c|c|c|}
\hline & \multicolumn{2}{|c|}{$\mathrm{EE}$} & \multicolumn{2}{|c|}{ EL } & \multicolumn{2}{|c|}{ ES } & \multicolumn{2}{|c|}{ FI } & \multicolumn{2}{|c|}{ FR } & \multicolumn{2}{|c|}{ HU } \\
\hline & 2004 & 2010 & 2004 & 2010 & 2004 & 2010 & 2004 & 2010 & 2004 & 2010 & 2004 & 2010 \\
\hline Constant & $\begin{array}{l}7.771 * * * \\
(0.105)\end{array}$ & $\begin{array}{l}8.279 * * * \\
(0.090)\end{array}$ & $\begin{array}{l}9.146^{* * *} \\
(0.027)\end{array}$ & $\begin{array}{l}9.072^{* * *} \\
(0.044)\end{array}$ & $\begin{array}{l}9.220 * * * \\
(0.029)\end{array}$ & $\begin{array}{l}9.224^{* * *} \\
(0.033)\end{array}$ & $\begin{array}{l}9.784^{* * *} \\
(0.024)\end{array}$ & $\begin{array}{l}9.891 * * * \\
(0.043)\end{array}$ & $\begin{array}{l}9.660^{* * *} \\
(0.021)\end{array}$ & $\begin{array}{l}9.778^{* * *} \\
(0.028)\end{array}$ & $\begin{array}{l}7.958^{* * *} \\
(0.031)\end{array}$ & $\begin{array}{l}7.984^{* * *} \\
(0.028)\end{array}$ \\
\hline \multirow[t]{2}{*}{ No Education (F) } & -0.189 & & $-0.118^{* * *}$ & 0.109 & $-0.087^{* * *}$ & $-0.111^{*}$ & -0.251 & -0.026 & $-0.075^{* *}$ & $-0.098^{* *}$ & 0.004 & -0.046 \\
\hline & $(0.174)$ & & $(0.038)$ & $(0.093)$ & $(0.027)$ & $(0.060)$ & $(0.237)$ & $(0.166)$ & $(0.037)$ & $(0.045)$ & $(0.103)$ & $(0.053)$ \\
\hline Medium Level Education (F) & $\begin{array}{l}0.084^{* *} \\
(0.038)\end{array}$ & $\begin{array}{r}0.047 \\
(0.040)\end{array}$ & $\begin{array}{l}0.112^{* *} \\
(0.051)\end{array}$ & $\begin{array}{l}0.151^{* * *} \\
(0.044)\end{array}$ & $\begin{array}{c}0.069^{*} \\
(0.038)\end{array}$ & $\begin{array}{l}0.084^{* *} \\
(0.039)\end{array}$ & $\begin{array}{r}0.009 \\
(0.021)\end{array}$ & $\begin{array}{r}0.038 \\
(0.033)\end{array}$ & $\begin{array}{l}0.057^{* * *} \\
(0.018)\end{array}$ & $\begin{array}{c}0.049^{*} \\
(0.027)\end{array}$ & $\begin{array}{l}0.108^{* * *} \\
(0.024)\end{array}$ & $\begin{array}{r}0.027 \\
(0.018)\end{array}$ \\
\hline High Level Education (F) & $\begin{array}{l}0.145^{* *} \\
(0.064)\end{array}$ & $\begin{array}{r}0.067 \\
(0.060)\end{array}$ & $\begin{array}{r}0.116 \\
(0.079)\end{array}$ & $\begin{array}{c}0.128^{*} \\
(0.065)\end{array}$ & $\begin{array}{l}0.149^{* * *} \\
(0.039)\end{array}$ & $\begin{array}{l}0.134^{* * *} \\
(0.045)\end{array}$ & $\begin{array}{l}0.080^{* * *} \\
(0.030)\end{array}$ & $\begin{array}{r}0.005 \\
(0.046)\end{array}$ & $\begin{array}{l}0.076^{* *} \\
(0.035)\end{array}$ & $\begin{array}{l}0.115^{* * *} \\
(0.030)\end{array}$ & $\begin{array}{l}0.171^{* * *} \\
(0.055)\end{array}$ & $\begin{array}{l}0.178^{* * *} \\
(0.037)\end{array}$ \\
\hline No Education (M) & $\begin{array}{r}0.018 \\
(0.141)\end{array}$ & $\begin{array}{l}-1.421 \\
(1.270)\end{array}$ & $\begin{array}{r}-0.054 \\
(0.035)\end{array}$ & $\begin{array}{l}-0.170^{* *} \\
(0.077)\end{array}$ & $\begin{array}{l}-0.147^{* * *} \\
(0.026)\end{array}$ & $\begin{array}{l}-0.109^{* *} \\
(0.050)\end{array}$ & $\begin{array}{l}-0.433^{*} \\
(0.227)\end{array}$ & $\begin{array}{r}0.020 \\
(0.138)\end{array}$ & $\begin{array}{l}-0.108^{* * *} \\
(0.037)\end{array}$ & $\begin{array}{r}-0.056 \\
(0.039)\end{array}$ & $\begin{array}{l}-0.526^{* * *} \\
(0.086)\end{array}$ & $\begin{array}{l}-0.134^{* * *} \\
(0.045)\end{array}$ \\
\hline Medium Level Education (M) & $\begin{array}{l}0.113^{* * *} \\
(0.037)\end{array}$ & $\begin{array}{l}0.124^{* * *} \\
(0.040)\end{array}$ & $\begin{array}{l}0.142^{* * *} \\
(0.054)\end{array}$ & $\begin{array}{l}0.130^{* * *} \\
(0.046)\end{array}$ & $\begin{array}{l}0.118^{* * *} \\
(0.041)\end{array}$ & $\begin{array}{c}0.080^{*} \\
(0.044)\end{array}$ & $\begin{array}{c}0.037^{*} \\
(0.020)\end{array}$ & $\begin{array}{r}0.016 \\
(0.031)\end{array}$ & $\begin{array}{l}0.085^{* * *} \\
(0.021)\end{array}$ & $\begin{array}{l}0.055^{* *} \\
(0.026)\end{array}$ & $\begin{array}{l}0.070^{* * *} \\
(0.023)\end{array}$ & $\begin{array}{l}0.159^{* * *} \\
(0.017)\end{array}$ \\
\hline High Level Education (M) & $\begin{array}{l}0.211 * * * \\
(0.050)\end{array}$ & $\begin{array}{l}0.241^{* * *} \\
(0.051)\end{array}$ & $\begin{array}{l}0.307^{* * *} \\
(0.082)\end{array}$ & $\begin{array}{l}0.212^{* * *} \\
(0.072)\end{array}$ & $\begin{array}{l}0.118^{* * *} \\
(0.045)\end{array}$ & $\begin{array}{l}0.207^{* * *} \\
(0.048)\end{array}$ & $\begin{array}{l}0.105^{* * *} \\
(0.027)\end{array}$ & $\begin{array}{r}0.029 \\
(0.040)\end{array}$ & $\begin{array}{r}0.046 \\
(0.035)\end{array}$ & $\begin{array}{r}0.003 \\
(0.029)\end{array}$ & $\begin{array}{l}0.216^{* * *} \\
(0.050)\end{array}$ & $\begin{array}{l}0.229^{* * *} \\
(0.032)\end{array}$ \\
\hline Managerial (F) & $\begin{array}{l}0.330^{* * *} \\
(0.113)\end{array}$ & $\begin{array}{l}0.265^{* * *} \\
(0.099)\end{array}$ & $\begin{array}{l}0.232^{* * *} \\
(0.043)\end{array}$ & $\begin{array}{l}0.161^{* * *} \\
(0.058)\end{array}$ & $\begin{array}{l}0.177^{* * *} \\
(0.042)\end{array}$ & $\begin{array}{c}0.084^{*} \\
(0.048)\end{array}$ & $\begin{array}{c}0.070^{*} \\
(0.036)\end{array}$ & $\begin{array}{r}0.090 \\
(0.069)\end{array}$ & $\begin{array}{l}0.177^{* * *} \\
(0.033)\end{array}$ & $\begin{array}{l}0.162^{* * *} \\
(0.034)\end{array}$ & $\begin{array}{l}0.235^{* * *} \\
(0.053)\end{array}$ & $\begin{array}{l}0.262^{* * *} \\
(0.045)\end{array}$ \\
\hline Professional (F) & $\begin{array}{l}0.296^{* *} \\
(0.118)\end{array}$ & $\begin{array}{l}0.244^{* *} \\
(0.098)\end{array}$ & $\begin{array}{r}-0.013 \\
(0.084)\end{array}$ & $\begin{array}{l}0.328^{* * *} \\
(0.078)\end{array}$ & $\begin{array}{l}0.202^{* * *} \\
(0.057)\end{array}$ & $\begin{array}{l}0.303^{* * *} \\
(0.060)\end{array}$ & $\begin{array}{l}0.153^{* * *} \\
(0.042)\end{array}$ & $\begin{array}{r}0.067 \\
(0.058)\end{array}$ & $\begin{array}{l}0.166^{* * *} \\
(0.037)\end{array}$ & $\begin{array}{l}0.149^{* * *} \\
(0.041)\end{array}$ & $\begin{array}{c}0.123^{*} \\
(0.065)\end{array}$ & $\begin{array}{l}0.255^{* * *} \\
(0.045)\end{array}$ \\
\hline Technical (F) & $\begin{array}{l}0.342^{* * *} \\
(0.121)\end{array}$ & $\begin{array}{r}0.126 \\
(0.099)\end{array}$ & $\begin{array}{l}0.326^{* * *} \\
(0.080)\end{array}$ & $\begin{array}{r}0.082 \\
(0.081)\end{array}$ & $\begin{array}{l}0.319^{* * *} \\
(0.044)\end{array}$ & $\begin{array}{l}0.212^{* * *} \\
(0.042)\end{array}$ & $\begin{array}{l}0.069^{* *} \\
(0.031)\end{array}$ & $\begin{array}{l}0.113^{* *} \\
(0.055)\end{array}$ & $\begin{array}{l}0.161^{* * *} \\
(0.033)\end{array}$ & $\begin{array}{l}0.140^{* * *} \\
(0.032)\end{array}$ & $\begin{array}{l}0.228^{* * *} \\
(0.049)\end{array}$ & $\begin{array}{l}0.219^{* * *} \\
(0.038)\end{array}$ \\
\hline Clerical (F) & $\begin{array}{c}0.340^{*} \\
(0.174)\end{array}$ & $\begin{array}{r}0.137 \\
(0.140)\end{array}$ & $\begin{array}{l}0.241 * * * \\
(0.057)\end{array}$ & $\begin{array}{l}0.185^{* * *} \\
(0.054)\end{array}$ & $\begin{array}{l}0.301 * * * \\
(0.043)\end{array}$ & $\begin{array}{l}0.208^{* * *} \\
(0.047)\end{array}$ & $\begin{array}{r}0.059 \\
(0.054)\end{array}$ & $\begin{array}{c}0.195^{*} \\
(0.107)\end{array}$ & $\begin{array}{l}0.114^{* * *} \\
(0.037)\end{array}$ & $\begin{array}{l}0.106^{* * *} \\
(0.035)\end{array}$ & $\begin{array}{l}0.242^{* * *} \\
(0.055)\end{array}$ & $\begin{array}{l}0.193^{* * *} \\
(0.058)\end{array}$ \\
\hline \multirow[t]{2}{*}{ Sales $(F)$} & 0.191 & 0.189 & 0.051 & $0.243^{* * *}$ & $0.172^{* * *}$ & $0.133^{* * *}$ & 0.054 & 0.037 & -0.007 & 0.029 & $0.150^{* *}$ & $0.152^{* * *}$ \\
\hline & $(0.172)$ & $(0.141)$ & $(0.060)$ & $(0.068)$ & $(0.037)$ & $(0.041)$ & $(0.043)$ & $(0.063)$ & $(0.045)$ & $(0.042)$ & $(0.059)$ & $(0.036)$ \\
\hline Craft Trade (F) & $\begin{array}{l}0.221^{* *} \\
(0.103)\end{array}$ & $\begin{array}{r}0.110 \\
(0.086)\end{array}$ & $\begin{array}{l}0.114^{* * *} \\
(0.035)\end{array}$ & $\begin{array}{l}0.110^{* * *} \\
(0.040)\end{array}$ & $\begin{array}{l}0.136^{* * *} \\
(0.028)\end{array}$ & $\begin{array}{l}0.113^{* * *} \\
(0.034)\end{array}$ & $\begin{array}{c}0.040^{*} \\
(0.024)\end{array}$ & $\begin{array}{l}0.104^{* *} \\
(0.047)\end{array}$ & $\begin{array}{l}0.051^{* *} \\
(0.024)\end{array}$ & $\begin{array}{r}0.027 \\
(0.030)\end{array}$ & $\begin{array}{l}0.081^{* *} \\
(0.033)\end{array}$ & $\begin{array}{c}0.159^{* * *} \\
(0.026)\end{array}$ \\
\hline \multirow[t]{2}{*}{ Machine opperation (F) } & $0.196^{*}$ & 0.088 & $0.086^{*}$ & 0.041 & $0.198^{* * *}$ & $0.166^{* * *}$ & $0.050^{*}$ & $0.100^{* *}$ & 0.006 & 0.007 & $0.109^{* * *}$ & $0.104^{* * *}$ \\
\hline & $(0.103)$ & $(0.085)$ & $(0.048)$ & $(0.049)$ & $(0.033)$ & $(0.037)$ & $(0.026)$ & $(0.047)$ & $(0.025)$ & $(0.03$ & $(0.034)$ & $(0.027)$ \\
\hline \multirow[t]{2}{*}{ Elementary Occ. $(\mathrm{F})$} & $0.188^{*}$ & $-0.273^{* * *}$ & 0.059 & -0.075 & 0.031 & -0.018 & 0.044 & -0.003 & -0.044 & $-0.059 * *$ & 0.023 & -0.009 \\
\hline & $(0.112)$ & $(0.106)$ & $(0.045)$ & $(0.065)$ & $(0.029)$ & $(0.037)$ & $(0.045)$ & $(0.068)$ & $(0.032)$ & $(0.028)$ & $(0.038)$ & $(0.030)$ \\
\hline \multirow[t]{2}{*}{ Armed/Military (F) } & 0.034 & -0.097 & 0.109 & 0.031 & $0.226^{* * *}$ & $0.347^{* * *}$ & $0.274^{* * *}$ & $0.267^{* *}$ & $0.172^{* * *}$ & $0.223^{* * *}$ & 0.073 & $0.166^{* * *}$ \\
\hline & $(0.149)$ & $(0.147)$ & $(0.115)$ & $(0.104)$ & $(0.066)$ & $(0.085$ & $(0.083)$ & $(0.130)$ & $(0.044)$ & $(0.066)$ & $(0.072)$ & $(0.060)$ \\
\hline Unemployed (F) & $\begin{array}{l}-0.093 \\
(0.478)\end{array}$ & $\begin{array}{l}-0.294^{* *} \\
(0.134)\end{array}$ & $\begin{array}{r}0.046 \\
(0.211)\end{array}$ & $\begin{array}{r}-0.046 \\
(0.158)\end{array}$ & $\begin{array}{l}0.317^{* * *} \\
(0.122)\end{array}$ & $\begin{array}{l}0.122^{* *} \\
(0.060)\end{array}$ & $\begin{array}{r}-0.042 \\
(0.033)\end{array}$ & $\begin{array}{l}0.137^{* *} \\
(0.060)\end{array}$ & $\begin{array}{r}0.176 \\
(0.133)\end{array}$ & $\begin{array}{r}-0.049 \\
(0.049)\end{array}$ & $\begin{array}{l}0.246^{* * *} \\
(0.082)\end{array}$ & $\begin{array}{l}0.117^{* *} \\
(0.049)\end{array}$ \\
\hline Difficulties most of the time & $\begin{array}{l}-0.252^{* *} \\
(0.100)\end{array}$ & $\begin{array}{r}0.237 \\
(0.197)\end{array}$ & & $\begin{array}{l}-0.288^{* * *} \\
(0.075)\end{array}$ & $\begin{array}{r}0.008 \\
(0.033)\end{array}$ & $\begin{array}{l}-0.215^{* * *} \\
(0.062)\end{array}$ & $\begin{array}{r}0.015 \\
(0.036)\end{array}$ & $\begin{array}{r}0.120 \\
(0.144)\end{array}$ & & $\begin{array}{r}0.009 \\
(0.046)\end{array}$ & $\begin{array}{l}-0.092^{* * *} \\
(0.032)\end{array}$ & $\begin{array}{l}-0.289^{* * *} \\
(0.044)\end{array}$ \\
\hline \multirow[t]{2}{*}{ Difficulties often } & $-0.112^{* *}$ & $-0.253^{* * *}$ & & $-0.118^{* *}$ & 0.003 & $-0.192^{* * *}$ & -0.024 & $\begin{array}{r}0.144) \\
0.088\end{array}$ & & -0.022 & $-0.068^{* *}$ & $-0.144^{* * *}$ \\
\hline & $(0.055)$ & $(0.082)$ & & $(0.057)$ & $(0.032)$ & $(0.038)$ & $(0.030)$ & $(0.075)$ & & $(0.032)$ & $(0.027)$ & $(0.029)$ \\
\hline Difficulties occasionally & 0.021 & $-0.087^{* *}$ & & $-0.081^{* *}$ & -0.040 & -0.020 & 0.012 & 0.016 & & $0.038^{* *}$ & $-0.059^{* *}$ & -0.019 \\
\hline & $(0.0$ & $(0.03$ & & $(0.03$ & $(0.0$ & $(0.0$ & $(0.022)$ & $(0.029)$ & & $(0.017)$ & $(0.027)$ & $(0.016)$ \\
\hline Difficulties never & -0.015 & $0.252^{* *}$ & & -0.016 & $0.066^{* * *}$ & -0.009 & -0.006 & $0.127^{* *}$ & & 0.009 & -0.003 & $-0.119^{* * *}$ \\
\hline & $(0.042)$ & $(0.105)$ & & $(0,0$ & & $(0.06$ & & $(0.0$ & & $(0.0$ & $(0.0$ & $(0.043)$ \\
\hline Other European Union & & & 0.031 & 0.021 & $-0.118^{*}$ & $-0.332^{* * *}$ & -0.078 & -0.031 & -0.044 & 0.055 & 0.062 & $0.310^{* * *}$ \\
\hline & & & $\begin{array}{l}(0.086) \\
-0.462 * * *\end{array}$ & $\begin{array}{l}(0.088) \\
-0.455 * *\end{array}$ & & & $\begin{array}{l}(0.091) \\
-0.184\end{array}$ & $(0.080)$ & $\begin{array}{l}(0.035) \\
-0219 * * *\end{array}$ & $(0.042)$ & & $\begin{array}{l}(0.073) \\
-0.578 * * *\end{array}$ \\
\hline Other outside EU & $\begin{array}{l}-0.026 \\
(0.042)\end{array}$ & $\begin{array}{l}-0.167^{* * *} \\
(0.051)\end{array}$ & $\begin{array}{l}-0.462^{* * *} \\
(0.047)\end{array}$ & $\begin{array}{l}-0.455^{* * *} \\
(0.049)\end{array}$ & $\begin{array}{l}-0.342^{* * *} \\
(0.038)\end{array}$ & $\begin{array}{l}-0.435^{* * *} \\
(0.030)\end{array}$ & $\begin{array}{r}-0.184 \\
(0.112)\end{array}$ & $\begin{array}{l}-0.260^{* * *} \\
(0.076)\end{array}$ & $\begin{array}{l}-0.219^{* * *} \\
(0.029)\end{array}$ & $\begin{array}{l}-0.313^{* * *} \\
(0.031)\end{array}$ & $\begin{array}{l}-0.029 \\
(0.059)\end{array}$ & $\begin{array}{l}-0.578^{* * *} \\
(0.129)\end{array}$ \\
\hline Woman & $\begin{array}{l}-0.153^{* * *} \\
(0.030)\end{array}$ & $\begin{array}{l}-0.088^{* * *} \\
(0.030)\end{array}$ & $\begin{array}{c}0.046^{*} \\
(0.025)\end{array}$ & $\begin{array}{r}0.015 \\
(0.028)\end{array}$ & $\begin{array}{l}-0.041^{* *} \\
(0.017)\end{array}$ & $\begin{array}{r}-0.006 \\
(0.019)\end{array}$ & $\begin{array}{r}-0.007 \\
(0.015)\end{array}$ & $\begin{array}{l}-0.048^{*} \\
(0.026)\end{array}$ & $\begin{array}{l}-0.024^{*} \\
(0.014)\end{array}$ & $\begin{array}{l}-0.069^{* * *} \\
(0.014)\end{array}$ & $\begin{array}{l}0.043^{* *} \\
(0.018)\end{array}$ & $\begin{array}{l}-0.023^{*} \\
(0.013)\end{array}$ \\
\hline R-Squared & 0.082 & 0.105 & 0.109 & 0.158 & 0.098 & 0.096 & 0.048 & 0.035 & 0.094 & 0.108 & 0.127 & 0.169 \\
\hline
\end{tabular}

Table A3.B 


\begin{tabular}{|c|c|c|c|c|c|c|c|c|c|c|c|c|}
\hline & \multicolumn{2}{|c|}{ IE } & \multicolumn{2}{|c|}{ IS } & \multicolumn{2}{|c|}{ IT } & \multicolumn{2}{|c|}{ LT } & \multicolumn{2}{|c|}{$\mathrm{LU}$} & \multicolumn{2}{|c|}{ LV } \\
\hline & 2004 & 2010 & 2004 & 2010 & 2004 & 2010 & 2004 & 2010 & 2004 & 2010 & 2004 & 2010 \\
\hline Constant & $9.853^{* * *}$ & ${ }^{9.951^{* * *}}$ & $9.925^{* * *}$ & $9.420^{* * *}$ & $9.647^{* * *}$ & $9.444^{* * *}$ & $7.496^{* * *}$ & $7.925^{* * *}$ & $10.314^{* * *}$ & $10.260^{* * *}$ & $7.560^{* * *}$ & $7.583^{* * *}$ \\
\hline \multirow[t]{2}{*}{ No Education (F) } & $-0.208^{*}$ & -0.144 & -0.092 & -0.418 & $-0.161^{* * *}$ & $-0.158^{* * *}$ & $-0.159^{* *}$ & 0.009 & $-0.134^{* *}$ & $-0.162 * * *$ & -0.157 & 0.488 \\
\hline & $(0.108)$ & $(0.167)$ & $(0.100)$ & $(0.413)$ & $(0.019)$ & $(0.049)$ & $(0.077)$ & $(0.176)$ & $(0.060)$ & $(0.051)$ & $(0.172)$ & $(0.583)$ \\
\hline Medium Level Education (F) & $\begin{array}{l}0.095^{* *} \\
(0.043)\end{array}$ & $\begin{array}{c}0.062 * \\
(0.036)\end{array}$ & $\begin{array}{r}0.020 \\
(0.041)\end{array}$ & $\begin{array}{l}0.128^{* *} \\
(0.052)\end{array}$ & $\begin{array}{l}0.139^{* * *} \\
(0.020)\end{array}$ & $\begin{array}{l}0.137^{* * *} \\
(0.023)\end{array}$ & $\begin{array}{c}0.077^{*} \\
(0.046)\end{array}$ & $\begin{array}{l}0.101^{* *} \\
(0.048)\end{array}$ & $\begin{array}{l}0.177^{* * *} \\
(0.028)\end{array}$ & $\begin{array}{l}0.118^{* * *} \\
(0.023)\end{array}$ & $\begin{array}{l}0.142^{* * *} \\
(0.049)\end{array}$ & $\begin{array}{l}0.167^{* * *} \\
(0.040)\end{array}$ \\
\hline High Level Education (F) & 0.043 & -0.007 & $0.137^{*}$ & $0.150^{*}$ & $0.200^{* * *}$ & $0.122^{* *}$ & $0.400^{* * *}$ & 0.090 & $0.265^{* * *}$ & $0.216^{* * *}$ & 0.119 & $0.171^{* *}$ \\
\hline No Education (M) & $\begin{array}{r}(0.060) \\
0.119 \\
(0.122)\end{array}$ & $\begin{array}{r}(0.058) \\
-0.202 \\
(0.166)\end{array}$ & $\begin{array}{r}(0.070) \\
-0.012 \\
(0.104)\end{array}$ & $\begin{array}{l}(0.086) \\
-2.134^{* * *} \\
(0.424)\end{array}$ & $\begin{array}{l}(0.039) \\
-0.160^{* * *} \\
(0.017)\end{array}$ & $\begin{array}{l}(0.048) \\
-0.210^{* * *} \\
(0.043)\end{array}$ & $\begin{array}{l}(0.085) \\
-0.158^{* *} \\
(0.069)\end{array}$ & $\begin{array}{l}(0.088) \\
-0.023 \\
(0.159)\end{array}$ & $\begin{array}{l}(0.055) \\
-0.119^{* *} \\
(0.050)\end{array}$ & $\begin{array}{l}(0.039) \\
-0.011 \\
(0.039)\end{array}$ & $\begin{array}{l}(0.092) \\
-0.354^{* *} \\
(0.141)\end{array}$ & $\begin{array}{c}(0.070) \\
-0.285 \\
(0.535)\end{array}$ \\
\hline Medium Level Education (M) & $\begin{array}{l}0.171^{* * *} \\
(0.040)\end{array}$ & $\begin{array}{r}-0.005 \\
(0.033)\end{array}$ & $\begin{array}{r}0.045 \\
(0.038)\end{array}$ & $\begin{array}{l}-0.178^{* * *} \\
(0.047)\end{array}$ & $\begin{array}{l}0.078^{* * *} \\
(0.023)\end{array}$ & $\begin{array}{l}0.149^{* * *} \\
(0.024)\end{array}$ & $\begin{array}{l}0.138^{* * *} \\
(0.045)\end{array}$ & $\begin{array}{r}0.003 \\
(0.046)\end{array}$ & $\begin{array}{l}0.068^{* *} \\
(0.031)\end{array}$ & $\begin{array}{l}0.093^{* * *} \\
(0.023)\end{array}$ & $\begin{array}{l}0.194^{* * *} \\
(0.046)\end{array}$ & $\begin{array}{l}0.096^{* *} \\
(0.039)\end{array}$ \\
\hline High Level Education (M) & $\begin{array}{l}0.165^{* * *} \\
(0.055)\end{array}$ & $\begin{array}{r}0.079 \\
(0.053)\end{array}$ & $\begin{array}{r}-0.079 \\
(0.068)\end{array}$ & $\begin{array}{r}-0.017 \\
(0.077)\end{array}$ & $\begin{array}{l}0.193^{* * *} \\
(0.054)\end{array}$ & $\begin{array}{l}0.251^{* * *} \\
(0.049)\end{array}$ & $\begin{array}{l}0.230^{* * *} \\
(0.073)\end{array}$ & $\begin{array}{l}0.205^{* * *} \\
(0.074)\end{array}$ & $\begin{array}{l}0.125^{* *} \\
(0.051)\end{array}$ & $\begin{array}{l}0.163^{* * *} \\
(0.038)\end{array}$ & $\begin{array}{l}0.364^{* * *} \\
(0.074)\end{array}$ & $\begin{array}{l}0.294^{* * *} \\
(0.057)\end{array}$ \\
\hline Managerial (F) & $\begin{array}{r}0.109 \\
(0.094)\end{array}$ & $0^{0.272^{* * *}}$ & $0.099^{*}$ & $\begin{array}{l}-0.108 \\
(0.079)\end{array}$ & $0.120^{* * *}$ & $0.158^{* * *}$ & $0.191 *$ & $\begin{array}{r}0.157 \\
(0.104)\end{array}$ & 0.011 & $0.202^{* * *}$ & $\begin{array}{r}0.128 \\
(0.133)\end{array}$ & $0.356^{* * *}$ \\
\hline Professional (F) & $\begin{array}{l}0.227^{* *} \\
(0.105)\end{array}$ & $\begin{array}{l}0.295^{* * *} \\
(0.066)\end{array}$ & $\begin{array}{c}0.149^{* *} \\
(0.075)\end{array}$ & $\begin{array}{l}-0.175^{*} \\
(0.095)\end{array}$ & $\begin{array}{r}0.031 \\
(0.041)\end{array}$ & $\begin{array}{l}0.206^{* * *} \\
(0.047)\end{array}$ & $\begin{array}{r}0.126 \\
(0.095)\end{array}$ & $\begin{array}{r}0.157 \\
(0.099)\end{array}$ & $\begin{array}{r}-0.020 \\
(0.066)\end{array}$ & $\begin{array}{l}0.267^{* * *} \\
(0.045)\end{array}$ & $\begin{array}{r}0.196 \\
(0.140)\end{array}$ & $\begin{array}{c}0.298^{* * *} \\
(0.089)\end{array}$ \\
\hline Technical (F) & $\begin{array}{c}0.198^{*} \\
(0.114)\end{array}$ & $\begin{array}{c}0.120^{*} \\
(0.070)\end{array}$ & $\begin{array}{r}0.077 \\
(0.064)\end{array}$ & $\begin{array}{r}-0.116 \\
(0.095)\end{array}$ & $\begin{array}{l}0.120^{* * *} \\
(0.028)\end{array}$ & $\begin{array}{l}0.194^{* * *} \\
(0.035)\end{array}$ & $\begin{array}{c}0.262^{* *} \\
(0.109)\end{array}$ & $\begin{array}{l}0.257^{* *} \\
(0.115)\end{array}$ & $\begin{array}{r}0.060 \\
(0.045)\end{array}$ & $\begin{array}{l}0.165 * * * \\
(0.038)\end{array}$ & $\begin{array}{r}0.199 \\
(0.131)\end{array}$ & $\begin{array}{c}0.180^{*} \\
(0.094)\end{array}$ \\
\hline \multirow{2}{*}{ Clerical (F) } & 0.142 & 0.058 & $-0.330^{* * *}$ & -0.044 & $0.106^{* * *}$ & $0.177^{* * *}$ & $0.441 * * *$ & $0.294^{* *}$ & $0.100 *$ & $0.159^{* * *}$ & 0.124 & 0.251 \\
\hline & $(0.103)$ & $(0.098)$ & $(0.122)$ & $(0.151)$ & $(0.029)$ & $(0.037)$ & $(0.130)$ & $(0.139)$ & $(0.058)$ & $(0.046)$ & $(0.189)$ & $(0.169)$ \\
\hline \multirow[t]{2}{*}{ Sales $(F)$} & 0.112 & -0.052 & $0.134 *$ & -0.071 & 0.006 & 0.044 & $0.522 * * *$ & 0.020 & -0.075 & $-0.088^{*}$ & 0.117 & 0.015 \\
\hline & $(0.104)$ & $(0.060)$ & $(0.078)$ & $(0.084)$ & $(0.032)$ & $(0.035)$ & $(0.128)$ & $(0.122)$ & $(0.063)$ & $(0.049)$ & $(0.162)$ & $(0.121)$ \\
\hline \multirow[t]{2}{*}{ Craft Trade (F) } & 0.123 & -0.058 & 0.052 & -0.047 & $0.043^{* *}$ & $0.076^{* * *}$ & $0.163^{* *}$ & 0.060 & -0.063 & 0.027 & 0.028 & $0.210^{* * *}$ \\
\hline & $(0.095)$ & $(0.050)$ & $(0.053)$ & $(0.068)$ & $(0.019)$ & $(0.027)$ & $(0.073)$ & $(0.070)$ & $(0.039)$ & $(0.031)$ & $(0.109)$ & $(0.069)$ \\
\hline \multirow{2}{*}{ Machine opperation (F) } & 0.131 & $-0.155^{* *}$ & 0.002 & 0.042 & $0.073^{* * *}$ & $0.068^{* *}$ & 0.088 & -0.026 & -0.041 & 0.002 & 0.087 & $0.180^{* * *}$ \\
\hline & $(0.098)$ & $(0.063)$ & $(0.069)$ & $(0.084)$ & $(0.022)$ & $(0.031)$ & $(0.072)$ & $(0.071)$ & $(0.038)$ & $(0.033)$ & $(0.109)$ & $(0.068)$ \\
\hline \multirow[t]{2}{*}{ Elementary Occ. $(\mathrm{F})$} & -0.005 & $-0.203^{* * *}$ & 0.098 & -0.180 & $-0.088^{* * *}$ & $\begin{array}{l}-0.048 \\
\end{array}$ & $0.127^{*}$ & 0.045 & 0.008 & -0.028 & 0.019 & 0.127 \\
\hline & $(0.095)$ & $(0.052)$ & $(0.087)$ & $(0.110)$ & $(0.022)$ & $(0.031)$ & $(0.073)$ & $(0.073)$ & $(0.062)$ & $(0.048)$ & $(0.116)$ & $(0.080)$ \\
\hline \multirow[t]{2}{*}{ Armed/Military (F) } & 0.092 & -0.086 & -0.400 & -0.485 & $0.240^{* * *}$ & $0.201^{* * *}$ & 0.091 & $-0.426^{*}$ & 0.149 & 0.095 & $0.360^{* *}$ & 0.086 \\
\hline & $(0.126)$ & $(0.098)$ & $(0.499)$ & $(0.428)$ & $(0.045)$ & $(0.062)$ & $(0.186)$ & $(0.240)$ & $(0.125)$ & $(0.081)$ & $(0.170)$ & $(0.133)$ \\
\hline \multirow[t]{2}{*}{ Unemployed (F) } & 0.032 & $-0.274^{* * *}$ & 0.146 & 0.057 & 0.025 & $-0.081 * *$ & 0.259 & 0.274 & 0.038 & 0.017 & 0.049 & 0.011 \\
\hline & $(0.106)$ & $(0.061)$ & $(0.175)$ & $(0.189)$ & $(0.029)$ & $(0.039)$ & $(0.167)$ & $(0.202)$ & $(0.272)$ & $(0.069)$ & $(0.226)$ & $(0.129)$ \\
\hline Difficulties most of the time & $-0.147^{* * *}$ & $-0.137^{*}$ & 0.063 & -0.106 & $-0.163^{* * *}$ & $-0.094^{* *}$ & $-0.173^{* * *}$ & $-1.167^{* * *}$ & $-0.216^{* * *}$ & -0.073 & -0.130 & $0.357^{* *}$ \\
\hline & $(0.046)$ & $(0.080)$ & $(0.102)$ & $(0.122)$ & $(0.020)$ & $(0.044)$ & $(0.066)$ & $(0.142)$ & $(0.053)$ & $(0.052)$ & $(0.089)$ & $(0.146)$ \\
\hline Difficulties often & $-0.139^{* * *}$ & 0.048 & -0.014 & -0.156 & $-0.106^{* * *}$ & $-0.078^{* *}$ & $-0.088^{*}$ & -0.091 & -0.029 & $-0.116^{* * *}$ & -0.001 & 0.021 \\
\hline & $(0.046)$ & $(0.058)$ & $(0.086)$ & $(0.099)$ & $(0.018)$ & $(0.032)$ & $(0.053)$ & $(0.075)$ & $(0.041)$ & $(0.036)$ & $(0.066)$ & $(0.087)$ \\
\hline Difficulties occasionally & -0.008 & 0.028 & 0.043 & -0.057 & $-0.074^{* * *}$ & 0.012 & -0.053 & -0.050 & -0.018 & $-0.037^{*}$ & -0.027 & $0.064^{*}$ \\
\hline & $(0.033)$ & $(0.033)$ & $(0.057)$ & $(0.053)$ & $(0.016)$ & $(0.018)$ & $(0.046)$ & $(0.039)$ & $(0.034)$ & $(0.019)$ & $(0.055)$ & $(0.036)$ \\
\hline Difficulties never & $0.092^{* * *}$ & 0.016 & 0.073 & $-0.387^{* * *}$ & $0.044^{* *}$ & $-0.195^{* * *}$ & -0.034 & -0.040 & $0.078^{* * *}$ & $-0.095^{* *}$ & -0.026 & -0.081 \\
\hline & $(0.029)$ & $(0.057)$ & $(0.046)$ & $(0.081)$ & & $(0.052)$ & $(0.046)$ & $(0.105)$ & & $(0.037)$ & $(0.052)$ & $(0.067)$ \\
\hline Other European Union & $-0.087^{* *}$ & $-0.119^{* * *}$ & $-0.204^{* *}$ & $\begin{array}{l}-0.002 \\
(0.080)\end{array}$ & $-0.104^{* *}$ & $-0.213^{* * *}$ & $\begin{array}{r}0.057 \\
0.275)\end{array}$ & $\begin{array}{r}0.225 \\
(0.347)\end{array}$ & $-0.112^{* * *}$ & $-0.168^{* * *}$ & & \\
\hline Other outside EU & $\begin{array}{r}-0.081 \\
(0.065)\end{array}$ & $-0.160^{* * *}$ & $\begin{array}{r}-0.052 \\
-0.105)\end{array}$ & $\begin{array}{r}0.105 \\
(0.109)\end{array}$ & $-0.235 * * *$ & $-0.224^{* * *}$ & $\begin{array}{r}-0.010 \\
-0.067)\end{array}$ & $\begin{array}{l}-0.098 \\
(0.083)\end{array}$ & $-0.390^{* * *}$ & $-0.380^{* * *}$ & 0.003 & -0.090 \\
\hline Woman & $\begin{array}{l}-0.147^{* * *} \\
(0.023)\end{array}$ & $\begin{array}{l}-0.071^{* *} \\
(0.028)\end{array}$ & $\begin{array}{r}0.001 \\
(0.032)\end{array}$ & $\begin{array}{r}0.063 \\
(0.041)\end{array}$ & $\begin{array}{l}0.036^{* * *} \\
(0.012)\end{array}$ & $\begin{array}{r}0.013 \\
(0.015)\end{array}$ & $\begin{array}{c}-0.035 \\
(0.031)\end{array}$ & $\begin{array}{l}-0.076^{* *} \\
(0.035)\end{array}$ & $\begin{array}{l}-0.132^{* * *} \\
(0.023)\end{array}$ & $\begin{array}{l}-0.090^{* * *} \\
(0.017)\end{array}$ & $\begin{array}{l}-0.117^{* * *} \\
(0.036)\end{array}$ & $\begin{array}{r}-0.029 \\
(0.031)\end{array}$ \\
\hline R-Squared & 0.127 & 0.136 & 0.057 & 0.078 & 0.138 & 0.091 & 0.117 & 0.082 & 0.233 & 0.256 & 0.112 & 0.071 \\
\hline
\end{tabular}

Table A3.C 


\begin{tabular}{|c|c|c|c|c|c|c|c|c|c|c|c|c|}
\hline & \multicolumn{2}{|c|}{$\mathrm{NE}$} & \multicolumn{2}{|c|}{$\mathrm{NO}$} & \multicolumn{2}{|c|}{$\mathrm{PL}$} & \multicolumn{2}{|c|}{$\mathrm{PT}$} & \multicolumn{2}{|c|}{$\mathrm{SE}$} & \multicolumn{2}{|c|}{ SI } \\
\hline & 2004 & 2010 & 2004 & 2010 & 2004 & 2010 & 2004 & 2010 & 2004 & 2010 & 2004 & 2010 \\
\hline \multirow[t]{2}{*}{ Constant } & $9.645^{* * *}$ & $9.821 * * *$ & $10.231^{* * *}$ & $10.392^{* * *}$ & $7.591^{* * *}$ & $8.118^{* * *}$ & $8.892^{* * *}$ & $9.013^{* *}$ & $9.807^{* * *}$ & $9.945^{*}$ & $9.053^{* * *}$ & $9.071^{* * *}$ \\
\hline & $(0.071)$ & $(0.032)$ & $(0.034)$ & $(0.038)$ & $(0.027)$ & $(0.024)$ & $(0.039)$ & $(0.046)$ & $(0.020)$ & $(0.030)$ & $(0.033)$ & $(0.042)$ \\
\hline No Education (F) & & $\begin{array}{r}-0.088 \\
(0.115)\end{array}$ & & -0.060 & $\begin{array}{l}-0.046 \\
\end{array}$ & $\begin{array}{r}0.107 \\
(0.295)\end{array}$ & $-0.162^{* * *}$ & $-0.103^{* * *}$ & 0.058 & & -0.062 & $\begin{array}{r}-0.132 \\
(0.413)\end{array}$ \\
\hline \multirow{2}{*}{ Medium Level Education (F) } & $0.056^{* *}$ & 0.028 & 0.027 & $\begin{array}{r}(0.191) \\
-0.033\end{array}$ & $0.044^{*}$ & $0.058^{* *}$ & $0.194^{* *}$ & $\begin{array}{r}(0.009) \\
0.109\end{array}$ & $0.078^{* * *}$ & 0.040 & $0.092^{* * *}$ & $\begin{array}{r}(0.410) \\
0.014\end{array}$ \\
\hline & $(0.025)$ & $(0.021)$ & $(0.021)$ & $(0.027)$ & $(0.026)$ & $(0.025)$ & $(0.096)$ & $(0.073)$ & $(0.028)$ & $(0.028)$ & $(0.023)$ & $(0.026)$ \\
\hline \multirow[t]{2}{*}{ High Level Education (F) } & $0.078^{* *}$ & -0.001 & $0.096^{* * *}$ & 0.026 & $0.105^{*}$ & $0.109^{* *}$ & 0.178 & $0.335^{* * *}$ & $0.116^{* * *}$ & 0.043 & $0.146^{* *}$ & -0.067 \\
\hline & $(0.031)$ & $(0.027)$ & $(0.031)$ & $(0.035)$ & $(0.059)$ & $(0.047)$ & $(0.133)$ & $(0.087)$ & $(0.029)$ & $(0.037)$ & $(0.058)$ & $(0.051)$ \\
\hline No Education (M) & & $\begin{array}{r}0.125 \\
(0.088)\end{array}$ & & $\begin{array}{r}-0.020 \\
(0.108)\end{array}$ & $\begin{array}{r}-0.058 \\
(0.040)\end{array}$ & $\begin{array}{r}-0.073 \\
(0.302)\end{array}$ & $\begin{array}{l}-0.125^{* * *} \\
(0.034)\end{array}$ & $\begin{array}{l}-0.229^{* * *} \\
(0.033)\end{array}$ & $\begin{array}{l}-0.252^{* *} \\
(0.108)\end{array}$ & & $\begin{array}{r}0.025 \\
(0.047)\end{array}$ & $\begin{array}{l}-0.394^{*} \\
(0.213)\end{array}$ \\
\hline Medium Level Education (M) & $\begin{array}{r}0.038 \\
(0.028)\end{array}$ & $\begin{array}{l}0.051^{* * * *} \\
(0.019)\end{array}$ & $\begin{array}{r}-0.015 \\
(0.021)\end{array}$ & $\begin{array}{r}0.021 \\
(0.025)\end{array}$ & $\begin{array}{l}0.176^{* * *} \\
(0.025)\end{array}$ & $\begin{array}{l}0.122^{* * *} \\
(0.024)\end{array}$ & $\begin{array}{r}0.111 \\
(0.117)\end{array}$ & $\begin{array}{r}0.108 \\
(0.074)\end{array}$ & $\begin{array}{r}-0.012 \\
(0.027)\end{array}$ & $\begin{array}{r}-0.033 \\
(0.029)\end{array}$ & $\begin{array}{c}0.043^{*} \\
(0.023)\end{array}$ & $\begin{array}{l}0.096^{* * *} \\
(0.025)\end{array}$ \\
\hline High Level Education (M) & $\begin{array}{r}0.002 \\
(0.037)\end{array}$ & $\begin{array}{l}0.117^{* * *} \\
(0.029)\end{array}$ & $\begin{array}{l}-0.043^{*} \\
(0.024)\end{array}$ & $\begin{array}{l}0.075^{* *} \\
(0.031)\end{array}$ & $\begin{array}{l}0.371^{* * * *} \\
(0.053)\end{array}$ & $\begin{array}{l}0.253^{* * *} \\
(0.042)\end{array}$ & $\begin{array}{l}0.315^{* * *} \\
(0.094)\end{array}$ & $\begin{array}{c}0.137^{*} \\
(0.072)\end{array}$ & $\begin{array}{r}0.046 \\
(0.031)\end{array}$ & $\begin{array}{l}-0.002 \\
(0.034)\end{array}$ & $\begin{array}{r}0.020 \\
(0.071)\end{array}$ & $\begin{array}{l}0.128^{* * *} \\
(0.035)\end{array}$ \\
\hline Managerial (F) & $\begin{array}{l}0.143^{* *} \\
(0.072)\end{array}$ & $\begin{array}{l}0.148^{* * *} \\
(0.041)\end{array}$ & $\begin{array}{r}0.032 \\
(0.037)\end{array}$ & $\begin{array}{c}0.072^{*} \\
(0.043)\end{array}$ & $\begin{array}{l}0.237^{* * *} \\
(0.053)\end{array}$ & $\begin{array}{l}0.290^{* * * *} \\
(0.046)\end{array}$ & $\begin{array}{l}0.361^{* * *} \\
(0.063)\end{array}$ & $\begin{array}{l}0.198^{* * *} \\
(0.060)\end{array}$ & $\begin{array}{r}0.052 \\
(0.074)\end{array}$ & $\begin{array}{l}-0.065 \\
(0.117)\end{array}$ & $\begin{array}{l}0.161^{* * *} \\
(0.055)\end{array}$ & $\begin{array}{l}0.268^{* * *} \\
(0.068)\end{array}$ \\
\hline Professional (F) & $\begin{array}{l}0.156^{* *} \\
(0.077)\end{array}$ & $\begin{array}{l}0.105^{* * *} \\
(0.040)\end{array}$ & $\begin{array}{l}0.100^{* *} \\
(0.044)\end{array}$ & $\begin{array}{r}0.056 \\
(0.047)\end{array}$ & $\begin{array}{l}0.310^{* * *} \\
(0.063)\end{array}$ & $\begin{array}{l}0.342^{* * *} \\
(0.048)\end{array}$ & $\begin{array}{l}0.495^{* * *} \\
(0.141)\end{array}$ & $\begin{array}{r}0.094 \\
(0.083)\end{array}$ & $\begin{array}{l}-0.075 \\
(0.052)\end{array}$ & $\begin{array}{l}-0.075 \\
(0.062)\end{array}$ & $\begin{array}{l}0.155^{* * *} \\
(0.055)\end{array}$ & $\begin{array}{l}0.288^{* * *} \\
(0.065)\end{array}$ \\
\hline Technical (F) & $\begin{array}{l}0.234^{* * *} \\
(0.074)\end{array}$ & $\begin{array}{l}0.089^{* *} \\
(0.036)\end{array}$ & $\begin{array}{r}0.033 \\
(0.035)\end{array}$ & $\begin{array}{r}0.020 \\
(0.041)\end{array}$ & $\begin{array}{l}0.255^{* * *} \\
(0.040)\end{array}$ & $\begin{array}{l}0.297^{* * * *} \\
(0.038)\end{array}$ & $\begin{array}{l}0.527^{* * *} \\
(0.088)\end{array}$ & $\begin{array}{l}0.218^{* * *} \\
(0.057)\end{array}$ & $\begin{array}{l}-0.011 \\
(0.051)\end{array}$ & $\begin{array}{r}0.047 \\
(0.090)\end{array}$ & $\begin{array}{c}0.072^{*} \\
(0.039)\end{array}$ & $\begin{array}{r}0.010 \\
(0.046)\end{array}$ \\
\hline Clerical (F) & $\begin{array}{l}0.211 \text { *** } \\
(0.078)\end{array}$ & $\begin{array}{l}0.095^{* *} \\
(0.046)\end{array}$ & $\begin{array}{r}0.037 \\
(0.049)\end{array}$ & $\begin{array}{r}0.047 \\
(0.062)\end{array}$ & $\begin{array}{l}0.209^{* * *} \\
(0.052)\end{array}$ & $\begin{array}{l}0.260^{* * *} \\
(0.051)\end{array}$ & $\begin{array}{l}0.275^{* * *} \\
(0.069)\end{array}$ & $\begin{array}{l}0.319^{* * *} \\
(0.065)\end{array}$ & $\begin{array}{r}-0.016 \\
(0.074)\end{array}$ & $\begin{array}{r}-0.033 \\
(0.133)\end{array}$ & $\begin{array}{c}0.084^{*} \\
(0.045)\end{array}$ & $\begin{array}{l}0.133^{* *} \\
(0.056)\end{array}$ \\
\hline Sales $(F)$ & $\begin{array}{r}-0.014 \\
(0.083)\end{array}$ & $\begin{array}{l}0.133^{* * *} \\
(0.042)\end{array}$ & $\begin{array}{r}0.019 \\
(0.046)\end{array}$ & $\begin{array}{r}-0.032 \\
(0.051)\end{array}$ & $\begin{array}{l}0.130^{* *} \\
(0.060)\end{array}$ & $\begin{array}{l}0.211^{* * *} \\
(0.043)\end{array}$ & $\begin{array}{l}0.276^{* * *} \\
(0.066)\end{array}$ & $\begin{array}{l}0.189^{* * *} \\
(0.050)\end{array}$ & $\begin{array}{r}0.058 \\
(0.074)\end{array}$ & $\begin{array}{r}0.085 \\
(0.073)\end{array}$ & $\begin{array}{c}0.075 * \\
(0.045)\end{array}$ & $\begin{array}{r}0.071 \\
(0.050)\end{array}$ \\
\hline Craft Trade $(\mathrm{F})$ & $\begin{array}{c}0.119^{*} \\
(0.072)\end{array}$ & $\begin{array}{r}0.024 \\
(0.034)\end{array}$ & $\begin{array}{r}0.010 \\
(0.032)\end{array}$ & $\begin{array}{r}-0.046 \\
(0.037)\end{array}$ & $\begin{array}{l}0.136^{* * *} \\
(0.025)\end{array}$ & $\begin{array}{l}0.180^{* * *} \\
(0.024)\end{array}$ & $\begin{array}{l}0.092^{* *} \\
(0.041)\end{array}$ & $\begin{array}{r}-0.026 \\
(0.037)\end{array}$ & $\begin{array}{r}-0.038 \\
(0.033)\end{array}$ & $\begin{array}{r}0.016 \\
(0.051)\end{array}$ & $\begin{array}{c}-0.056^{*} \\
(0.031)\end{array}$ & $\begin{array}{r}0.022 \\
(0.038)\end{array}$ \\
\hline Machine opperation (F) & $\begin{array}{r}0.118 \\
(0.075)\end{array}$ & $\begin{array}{r}0.041 \\
(0.042)\end{array}$ & $\begin{array}{r}0.000 \\
(0.034)\end{array}$ & $\begin{array}{r}0.002 \\
(0.044)\end{array}$ & $\begin{array}{l}0.152^{* * *} \\
(0.028)\end{array}$ & $\begin{array}{l}0.180^{* * *} \\
(0.026)\end{array}$ & $\begin{array}{r}0.068 \\
(0.051)\end{array}$ & $\begin{array}{r}0.022 \\
(0.044)\end{array}$ & 0.014 & 0.013 & -0.005 & 0.011 \\
\hline Elementary Occ. (F) & $\begin{array}{r}0.105 \\
(0.081)\end{array}$ & $\begin{array}{r}(0.042) \\
0.004 \\
(0.055)\end{array}$ & $\begin{array}{r}0.034) \\
0.053 \\
(0.093)\end{array}$ & $\begin{array}{r}(0.044) \\
0.030 \\
(0.070)\end{array}$ & $\begin{array}{r}(.028) \\
0.016 \\
(0.033)\end{array}$ & $\begin{array}{c}0.061 * \\
0.034)\end{array}$ & $\begin{array}{l}0.108^{* *} \\
(0.050)\end{array}$ & $\begin{array}{c}0.124^{* *} \\
(0.052)\end{array}$ & $\begin{array}{r}0.048) \\
0.230 \\
(0.174)\end{array}$ & $\begin{array}{r}(0.071) \\
0.053 \\
(0.195)\end{array}$ & $\begin{array}{r}(0.030) \\
-0.032 \\
(0.044)\end{array}$ & $\begin{array}{l}(0.043) \\
-0.087^{* *} \\
(0.040)\end{array}$ \\
\hline \multirow[t]{2}{*}{ Armed/Military (F) } & 0.101 & 0.101 & $0.167^{* *}$ & 0.106 & $0.252^{* * *}$ & $0.389^{* * *}$ & $0.659^{* * *}$ & $(0.052)$ & 0.082 & $\begin{array}{r}(0.195) \\
0.018\end{array}$ & $\begin{array}{r}(0.044) \\
0.005\end{array}$ & $0.477^{* * *}$ \\
\hline & $(0.099)$ & $(0.068)$ & $(0.079)$ & $(0.076)$ & $(0.069)$ & $(0.075)$ & $(0.126)$ & & $(0.127)$ & $(0.280)$ & $(0.099)$ & $(0.153)$ \\
\hline \multirow[t]{2}{*}{ Unemployed (F) } & 0.066 & -0.015 & -0.010 & 0.030 & 0.082 & $0.184^{* * *}$ & 0.345 & -0.071 & -0.064 & -0.069 & 0.104 & -0.076 \\
\hline & $(0.079)$ & $(0.050)$ & $(0.085)$ & $(0.086)$ & $(0.072)$ & $(0.058)$ & $(0.603)$ & $(0.072)$ & $(0.065)$ & $(0.108)$ & $(0.108)$ & $(0.052)$ \\
\hline \multirow[t]{2}{*}{ Difficulties most of the time } & -0.050 & 0.110 & 0.048 & -0.038 & $-0.157^{* * *}$ & $-0.217^{* * *}$ & & $-0.249^{* * *}$ & 0.018 & -0.047 & -0.015 & 0.049 \\
\hline & $(0.059)$ & $(0.078)_{* * *}$ & $(0.068)$ & $(0.113)$ & $(0.035)_{* * *}$ & $(0.069)$ & & $(0.057)^{* * *}$ & $(0.047)$ & $(0.081)$ & $(0.033)$ & $(0.044)_{* * *}$ \\
\hline Difficulties often & $\begin{array}{c}-0.042 \\
(0.039)\end{array}$ & $\begin{array}{l}-0.152^{* * *} \\
(0.045)\end{array}$ & $\begin{array}{r}-0.056 \\
(0.044)\end{array}$ & $\begin{array}{r}-0.057 \\
(0.058)\end{array}$ & $\begin{array}{l}-0.094^{* * *} \\
(0.029)\end{array}$ & $\begin{array}{l}-0.174^{* * *} \\
(0.035)\end{array}$ & & $\begin{array}{l}-0.193^{* * *} \\
(0.046)\end{array}$ & $\begin{array}{r}-0.001 \\
(0.039)\end{array}$ & $\begin{array}{l}-0.086 \\
(0.054)\end{array}$ & $\begin{array}{r}-0.009 \\
(0.028)\end{array}$ & $\begin{array}{l}0.105^{* * *} \\
(0.036)\end{array}$ \\
\hline Difficulties occasionally & 0.049 & 0.026 & -0.021 & -0.022 & $-0.043^{*}$ & -0.019 & & -0.012 & 0.008 & 0.011 & 0.003 & $0.104^{* * *}$ \\
\hline & $(0.030)$ & $(0.018)$ & $(0.029)$ & $(0.021)$ & $(0.025)$ & $(0.018)$ & & $(0.034)$ & $(0.029)$ & $(0.026)$ & $(0.025)$ & $(0.025)$ \\
\hline Difficulties never & 0.034 & 0.026 & 0.029 & $-0.106^{* * *}$ & 0.024 & -0.041 & & 0.122 & $0.041^{*}$ & 0.022 & 0.020 & 0.057 \\
\hline & $(0.023)$ & $(0.028)$ & $(0.020)$ & $(0.036)$ & $(0.025)$ & $(0.047)$ & & $(0.110)$ & $(0.021)$ & $(0.037)$ & $(0.029)$ & $(0.047)$ \\
\hline Other European Union & 0.012 & -0.061 & 0.004 & 0.065 & 0.117 & -0.392 & 0.004 & $0.124^{*}$ & 0.000 & -0.031 & & \\
\hline & $(0.078)$ & $(0.058)$ & $(0.052)$ & $(0.056)$ & $(0.346)$ & $(0.589)$ & $(0.118)$ & $(0.071)$ & $(0.039)$ & $(0.081)$ & & \\
\hline Other outside EU & $\begin{array}{l}-0.189^{* * *} \\
(0.046)\end{array}$ & $\begin{array}{l}-0.168^{* * *} \\
(0.029)\end{array}$ & $\begin{array}{l}-0.235 * * * \\
(0.050)\end{array}$ & $\begin{array}{l}-0.200^{* * *} \\
(0.047)\end{array}$ & $\begin{array}{r}0.006 \\
(0.168)\end{array}$ & $\begin{array}{l}-0.143 \\
(0.320)\end{array}$ & $\begin{array}{c}-0.022 \\
(0.104)\end{array}$ & $\begin{array}{l}-0.077^{*} \\
(0.046)\end{array}$ & $\begin{array}{l}-0.226^{* * *} \\
(0.037)\end{array}$ & $\begin{array}{l}-0.215^{* * *} \\
(0.064)\end{array}$ & $\begin{array}{l}-0.124^{* * *} \\
(0.029)\end{array}$ & $\begin{array}{l}-0.143^{* * *} \\
(0.027)\end{array}$ \\
\hline Woman & $\begin{array}{l}-0.017 \\
(0.018)\end{array}$ & $\begin{array}{l}-0.015 \\
(0.016)\end{array}$ & $\begin{array}{l}-0.072^{* * *} \\
(0.017)\end{array}$ & $\begin{array}{r}0.003 \\
(0.019)\end{array}$ & $\begin{array}{l}0.083^{* * *} \\
(0.017)\end{array}$ & $\begin{array}{l}0.036^{* *} \\
(0.016)\end{array}$ & $\begin{array}{r}0.037 \\
(0.029)\end{array}$ & $\begin{array}{r}0.026 \\
(0.024)\end{array}$ & $\begin{array}{r}-0.011 \\
(0.017)\end{array}$ & $\begin{array}{l}-0.016 \\
(0.023)\end{array}$ & $\begin{array}{r}0.015 \\
(0.017)\end{array}$ & $\begin{array}{l}0.064^{* * *} \\
(0.017)\end{array}$ \\
\hline R-Squared & 0.039 & 0.050 & 0.055 & 0.050 & 0.096 & 0.111 & 0.179 & 0.188 & 0.070 & 0.019 & 0.083 & 0.091 \\
\hline
\end{tabular}

Table A3.D 


\begin{tabular}{|c|c|c|c|c|}
\hline & \multicolumn{2}{|c|}{ SK } & \multicolumn{2}{|c|}{ UK } \\
\hline & 2004 & 2010 & 2004 & 2010 \\
\hline Constant & $\begin{array}{l}7.841^{* * *} \\
(0.058)\end{array}$ & $\begin{array}{l}8.390 * * * \\
(0.072)\end{array}$ & $\begin{array}{l}10.281^{* * *} \\
(0.186)\end{array}$ & $\begin{array}{l}9.646^{* * *} \\
(0.070)\end{array}$ \\
\hline No Education (F) & & $\begin{array}{r}-0.079 \\
(0.559)\end{array}$ & $\begin{array}{l}-0.055 \\
(0.049)\end{array}$ & $\begin{array}{l}-0.159^{*} \\
(0.093)\end{array}$ \\
\hline Medium Level Education (F) & $\begin{array}{c}0.048^{*} \\
(0.027)\end{array}$ & $\begin{array}{r}0.018 \\
(0.030)\end{array}$ & $\begin{array}{c}0.092^{*} \\
(0.050)\end{array}$ & $\begin{array}{r}0.019 \\
(0.028)\end{array}$ \\
\hline High Level Education (F) & $\begin{array}{r}0.061 \\
(0.048)\end{array}$ & $\begin{array}{l}0.181^{* * *} \\
(0.057)\end{array}$ & $\begin{array}{l}0.212^{* * *} \\
(0.056)\end{array}$ & $\begin{array}{l}0.101^{* * *} \\
(0.038)\end{array}$ \\
\hline No Education (M) & & & $\begin{array}{l}-0.176^{* * *} \\
(0.044)\end{array}$ & $\begin{array}{r}-0.010 \\
(0.083)\end{array}$ \\
\hline Medium Level Education (M) & $\begin{array}{l}0.067^{* * *} \\
(0.024)\end{array}$ & $\begin{array}{l}0.134^{* * *} \\
(0.028)\end{array}$ & $\begin{array}{l}-0.193^{* * *} \\
(0.056)\end{array}$ & $\begin{array}{r}0.060 \\
(0.037)\end{array}$ \\
\hline High Level Education (M) & $\begin{array}{r}0.030 \\
(0.054)\end{array}$ & $\begin{array}{l}0.188^{* * *} \\
(0.057)\end{array}$ & $\begin{array}{r}-0.079 \\
(0.062)\end{array}$ & $\begin{array}{l}0.137^{* * *} \\
(0.035)\end{array}$ \\
\hline Managerial (F) & $\begin{array}{r}0.074 \\
(0.066)\end{array}$ & $\begin{array}{l}0.186^{* *} \\
(0.086)\end{array}$ & $\begin{array}{l}-0.051 \\
(0.186)\end{array}$ & $\begin{array}{l}0.222^{* * *} \\
(0.075)\end{array}$ \\
\hline Professional (F) & $\begin{array}{c}0.117^{*} \\
(0.070)\end{array}$ & $\begin{array}{l}0.192^{* *} \\
(0.084)\end{array}$ & $\begin{array}{r}-0.129 \\
(0.189)\end{array}$ & $\begin{array}{l}0.161^{* *} \\
(0.074)\end{array}$ \\
\hline Technical (F) & $\begin{array}{c}0.107^{*} \\
(0.063)\end{array}$ & $\begin{array}{l}0.174^{* *} \\
(0.077)\end{array}$ & $\begin{array}{c}-0.062 \\
(0.187)\end{array}$ & $\begin{array}{r}0.089 \\
(0.076)\end{array}$ \\
\hline Clerical (F) & $\begin{array}{r}0.109 \\
(0.078)\end{array}$ & $\begin{array}{c}0.177^{*} \\
(0.092)\end{array}$ & $\begin{array}{l}-0.104 \\
(0.181)\end{array}$ & $\begin{array}{l}0.176^{* *} \\
(0.088)\end{array}$ \\
\hline Sales $(F)$ & $\begin{array}{r}0.004 \\
(0.077)\end{array}$ & $\begin{array}{r}0.085 \\
(0.086)\end{array}$ & $\begin{array}{r}-0.110 \\
(0.179)\end{array}$ & $\begin{array}{r}0.101 \\
(0.077)\end{array}$ \\
\hline Craft Trade (F) & $\begin{array}{r}0.038 \\
(0.057)\end{array}$ & $\begin{array}{c}0.133^{*} \\
(0.071)\end{array}$ & $\begin{array}{l}-0.287 \\
(0.210)\end{array}$ & $\begin{array}{r}0.027 \\
(0.070)\end{array}$ \\
\hline Machine opperation (F) & $\begin{array}{r}0.039 \\
(0.057)\end{array}$ & $\begin{array}{r}0.112 \\
(0.072)\end{array}$ & $\begin{array}{l}-0.198 \\
(0.182)\end{array}$ & $\begin{array}{r}-0.102 \\
(0.073)\end{array}$ \\
\hline Elementary Occ. (F) & $\begin{array}{r}0.009 \\
(0.058)\end{array}$ & $\begin{array}{l}-0.074 \\
(0.076)\end{array}$ & $\begin{array}{l}-0.239 \\
(0.180)\end{array}$ & $\begin{array}{r}-0.023 \\
(0.079)\end{array}$ \\
\hline Armed/Military (F) & & $\begin{array}{r}0.103 \\
(0.129)\end{array}$ & & $\begin{array}{r}0.084 \\
(0.111)\end{array}$ \\
\hline Unemployed (F) & $\begin{array}{r}0.002 \\
(0.078)\end{array}$ & $\begin{array}{l}-0.195^{*} \\
(0.116)\end{array}$ & $\begin{array}{r}-0.247 \\
(0.192)\end{array}$ & $\begin{array}{c}-0.094 \\
(0.082)\end{array}$ \\
\hline Difficulties most of the time & $\begin{array}{r}0.001 \\
(0.033)\end{array}$ & $\begin{array}{r}-0.020 \\
(0.084)\end{array}$ & $\begin{array}{r}0.006 \\
(0.058)\end{array}$ & $\begin{array}{r}0.021 \\
(0.068)\end{array}$ \\
\hline Difficulties often & $\begin{array}{r}-0.003 \\
(0.031)\end{array}$ & $\begin{array}{r}0.063 \\
(0.052)\end{array}$ & $\begin{array}{l}0.012^{* * *} \\
(0.054)\end{array}$ & $\begin{array}{r}-0.038 \\
(0.054)\end{array}$ \\
\hline Difficulties occasionally & $\begin{array}{r}-0.009 \\
(0.030)\end{array}$ & $\begin{array}{r}0.026 \\
(0.023)\end{array}$ & $\begin{array}{r}0.110 \\
(0.041)\end{array}$ & $\begin{array}{r}0.033 \\
(0.026)\end{array}$ \\
\hline Difficulties never & $\begin{array}{r}0.041 \\
(0.057)\end{array}$ & $\begin{array}{r}0.041 \\
(0.051)\end{array}$ & $\begin{array}{l}0.026^{* *} \\
(0.037)\end{array}$ & $\begin{array}{r}-0.014 \\
(0.047)\end{array}$ \\
\hline Other European Union & $\begin{array}{r}0.038 \\
(0.083)\end{array}$ & $\begin{array}{l}-0.111 \\
(0.105)\end{array}$ & $\begin{array}{c}0.407^{*} \\
(0.202)\end{array}$ & $\begin{array}{r}0.094 \\
(0.061)\end{array}$ \\
\hline Other outside EU & $\begin{array}{l}-0.381^{* *} \\
(0.150)\end{array}$ & $\begin{array}{r}-0.133 \\
(0.230)\end{array}$ & $\begin{array}{l}-0.094^{* * *} \\
(0.055)\end{array}$ & $\begin{array}{l}-0.170^{* * *} \\
(0.040)\end{array}$ \\
\hline Woman & $\begin{array}{l}-0.055^{* * *} \\
(0.019)\end{array}$ & $\begin{array}{l}-0.063^{* * *} \\
(0.021)\end{array}$ & $\begin{array}{r}-0.077 \\
(0.028)\end{array}$ & $\begin{array}{l}-0.077^{* * *} \\
(0.022)\end{array}$ \\
\hline R-Squared & 0.029 & 0.082 & 0.095 & 0.085 \\
\hline
\end{tabular}


Table A4: Top: Regression coefficients of son's educational level on circumstance conditioned distribution. The omitted level is Upper Secondary (ISCED 3); Bottom: Regression coefficients of son's occupational category on the residual of the circumstance smoothed distribution after controlling for education. The ommited category is Skilled Agricultural.

Son's educational level on smoothed (circumstance conditioned) income. Regression coefficients of Equation 13

\begin{tabular}{|c|c|c|c|c|c|c|c|c|c|c|c|c|}
\hline & \multicolumn{2}{|c|}{$\mathrm{AT}$} & \multicolumn{2}{|c|}{$\mathrm{BE}$} & \multicolumn{2}{|c|}{ CY } & \multicolumn{2}{|c|}{$\mathrm{CZ}$} & \multicolumn{2}{|c|}{$\mathrm{DE}$} & \multicolumn{2}{|c|}{ DK } \\
\hline & 2004 & 2010 & 2004 & 2010 & 2004 & 2010 & 2004 & 2010 & 2004 & 2010 & 2004 & 2010 \\
\hline Constant & $\begin{array}{l}9.790^{* * *} \\
(0.006)\end{array}$ & $\begin{array}{l}9.864^{* * *} \\
(0.004)\end{array}$ & $\begin{array}{l}9.764^{* * *} \\
(0.006)\end{array}$ & $\begin{array}{l}9.804^{* * *} \\
(0.007)\end{array}$ & $\begin{array}{l}9.544^{* * *} \\
(0.007)\end{array}$ & $\begin{array}{l}9.579^{* * *} \\
(0.009)\end{array}$ & $\begin{array}{l}8.367^{* * *} \\
(0.004)\end{array}$ & $\begin{array}{l}8.802^{* * *} \\
(0.003)\end{array}$ & $\begin{array}{l}9.763^{* * *} \\
(0.001)\end{array}$ & $\begin{array}{l}9.810^{* * *} \\
(0.002)\end{array}$ & $\begin{array}{l}10.054^{* * *} \\
(0.003)\end{array}$ & $\begin{array}{l}10.107^{* * *} \\
(0.005)\end{array}$ \\
\hline Pre-Primary (ISCED 0) & & $\begin{array}{l}-0.203^{* * *} \\
(0.046)\end{array}$ & $\begin{array}{l}-0.339^{* * *} \\
(0.043)\end{array}$ & $\begin{array}{l}-0.237^{* * *} \\
(0.043)\end{array}$ & $\begin{array}{l}-0.345^{* * *} \\
(0.068)\end{array}$ & $\begin{array}{l}-0.187^{*} \\
(0.096)\end{array}$ & & & & & & \\
\hline Primary (ISCED 1) & $\begin{array}{r}-0.427 \\
(0.280)\end{array}$ & & $\begin{array}{l}-0.110^{* * *} \\
(0.014)\end{array}$ & $\begin{array}{l}-0.071^{* * *} \\
(0.023)\end{array}$ & $\begin{array}{l}-0.130^{* * *} \\
(0.015)\end{array}$ & $\begin{array}{l}-0.036^{*} \\
(0.020)\end{array}$ & & $\begin{array}{l}-0.265^{* *} \\
(0.105)\end{array}$ & $\begin{array}{l}-0.071^{* * *} \\
(0.012)\end{array}$ & $\begin{array}{l}-0.062^{* *} \\
(0.026)\end{array}$ & $\begin{array}{l}-0.206^{* * *} \\
(0.041)\end{array}$ & $\begin{array}{r}-0.021 \\
(0.127)\end{array}$ \\
\hline Low Secondary (ISCED 2) & $\begin{array}{l}-0.146^{* * *} \\
(0.013)\end{array}$ & $\begin{array}{l}-0.149^{* * *} \\
(0.010)\end{array}$ & $\begin{array}{r}0.003 \\
(0.011)\end{array}$ & $\begin{array}{l}-0.062^{* * *} \\
(0.015)\end{array}$ & $\begin{array}{l}-0.117^{* * *} \\
(0.016)\end{array}$ & $\begin{array}{r}-0.008 \\
(0.020)\end{array}$ & $\begin{array}{l}-0.176^{* * *} \\
(0.013)\end{array}$ & $\begin{array}{l}-0.066^{* * *} \\
(0.014)\end{array}$ & $\begin{array}{l}-0.026^{* * *} \\
(0.005)\end{array}$ & $\begin{array}{l}-0.065^{* * *} \\
(0.008)\end{array}$ & $\begin{array}{l}-0.023^{* * *} \\
(0.005)\end{array}$ & $\begin{array}{l}-0.022^{*} \\
(0.011)\end{array}$ \\
\hline Post Secondary (ISCED 4) & $\begin{array}{l}0.042^{* * *} \\
(0.014)\end{array}$ & $\begin{array}{l}0.049^{* * *} \\
(0.010)\end{array}$ & $\begin{array}{r}0.040 \\
(0.026)\end{array}$ & $\begin{array}{r}0.017 \\
(0.024)\end{array}$ & $\begin{array}{r}0.014 \\
(0.030)\end{array}$ & $\begin{array}{l}0.148^{* * *} \\
(0.038)\end{array}$ & $\begin{array}{l}0.092^{* * *} \\
(0.028)\end{array}$ & $\begin{array}{l}0.054^{* *} \\
(0.022)\end{array}$ & $\begin{array}{r}0.001 \\
(0.003)\end{array}$ & $\begin{array}{r}0.007 \\
(0.005)\end{array}$ & & \\
\hline Tertiary (ISCED 5 and 6) & $\begin{array}{l}0.060^{* * *} \\
(0.011)\end{array}$ & $\begin{array}{l}0.087^{* * *} \\
(0.008)\end{array}$ & $\begin{array}{l}0.072^{* * *} \\
(0.008)\end{array}$ & $\begin{array}{l}0.074^{* * *} \\
(0.009)\end{array}$ & $\begin{array}{l}0.138^{* * *} \\
(0.011)\end{array}$ & $\begin{array}{l}0.120^{* * *} \\
(0.012)\end{array}$ & $\begin{array}{l}0.103^{* * *} \\
(0.010)\end{array}$ & $\begin{array}{l}0.157^{* * *} \\
(0.006)\end{array}$ & $\begin{array}{l}0.008^{* * *} \\
(0.002)\end{array}$ & $\begin{array}{l}0.049^{* * *} \\
(0.003)\end{array}$ & $\begin{array}{l}0.014^{* * *} \\
(0.004)\end{array}$ & $\begin{array}{l}0.064^{* * *} \\
(0.008)\end{array}$ \\
\hline \multirow[t]{4}{*}{ R-squared } & 0.108 & 0.155 & 0.120 & 0.178 & 0.196 & 0.162 & 0.175 & 0.137 & 0.018 & 0.078 & 0.040 & 0.084 \\
\hline & \multicolumn{12}{|c|}{ Son's occupational category on the residual of the smoothed income after controlling for education. Regression coefficients of Equation 16} \\
\hline & \multicolumn{2}{|c|}{$\mathrm{AT}$} & \multicolumn{2}{|c|}{$\mathrm{BE}$} & \multicolumn{2}{|c|}{$\mathrm{CY}$} & \multicolumn{2}{|c|}{$\mathrm{CZ}$} & \multicolumn{2}{|c|}{$\mathrm{DE}$} & \multicolumn{2}{|c|}{ DK } \\
\hline & 2004 & 2010 & 2004 & 2010 & 2004 & 2010 & 2004 & 2010 & 2004 & 2010 & 2004 & 2010 \\
\hline Constant & $\begin{array}{r}-0.029 \\
(0.019)\end{array}$ & $\begin{array}{l}0.038^{* *} \\
(0.019)\end{array}$ & $\begin{array}{r}-0.013 \\
(0.040)\end{array}$ & $\begin{array}{r}0.057 \\
(0.053)\end{array}$ & $\begin{array}{r}0.037 \\
(0.037)\end{array}$ & $\begin{array}{l}0.125^{* * *} \\
(0.040)\end{array}$ & $\begin{array}{l}-0.052^{* *} \\
(0.024)\end{array}$ & $\begin{array}{c}0.039^{*} \\
(0.021)\end{array}$ & $\begin{array}{l}-0.043^{* * *} \\
(0.008)\end{array}$ & $\begin{array}{l}-0.042^{* * *} \\
(0.016)\end{array}$ & $\begin{array}{r}0.012 \\
(0.015)\end{array}$ & $\begin{array}{l}-0.014 \\
(0.022)\end{array}$ \\
\hline Managerial & $\begin{array}{l}0.078^{* * *} \\
(0.023)\end{array}$ & $\begin{array}{r}0.011 \\
(0.022)\end{array}$ & $\begin{array}{l}0.083^{* *} \\
(0.041)\end{array}$ & $\begin{array}{r}-0.029 \\
(0.055)\end{array}$ & $\begin{array}{r}-0.063 \\
(0.047)\end{array}$ & $\begin{array}{r}0.008 \\
(0.051)\end{array}$ & $\begin{array}{l}0.097^{* * *} \\
(0.028)\end{array}$ & $\begin{array}{r}-0.017 \\
(0.024)\end{array}$ & $\begin{array}{l}0.070^{* * *} \\
(0.010)\end{array}$ & $\begin{array}{l}0.062^{* * *} \\
(0.017)\end{array}$ & $\begin{array}{c}0.039^{* *} \\
(0.018)\end{array}$ & $\begin{array}{c}0.049^{*} \\
(0.025)\end{array}$ \\
\hline Professional & $0.084^{* * *}$ & 0.009 & 0.022 & -0.035 & 0.005 & $-0.093^{* *}$ & $0.047^{*}$ & -0.029 & $0.058^{* * *}$ & $0.061^{* * *}$ & $\begin{array}{r}-0.007 \\
-0.07\end{array}$ & 0.025 \\
\hline & $(0.022)$ & $(0.021)$ & $(0.040)$ & $(0.054)$ & (0.039) & $(0.041)$ & $(0.026)$ & $(0.022)$ & $(0.008)$ & $(0.016)$ & $(0.016)$ & $(0.023)$ \\
\hline Technical & 0.033 & -0.005 & 0.018 & -0.029 & -0.012 & $-0.088^{* *}$ & $0.081^{* * *}$ & -0.019 & $0.035^{* * *}$ & $0.029 *$ & -0.008 & 0.015 \\
\hline & $(0.020)$ & $(0.020)$ & $(0.041)$ & $(0.054)$ & (0.039) & $(0.042)$ & $(0.025)$ & $(0.022)$ & $(0.008)$ & $(0.016)$ & $(0.016)$ & $(0.023)$ \\
\hline Clerical & $0.072^{* * *}$ & 0.002 & 0.016 & -0.048 & 0.000 & $-0.107^{* *}$ & $0.046^{*}$ & $-0.052^{* *}$ & $0.026^{* * *}$ & $0.031^{*}$ & -0.004 & 0.010 \\
\hline & $(0.021)$ & $(0.021)$ & $(0.040)$ & $(0.054)$ & (0.039) & $(0.042)$ & $(0.028)$ & $(0.023)$ & (0.009) & $(0.016)$ & $(0.016)$ & $(0.024)$ \\
\hline Sales & 0.032 & $-0.049^{* *}$ & -0.009 & $-0.133^{* *}$ & -0.025 & $-0.144^{* * *}$ & 0.009 & $-0.057^{* *}$ & $0.026^{* * *}$ & 0.023 & $-0.029^{*}$ & -0.012 \\
\hline & $(0.020)$ & $(0.021)$ & $(0.041)$ & $(0.054)$ & $(0.038)$ & $(0.042)$ & $(0.026)$ & $(0.022)$ & (0.009) & $(0.016)$ & $(0.016)$ & $(0.028)$ \\
\hline Craftmanship & -0.024 & $-0.084^{* * *}$ & -0.004 & -0.025 & -0.041 & $-0.127 * * *$ & $0.075^{* * *}$ & -0.022 & $0.066^{* * *}$ & $0.072^{* * *}$ & -0.018 & 0.024 \\
\hline & $(0.021)$ & $(0.021)$ & $(0.041)$ & $(0.054)$ & $(0.039)$ & $(0.041)$ & $(0.026)$ & $(0.022)$ & $(0.009)$ & $(0.016)$ & $(0.016)$ & $(0.024)$ \\
\hline Machinery & -0.006 & $-0.117^{* * *}$ & 0.037 & -0.054 & -0.033 & $-0.086^{* *}$ & $0.054^{* *}$ & $-0.060^{* * *}$ & $0.061^{* * *}$ & $0.042^{* * *}$ & -0.024 & -0.003 \\
\hline & $(0.023)$ & $(0.022)$ & $(0.042)$ & $(0.055)$ & $(0.041)$ & $(0.044)$ & $(0.026)$ & $(0.022)$ & (0.009) & $(0.016)$ & $(0.017)$ & $(0.026)$ \\
\hline Elementary Occ. & -0.017 & $-0.115^{* * *}$ & -0.054 & $-0.160^{* * *}$ & $-0.153^{* * *}$ & $-0.256^{* * *}$ & $\begin{array}{l}-0.035 \\
-0.028)\end{array}$ & $-0.100^{* * *}$ & $0.042^{* * *}$ & $0.036^{* *}$ & -0.025 & -0.035 \\
\hline & $(0.021)$ & $(0.021)$ & $(0.041)$ & $(0.055)$ & $(0.039)$ & $(0.042)$ & $(0.028)$ & $(0.023)$ & $(0.009)_{* * *}$ & $(0.017)$ & $(0.016)$ & $(0.025)$ \\
\hline Armed Occ. & $\begin{array}{r}0.060 \\
(0.043)\end{array}$ & $\begin{array}{r}0.017 \\
(0.058)\end{array}$ & & & 0.033 & $\begin{array}{l}-0.096^{*} \\
(0.049)\end{array}$ & $\begin{array}{r}-0.036 \\
(0.080)\end{array}$ & -0.051 & $0.082^{* * *}$ & & $\begin{array}{r}-0.076 \\
(0.048)\end{array}$ & $\begin{array}{l}-0.107 \\
(0.153)\end{array}$ \\
\hline R-squared & 0.073 & 0.068 & 0.044 & 0.059 & 0.067 & 0.102 & 0.050 & 0.054 & 0.046 & 0.023 & 0.025 & 0.024 \\
\hline
\end{tabular}


Son's educational level on smoothed (circumstance conditioned) income. Regression coefficients of Equation 13

\begin{tabular}{|c|c|c|c|c|c|c|c|c|c|c|c|c|}
\hline & \multicolumn{2}{|c|}{$\mathrm{EE}$} & \multicolumn{2}{|c|}{ EL } & \multicolumn{2}{|c|}{$\mathrm{ES}$} & \multicolumn{2}{|c|}{ FI } & \multicolumn{2}{|c|}{ FR } & \multicolumn{2}{|c|}{$\mathrm{HU}$} \\
\hline & 2004 & 2010 & 2004 & 2010 & 2004 & 2010 & 2004 & 2010 & 2004 & 2010 & 2004 & 2010 \\
\hline Constant & $\begin{array}{l}8.025^{* * *} \\
(0.007)\end{array}$ & $\begin{array}{l}8.375^{* * *} \\
(0.008)\end{array}$ & $\begin{array}{l}9.205^{* * *} \\
(0.007)\end{array}$ & $\begin{array}{l}9.083^{* * *} \\
(0.009)\end{array}$ & $\begin{array}{l}9.324^{* * *} \\
(0.005)\end{array}$ & $\begin{array}{l}9.255^{* * *} \\
(0.006)\end{array}$ & $\begin{array}{l}9.840^{* * *} \\
(0.002)\end{array}$ & $\begin{array}{l}9.992^{* * * *} \\
(0.004)\end{array}$ & $\begin{array}{l}9.704^{* * *} \\
(0.003)\end{array}$ & $\begin{array}{l}9.791 * * * \\
(0.004)\end{array}$ & $\begin{array}{l}8.159^{* * *} \\
(0.004)\end{array}$ & $\begin{array}{l}8.128^{* * *} \\
(0.003)\end{array}$ \\
\hline Pre-Primary (ISCED 0) & & & & $\begin{array}{c}-0.044 \\
(0.102)\end{array}$ & & & & & $\begin{array}{l}-0.302^{* * *} \\
(0.025)\end{array}$ & $\begin{array}{l}-0.397^{* * *} \\
(0.034)\end{array}$ & $\begin{array}{l}-0.319^{* * *} \\
(0.066)\end{array}$ & \\
\hline Primary (ISCED 1) & $\begin{array}{l}-0.380^{* * *} \\
(0.084)\end{array}$ & $\begin{array}{l}-0.082 \\
(0.103)\end{array}$ & $\begin{array}{l}-0.091^{* * *} \\
(0.011)\end{array}$ & $\begin{array}{l}-0.216^{* * *} \\
(0.019)\end{array}$ & $\begin{array}{l}-0.165^{* * *} \\
(0.007)\end{array}$ & $\begin{array}{l}-0.133^{* * *} \\
(0.010)\end{array}$ & & & $\begin{array}{l}-0.111^{* * *} \\
(0.008)\end{array}$ & $\begin{array}{l}-0.137^{* * *} \\
(0.011)\end{array}$ & $\begin{array}{l}-0.428^{* * *} \\
(0.035)\end{array}$ & $\begin{array}{l}-0.168^{* * *} \\
(0.020)\end{array}$ \\
\hline Low Secondary (ISCED 2) & $\begin{array}{l}-0.085^{* * *} \\
(0.025)\end{array}$ & $\begin{array}{l}-0.067^{* * *} \\
(0.021)\end{array}$ & $\begin{array}{l}-0.061^{* * *} \\
(0.013)\end{array}$ & $\begin{array}{l}-0.153^{* * *} \\
(0.019)\end{array}$ & $\begin{array}{l}-0.103^{* * *} \\
(0.007)\end{array}$ & $\begin{array}{l}-0.033^{* * *} \\
(0.008)\end{array}$ & $\begin{array}{r}-0.008 \\
(0.005)\end{array}$ & $\begin{array}{r}-0.014 \\
(0.012)\end{array}$ & $\begin{array}{l}-0.037^{* * *} \\
(0.006)\end{array}$ & $\begin{array}{l}-0.012 \\
(0.009)\end{array}$ & $\begin{array}{l}-0.116^{* * *} \\
(0.008)\end{array}$ & $\begin{array}{l}-0.144^{* * *} \\
(0.008)\end{array}$ \\
\hline Post Secondary (ISCED 4) & $\begin{array}{r}0.029 \\
(0.018)\end{array}$ & $\begin{array}{l}-0.041 \\
(0.032)\end{array}$ & $\begin{array}{l}0.104^{* * *} \\
(0.018)\end{array}$ & $\begin{array}{l}0.093^{* * *} \\
(0.023)\end{array}$ & $\begin{array}{r}0.015 \\
(0.017)\end{array}$ & $\begin{array}{r}0.033 \\
(0.024)\end{array}$ & $\begin{array}{r}0.024 \\
(0.024)\end{array}$ & $\begin{array}{r}0.000 \\
(0.019)\end{array}$ & & $\begin{array}{r}0.007 \\
(0.036)\end{array}$ & & $\begin{array}{l}0.067^{* * *} \\
(0.011)\end{array}$ \\
\hline Tertiary (ISCED 5 and 6) & $\begin{array}{l}0.108^{* * *} \\
(0.011)\end{array}$ & $\begin{array}{l}0.157^{* * *} \\
(0.012)\end{array}$ & $\begin{array}{l}0.128^{* * *} \\
(0.011)\end{array}$ & $\begin{array}{l}0.186^{* * *} \\
(0.013)\end{array}$ & $\begin{array}{l}0.094^{* * *} \\
(0.007)\end{array}$ & $\begin{array}{l}0.122^{* * *} \\
(0.007)\end{array}$ & $\begin{array}{l}0.042^{* * *} \\
(0.003)\end{array}$ & $\begin{array}{r}0.003 \\
(0.005)\end{array}$ & $\begin{array}{l}0.077^{* * *} \\
(0.005)\end{array}$ & $\begin{array}{l}0.087^{* * *} \\
(0.005)\end{array}$ & $\begin{array}{l}0.136^{* * *} \\
(0.008)\end{array}$ & $\begin{array}{l}0.193^{* * *} \\
(0.006)\end{array}$ \\
\hline R-squared & 0.073 & 0.063 & 0.143 & 0.219 & 0.213 & 0.143 & 0.069 & 0.000 & 0.152 & 0.150 & 0.217 & 0.251 \\
\hline
\end{tabular}

Son's occupational category on the residual of the smoothed income after controlling for education. Regression coefficients of Equation 16

\begin{tabular}{|c|c|c|c|c|c|c|c|c|c|c|c|c|}
\hline & \multicolumn{2}{|c|}{$\mathrm{EE}$} & \multicolumn{2}{|c|}{ EL } & \multicolumn{2}{|c|}{ ES } & \multicolumn{2}{|c|}{ FI } & \multicolumn{2}{|c|}{ FR } & \multicolumn{2}{|c|}{$\mathrm{HU}$} \\
\hline & 2004 & 2010 & 2004 & 2010 & 2004 & 2010 & 2004 & 2010 & 2004 & 2010 & 2004 & 2010 \\
\hline Constant & $\begin{array}{l}-0.061^{* *} \\
(0.031)\end{array}$ & $\begin{array}{l}-0.115^{* * *} \\
(0.035)\end{array}$ & $\begin{array}{l}-0.046^{* * *} \\
(0.014)\end{array}$ & $\begin{array}{l}-0.014 \\
(0.020)\end{array}$ & $\begin{array}{l}-0.097^{* * *} \\
(0.014)\end{array}$ & $\begin{array}{l}-0.062^{* * *} \\
(0.016)\end{array}$ & $\begin{array}{l}-0.020^{* *} \\
(0.008)\end{array}$ & $\begin{array}{r}-0.012 \\
(0.018)\end{array}$ & $\begin{array}{l}-0.046^{* * *} \\
(0.010)\end{array}$ & $\begin{array}{r}-0.009 \\
(0.014)\end{array}$ & $\begin{array}{l}-0.087^{* * *} \\
(0.017)\end{array}$ & $\begin{array}{l}-0.053^{* * *} \\
(0.014)\end{array}$ \\
\hline Managerial & $\begin{array}{l}0.112^{* * *} \\
(0.033)\end{array}$ & $\begin{array}{l}0.174^{* * *} \\
(0.038)\end{array}$ & $\begin{array}{l}0.122^{* * *} \\
(0.021)\end{array}$ & $\begin{array}{l}0.066^{* *} \\
(0.028)\end{array}$ & $\begin{array}{l}0.159^{* * *} \\
(0.018)\end{array}$ & $\begin{array}{l}0.039 * * \\
(0.019)\end{array}$ & $\begin{array}{l}0.028^{* * * *} \\
(0.009)\end{array}$ & $\begin{array}{l}0.065^{* * *} \\
(0.020)\end{array}$ & $\begin{array}{l}0.081 \text { *** } \\
(0.012)\end{array}$ & $\begin{array}{l}0.035^{* *} \\
(0.016)\end{array}$ & $\begin{array}{l}0.103^{* * * *} \\
(0.019)\end{array}$ & $\begin{array}{l}0.074^{* * *} \\
(0.018)\end{array}$ \\
\hline Professional & $\begin{array}{c}0.084^{* *} \\
(0.033)\end{array}$ & $\begin{array}{l}0.120^{* * *} \\
(0.037)\end{array}$ & $\begin{array}{l}0.089^{* * *} \\
(0.018)\end{array}$ & $\begin{array}{c}0.056^{* *} \\
(0.024)\end{array}$ & $\begin{array}{l}0.151^{* * *} \\
(0.016)\end{array}$ & $\begin{array}{l}0.115^{* * *} \\
(0.017)\end{array}$ & $\begin{array}{l}0.059^{* * *} \\
(0.009)\end{array}$ & $\begin{array}{l}0.038^{* *} \\
(0.019)\end{array}$ & $\begin{array}{l}0.074^{* * *} \\
(0.012)\end{array}$ & $\begin{array}{l}0.039^{* *} \\
(0.015)\end{array}$ & $\begin{array}{l}0.105^{* * * *} \\
(0.019)\end{array}$ & $\begin{array}{l}0.075^{* * *} \\
(0.016)\end{array}$ \\
\hline Technical & $\begin{array}{c}0.059^{*} \\
(0.034)\end{array}$ & $\begin{array}{l}0.130^{* * *} \\
(0.037)\end{array}$ & $\begin{array}{l}0.081^{* * *} \\
(0.019)\end{array}$ & $\begin{array}{r}0.030 \\
(0.027)\end{array}$ & $\begin{array}{l}0.145^{* * *} \\
(0.016)\end{array}$ & $\begin{array}{l}0.139^{* * *} \\
(0.018)\end{array}$ & $\begin{array}{r}0.007 \\
(0.009)\end{array}$ & $\begin{array}{c}-0.014 \\
(0.019)\end{array}$ & $\begin{array}{l}0.061^{* * *} \\
(0.011)\end{array}$ & $\begin{array}{l}0.030^{* *} \\
(0.015)\end{array}$ & $\begin{array}{l}0.110^{* * *} \\
(0.019)\end{array}$ & $\begin{array}{l}0.077^{* * * *} \\
(0.016)\end{array}$ \\
\hline Clerical & $\begin{array}{r}0.061 \\
(0.038)\end{array}$ & $\begin{array}{l}0.096^{* *} \\
(0.040)\end{array}$ & $\begin{array}{l}0.111^{* * *} \\
(0.018)\end{array}$ & $\begin{array}{r}0.034 \\
(0.024)\end{array}$ & $\begin{array}{l}0.115^{* * *} \\
(0.016)\end{array}$ & $\begin{array}{l}0.107^{* * *} \\
(0.018)\end{array}$ & $\begin{array}{l}0.027^{* * *} \\
(0.010)\end{array}$ & $\begin{array}{l}-0.024 \\
(0.022)\end{array}$ & $\begin{array}{l}0.038^{* * *} \\
(0.012)\end{array}$ & $\begin{array}{r}-0.022 \\
(0.015)\end{array}$ & $\begin{array}{l}0.114^{* * *} \\
(0.020)\end{array}$ & $\begin{array}{l}0.068^{* * *} \\
(0.017)\end{array}$ \\
\hline Sales & $\begin{array}{r}0.002 \\
(0.034)\end{array}$ & $\begin{array}{r}0.050 \\
(0.039)\end{array}$ & $\begin{array}{l}0.057^{* * *} \\
(0.018)\end{array}$ & $\begin{array}{r}0.004 \\
(0.024)\end{array}$ & $\begin{array}{l}0.071^{* * *} \\
(0.016)\end{array}$ & $\begin{array}{l}0.051^{* * *} \\
(0.017)\end{array}$ & $\begin{array}{r}0.008 \\
(0.009)\end{array}$ & $\begin{array}{r}0.005 \\
(0.019)\end{array}$ & $\begin{array}{l}0.033^{* * *} \\
(0.012)\end{array}$ & $\begin{array}{r}-0.018 \\
(0.016)\end{array}$ & $\begin{array}{l}0.108^{* * *} \\
(0.019)\end{array}$ & $\begin{array}{l}0.049^{* * *} \\
(0.016)\end{array}$ \\
\hline Craftmanship & $\begin{array}{l}0.078^{* *} \\
(0.033)\end{array}$ & $\begin{array}{l}0.168^{* * *} \\
(0.037)\end{array}$ & $\begin{array}{l}-0.008 \\
(0.017)\end{array}$ & $\begin{array}{l}-0.047^{*} \\
(0.025)\end{array}$ & $\begin{array}{l}0.077^{* * *} \\
(0.015)\end{array}$ & $\begin{array}{r}0.016 \\
(0.017)\end{array}$ & $\begin{array}{r}-0.006 \\
(0.009)\end{array}$ & $\begin{array}{r}0.010 \\
(0.020)\end{array}$ & $\begin{array}{l}0.034^{* * *} \\
(0.012)\end{array}$ & $\begin{array}{r}-0.001 \\
(0.015)\end{array}$ & $\begin{array}{l}0.074^{* * *} \\
(0.018)\end{array}$ & $\begin{array}{l}0.044^{* * * *} \\
(0.015)\end{array}$ \\
\hline Machinery & $\begin{array}{c}0.058^{*} \\
(0.033)\end{array}$ & $\begin{array}{r}0.059 \\
(0.038)\end{array}$ & $\begin{array}{r}-0.007 \\
(0.020)\end{array}$ & $\begin{array}{r}0.022 \\
(0.029)\end{array}$ & $\begin{array}{l}0.109^{* * *} \\
(0.016)\end{array}$ & $\begin{array}{l}0.038^{* *} \\
(0.018)\end{array}$ & $\begin{array}{l}0.022^{* *} \\
(0.010)\end{array}$ & $\begin{array}{r}0.007 \\
(0.022)\end{array}$ & $\begin{array}{l}0.048^{* * *} \\
(0.012)\end{array}$ & $\begin{array}{r}-0.005 \\
(0.016)\end{array}$ & $\begin{array}{l}0.070^{* * *} \\
(0.019)\end{array}$ & $\begin{array}{l}0.045^{* * *} \\
(0.016)\end{array}$ \\
\hline Elementary Occ. & -0.002 & 0.050 & -0.030 & $-0.092^{* * *}$ & $0.036^{* *}$ & 0.007 & -0.013 & $\begin{array}{l}-0.023 \\
(0.025)\end{array}$ & 0.003 & $-0.028^{*}$ & $0.048^{* *}$ & 0.025 \\
\hline Armed Occ. & $\begin{array}{c}(0.035) \\
0.224^{* * *} \\
(0.078)\end{array}$ & $\begin{array}{l}(0.043) \\
0.223^{* * *} \\
(0.064)\end{array}$ & $\begin{array}{l}(0.021) \\
-0.080^{*} \\
(0.048)\end{array}$ & $\begin{array}{l}(0.027) \\
0.122^{* * *} \\
(0.038)\end{array}$ & $\begin{array}{l}(0.015) \\
0.188^{* * *} \\
(0.028)\end{array}$ & $\begin{array}{l}(0.017) \\
0.145^{* * *} \\
(0.035)\end{array}$ & $\begin{array}{l}(0.011) \\
0.127^{* * *} \\
(0.018)\end{array}$ & $\begin{array}{r}(0.025) \\
0.006 \\
(0.085)\end{array}$ & $\begin{array}{l}(0.012) \\
0.091 \text { *** } \\
(0.020)\end{array}$ & $\begin{array}{l}(0.016) \\
0.093^{* * *} \\
(0.022)\end{array}$ & $\begin{array}{l}(0.019) \\
0.156^{* * *} \\
(0.031)\end{array}$ & $\begin{array}{l}(0.016) \\
0.061^{* *} \\
(0.027)\end{array}$ \\
\hline R-squared & 0.036 & 0.045 & 0.062 & 0.066 & 0.052 & 0.062 & 0.069 & 0.052 & 0.034 & 0.039 & 0.028 & 0.019 \\
\hline
\end{tabular}

Table A4.B 
Son's educational level on smoothed (circumstance conditioned) income. Regression coefficients of Equation 13

\begin{tabular}{|c|c|c|c|c|c|c|c|c|c|c|c|c|}
\hline & \multicolumn{2}{|c|}{ IE } & \multicolumn{2}{|c|}{ IS } & \multicolumn{2}{|c|}{ IT } & \multicolumn{2}{|c|}{ LT } & \multicolumn{2}{|c|}{$\mathrm{LU}$} & \multicolumn{2}{|c|}{ LV } \\
\hline & 2004 & 2010 & 2004 & 2010 & 2004 & 2010 & 2004 & 2010 & 2004 & 2010 & 2004 & 2010 \\
\hline Constant & $9.867^{* * *}$ & $9.845^{* * *}$ & $10.039^{* * *}$ & $9.317^{* * *}$ & $9.626^{* * *}$ & $9.539 * * *$ & $7.633^{* * *}$ & $7.937^{* * *}$ & $10.347^{* * *}$ & $10.238^{* * *}$ & $7.690^{* * *}$ & $7.919^{* * *}$ \\
\hline Pre-Primary (ISCED 0) & & & & & $\begin{array}{l}(0.004) \\
-0.366^{* * *} \\
(0.025)\end{array}$ & $\begin{array}{l}-0.463^{* * *} \\
(0.032)\end{array}$ & & $\begin{array}{r}(0.009) \\
(0.064 \\
(0.149)\end{array}$ & & & $\begin{array}{r}-0.107 \\
(0.152)\end{array}$ & $\begin{array}{r}(0.006) \\
-0.188 \\
(0.184)\end{array}$ \\
\hline Primary (ISCED 1) & $\begin{array}{l}-0.099^{* * *} \\
(0.014)\end{array}$ & $\begin{array}{l}-0.095^{* * *} \\
(0.021)\end{array}$ & $\begin{array}{l}-0.116^{*} \\
(0.065)\end{array}$ & & $\begin{array}{l}-0.224^{* * *} \\
(0.009)\end{array}$ & $\begin{array}{l}-0.171^{* * *} \\
(0.012)\end{array}$ & $\begin{array}{r}0.156 \\
(0.205)\end{array}$ & $\begin{array}{r}-0.001 \\
(0.084)\end{array}$ & $\begin{array}{l}-0.263^{* * *} \\
(0.014)\end{array}$ & $\begin{array}{l}-0.227^{* * *} \\
(0.011)\end{array}$ & $\begin{array}{l}-0.061 * * * \\
(0.022)\end{array}$ & $\begin{array}{l}-0.174^{* *} \\
(0.071)\end{array}$ \\
\hline Low Secondary (ISCED 2) & $\begin{array}{l}-0.049^{* * *} \\
(0.012)\end{array}$ & $\begin{array}{r}-0.008 \\
(0.016)\end{array}$ & $\begin{array}{l}-0.013 \\
(0.015)\end{array}$ & $\begin{array}{r}0.010 \\
(0.017)\end{array}$ & $\begin{array}{l}-0.118^{* * *} \\
(0.005)\end{array}$ & $\begin{array}{l}-0.092^{* * *} \\
(0.005)\end{array}$ & $\begin{array}{l}-0.099^{* * *} \\
(0.025)\end{array}$ & $\begin{array}{l}-0.043^{* *} \\
(0.020)\end{array}$ & $\begin{array}{l}-0.092^{* * *} \\
(0.018)\end{array}$ & $\begin{array}{l}-0.051^{* * *} \\
(0.015)\end{array}$ & $\begin{array}{r}-0.036 \\
(0.027)\end{array}$ & $\begin{array}{l}-0.045^{* * *} \\
(0.013)\end{array}$ \\
\hline Post Secondary (ISCED 4) & $\begin{array}{r}0.016 \\
(0.015)\end{array}$ & $\begin{array}{l}-0.050^{* *} \\
(0.021)\end{array}$ & $\begin{array}{l}0.075^{* * *} \\
(0.020)\end{array}$ & $\begin{array}{l}-0.028 \\
(0.019)\end{array}$ & $\begin{array}{l}0.022^{* *} \\
(0.009)\end{array}$ & $\begin{array}{l}0.069^{* * *} \\
(0.011)\end{array}$ & $\begin{array}{l}-0.011 \\
(0.014)\end{array}$ & $\begin{array}{r}-0.008 \\
(0.013)\end{array}$ & $\begin{array}{r}0.031 \\
(0.026)\end{array}$ & $\begin{array}{c}0.049^{*} \\
(0.027)\end{array}$ & $\begin{array}{l}0.049^{* * *} \\
(0.018)\end{array}$ & $\begin{array}{l}0.052^{* * *} \\
(0.018)\end{array}$ \\
\hline Tertiary (ISCED 5 and 6) & $\begin{array}{l}0.126^{* * *} \\
(0.011)\end{array}$ & $\begin{array}{l}0.129^{* * *} \\
(0.013)\end{array}$ & $\begin{array}{l}0.085^{* * * *} \\
(0.013)\end{array}$ & $\begin{array}{c}0.023^{*} \\
(0.013)\end{array}$ & $\begin{array}{l}0.156^{* * * *} \\
(0.006)\end{array}$ & $\begin{array}{l}0.132^{* * *} \\
(0.006)\end{array}$ & $\begin{array}{l}0.170^{* * *} \\
(0.014)\end{array}$ & $\begin{array}{l}0.129^{* * * *} \\
(0.011)\end{array}$ & $\begin{array}{l}0.121^{* * * *} \\
(0.013)\end{array}$ & $\begin{array}{l}0.193^{* * *} \\
(0.010)\end{array}$ & $\begin{array}{l}0.190^{* * *} \\
(0.013)\end{array}$ & $\begin{array}{l}0.136^{* * *} \\
(0.009)\end{array}$ \\
\hline R-squared & 0.166 & 0.149 & 0.070 & 0.005 & 0.208 & 0.202 & 0.101 & 0.063 & 0.271 & 0.211 & 0.144 & 0.111 \\
\hline
\end{tabular}

Son's occupational category on the residual of the smoothed income after controlling for education. Regression coefficients of Equation 16



Table A4.C 
Son's educational level on smoothed (circumstance conditioned) income. Regression coefficients of Equation 13

\begin{tabular}{|c|c|c|c|c|c|c|c|c|c|c|c|c|}
\hline & \multicolumn{2}{|c|}{$\mathrm{NE}$} & \multicolumn{2}{|c|}{ NO } & \multicolumn{2}{|c|}{$\mathrm{PL}$} & \multicolumn{2}{|c|}{$\mathrm{PO}$} & \multicolumn{2}{|c|}{$\mathrm{SE}$} & \multicolumn{2}{|c|}{ SI } \\
\hline & 2004 & 2010 & 2004 & 2010 & 2004 & 2010 & 2004 & 2010 & 2004 & 2010 & 2004 & 2010 \\
\hline Constant & $\begin{array}{l}9.810^{* * *} \\
(0.003)\end{array}$ & $\begin{array}{l}9.899 * * * \\
(0.003)\end{array}$ & $\begin{array}{l}10.225^{* * *} \\
(0.003)\end{array}$ & $\begin{array}{l}10.361^{* * *} \\
(0.005)\end{array}$ & $\begin{array}{l}7.766^{* * * *} \\
(0.003)\end{array}$ & $\begin{array}{l}8.328^{* * *} \\
(0.003)\end{array}$ & $\begin{array}{l}9.091 * * * \\
(0.014)\end{array}$ & $\begin{array}{l}9.118^{* * * *} \\
(0.011)\end{array}$ & $\begin{array}{l}9.825^{* * *} \\
(0.003)\end{array}$ & $9.930^{* * *}$ & $\begin{array}{l}9.107^{* * *} \\
(0.003)\end{array}$ & $9.201^{* * *}$ \\
\hline Pre-Primary (ISCED 0) & & $\begin{array}{l}-0.087^{* *} \\
(0.041)\end{array}$ & $\begin{array}{r}0.029 \\
(0.049)\end{array}$ & & $\begin{array}{l}-0.216^{* * *} \\
(0.047)\end{array}$ & $\begin{array}{l}-0.198^{* *} \\
(0.086)\end{array}$ & & & & & & $(0.004)$ \\
\hline Primary (ISCED 1) & $\begin{array}{l}-0.054^{* * *} \\
(0.013)\end{array}$ & $\begin{array}{l}-0.078^{* * *} \\
(0.017)\end{array}$ & & & $\begin{array}{l}-0.122^{\text {*** }} \\
(0.008)\end{array}$ & $\begin{array}{l}-0.098^{* * *} \\
(0.010)\end{array}$ & $\begin{array}{l}-0.270^{* * *} \\
(0.016)\end{array}$ & $\begin{array}{l}-0.260^{* * *} \\
(0.013)\end{array}$ & $\begin{array}{l}-0.283^{* * *} \\
(0.030)\end{array}$ & $(0.004)$ & $\begin{array}{l}-0.060^{* * *} \\
(0.007)\end{array}$ & $\begin{array}{l}-0.091 \text { *** } \\
(0.028)\end{array}$ \\
\hline Low Secondary (ISCED 2) & $\begin{array}{l}-0.035^{* * *} \\
(0.006)\end{array}$ & $\begin{array}{l}-0.022^{* * *} \\
(0.005)\end{array}$ & $\begin{array}{r}0.001 \\
(0.015)\end{array}$ & $\begin{array}{c}-0.004 \\
(0.008)\end{array}$ & & & $\begin{array}{l}-0.086^{* * *} \\
(0.020)\end{array}$ & $\begin{array}{l}-0.114^{* * *} \\
(0.015)\end{array}$ & $\begin{array}{r}-0.010 \\
(0.008)\end{array}$ & $\begin{array}{r}-0.017 \\
(0.012)\end{array}$ & $\begin{array}{l}-0.064^{* * *} \\
(0.019)\end{array}$ & $\begin{array}{l}-0.068^{* * *} \\
(0.010)\end{array}$ \\
\hline Post Secondary (ISCED 4) & $\begin{array}{r}0.005 \\
(0.012)\end{array}$ & $\begin{array}{l}-0.018^{*} \\
(0.010)\end{array}$ & $\begin{array}{r}0.016 \\
(0.013)\end{array}$ & $\begin{array}{r}0.019 \\
(0.016)\end{array}$ & $\begin{array}{l}0.129^{* * *} \\
(0.012)\end{array}$ & $\begin{array}{l}0.150^{* * *} \\
(0.011)\end{array}$ & $\begin{array}{r}-0.075 \\
(0.116)\end{array}$ & $\begin{array}{r}0.105 \\
(0.073)\end{array}$ & $\begin{array}{l}0.028^{* * * *} \\
(0.008)\end{array}$ & $\begin{array}{r}-0.005 \\
(0.008)\end{array}$ & $\begin{array}{l}0.066^{* * *} \\
(0.010)\end{array}$ & \\
\hline Tertiary (ISCED 5 and 6) & $\begin{array}{l}0.032^{* * *} \\
(0.004)\end{array}$ & $\begin{array}{l}0.056^{* * *} \\
(0.004)\end{array}$ & $\begin{array}{l}0.040^{* * *} \\
(0.005)\end{array}$ & $\begin{array}{l}0.065^{* * *} \\
(0.007)\end{array}$ & $\begin{array}{r}0.241 \\
(0.006)\end{array}$ & $\begin{array}{l}0.177^{* * *} \\
(0.005)\end{array}$ & $\begin{array}{l}0.175^{* * *} \\
(0.020)\end{array}$ & $\begin{array}{l}0.154^{* * *} \\
(0.015)\end{array}$ & $\begin{array}{l}0.038^{* * *} \\
(0.005)\end{array}$ & $\begin{array}{r}-0.003 \\
(0.005)\end{array}$ & $\begin{array}{l}0.142^{* * *} \\
(0.007)\end{array}$ & $\begin{array}{l}0.102^{* * *} \\
(0.006)\end{array}$ \\
\hline R-squared & 0.063 & 0.155 & 0.039 & 0.111 & 0.204 & 0.210 & 0.313 & 0.283 & 0.087 & 0.008 & 0.198 & 0.150 \\
\hline
\end{tabular}

Son's occupational category on the residual of the smoothed income after controlling for education. Regression coefficients of Equation 16

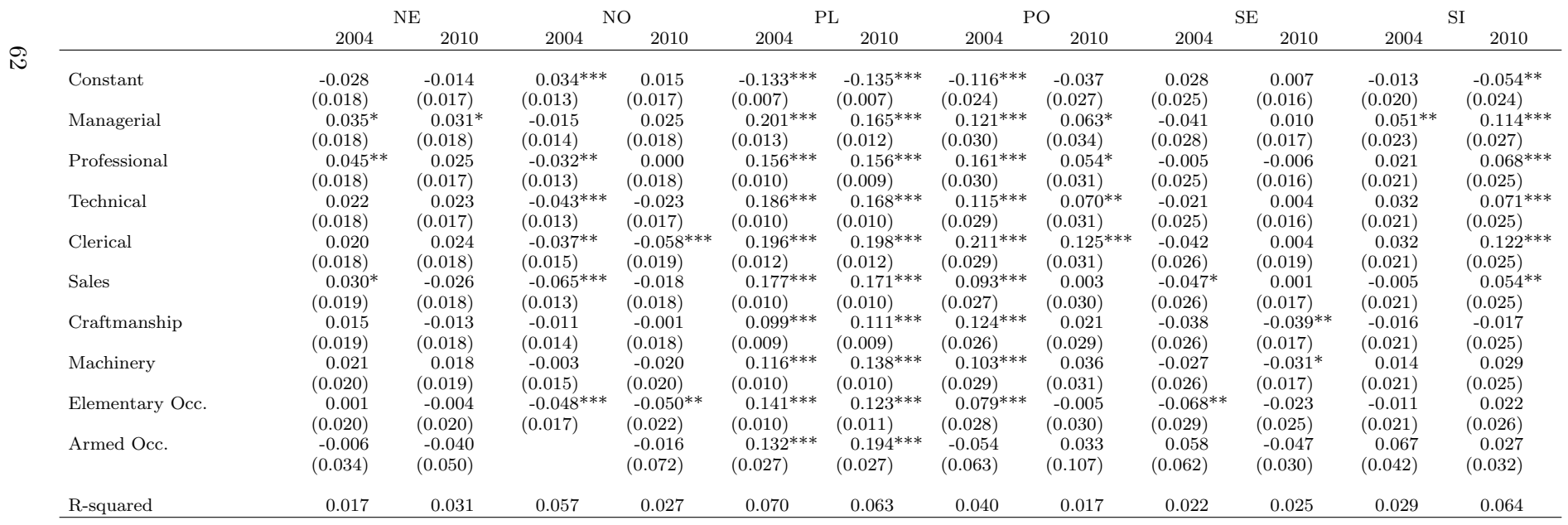

Table A4.D 


\begin{tabular}{|c|c|c|c|c|}
\hline & \multicolumn{2}{|c|}{ SK } & \multicolumn{2}{|c|}{ UK } \\
\hline $\begin{array}{l}\text { Constant } \\
\text { Pre-Primary (ISCED 0) }\end{array}$ & $\begin{array}{c}7.930^{* * *} \\
-(0.002)\end{array}$ & $\begin{array}{c}8.591^{* * *} \\
-(0.004)\end{array}$ & $\begin{array}{l}10.026^{* * *} \\
-(0.007)\end{array}$ & $\begin{array}{l}9.712^{* * *} \\
-(0.005)\end{array}$ \\
\hline \multicolumn{5}{|l|}{ Primary (ISCED 1) } \\
\hline $\begin{array}{l}\text { Low Secondary (ISCED 2) } \\
\text { Post Secondary (ISCED 4) } \\
\text { Tertiary (ISCED } 5 \text { and } 6 \text { ) }\end{array}$ & $\begin{array}{c}-0.048^{* * *} \\
-(0.007) \\
\\
0.031^{* * *} \\
-(0.004)\end{array}$ & $\begin{array}{c}-0.122^{* * *} \\
-(0.018) \\
0.047^{* *} \\
-(0.022) \\
0.118^{* * *} \\
-(0.007)\end{array}$ & $\begin{array}{c}-0.124^{* * *} \\
-(0.016) \\
-0.063^{* *} \\
-(0.027) \\
0.083^{* * *} \\
-(0.010)\end{array}$ & $\begin{array}{c}-0.144^{* * *} \\
-(0.012) \\
-0.214^{* * *} \\
-(0.055) \\
0.049^{* * *} \\
-(0.006)\end{array}$ \\
\hline R-squared & 0.042 & 0.128 & 0.109 & 0.110 \\
\hline \multicolumn{5}{|c|}{ Son's occupational category on the residual of the smoothed income after controlling for education. Regression coefficients of Equation 16} \\
\hline & \multicolumn{2}{|c|}{ SK } & $2004^{\mathrm{U}}$ & $\begin{array}{l}\text { K } \\
\quad 2010 \\
\end{array}$ \\
\hline Constant & $\begin{array}{r}-0.009 \\
(0.023)\end{array}$ & $\begin{array}{r}0.031 \\
(0.028)\end{array}$ & $\begin{array}{r}0.014 \\
(0.066)\end{array}$ & $\begin{array}{c}0.067^{*} \\
(0.035)\end{array}$ \\
\hline Managerial & $\begin{array}{r}0.036 \\
(0.024)\end{array}$ & $\begin{array}{r}0.005 \\
(0.031)\end{array}$ & $\begin{array}{r}0.038 \\
(0.067)\end{array}$ & $\begin{array}{r}-0.016 \\
(0.036)\end{array}$ \\
\hline Professional & $\begin{array}{r}0.015 \\
(0.024)\end{array}$ & $\begin{array}{r}-0.029 \\
(0.030)\end{array}$ & $\begin{array}{r}0.032 \\
(0.067)\end{array}$ & $\begin{array}{r}-0.043 \\
(0.036)\end{array}$ \\
\hline Technical & $\begin{array}{r}0.025 \\
(0.023)\end{array}$ & $\begin{array}{r}-0.021 \\
(0.029)\end{array}$ & $\begin{array}{r}-0.008 \\
(0.067)\end{array}$ & $\begin{array}{r}-0.047 \\
(0.036)\end{array}$ \\
\hline Clerical & $\begin{array}{r}-0.022 \\
(0.024)\end{array}$ & $\begin{array}{r}-0.025 \\
(0.030)\end{array}$ & $\begin{array}{r}-0.063 \\
(0.067)\end{array}$ & $\begin{array}{l}-0.079^{* *} \\
(0.036)\end{array}$ \\
\hline Sales & $\begin{array}{l}-0.012 \\
(0.024)\end{array}$ & $\begin{array}{r}-0.038 \\
(0.029)\end{array}$ & $\begin{array}{r}-0.058 \\
(0.067)\end{array}$ & $\begin{array}{l}-0.130^{* * *} \\
(0.036)\end{array}$ \\
\hline Craftmanship & $\begin{array}{r}0.015 \\
(0.023)\end{array}$ & $\begin{array}{r}-0.031 \\
(0.029)\end{array}$ & $\begin{array}{r}0.013 \\
(0.068)\end{array}$ & $\begin{array}{l}-0.068^{*} \\
(0.037)\end{array}$ \\
\hline Machinery & $\begin{array}{r}0.012 \\
(0.024)\end{array}$ & $\begin{array}{r}-0.039 \\
(0.029)\end{array}$ & $\begin{array}{r}-0.028 \\
(0.068)\end{array}$ & $\begin{array}{l}-0.137^{* * *} \\
(0.037)\end{array}$ \\
\hline Elementary Occ. & $\begin{array}{r}-0.037 \\
(0.024)\end{array}$ & $\begin{array}{l}-0.093^{* * *} \\
(0.031)\end{array}$ & $\begin{array}{r}-0.058 \\
(0.068)\end{array}$ & $\begin{array}{l}-0.101 * * * \\
(0.036)\end{array}$ \\
\hline Armed Occ. & & $\begin{array}{r}-0.063 \\
(0.047)\end{array}$ & & \\
\hline R-squared & 0.030 & 0.009 & 0.045 & 0.075 \\
\hline
\end{tabular}

